\title{
Ecosystem Ecology
}

\section{Temporal variability in ${ }^{13} \mathrm{C}$ of respired $\mathrm{CO}_{2}$ in a pine and a hardwood forest subject to similar climatic conditions}

\author{
Behzad Mortazavi1 $^{\square}$, Jeffrey P. Chanton${ }^{1}$, James L. Prater ${ }^{1}$, A. Christopher Oishi ${ }^{2}$, Ram Oren² and Gabriel Katul ${ }^{2}$ \\ (1) Department of Oceanography, Florida State University, Tallahassee, FL 32306-4320, USA \\ (2) Nicholas School of the Environment and Earth Sciences, Duke University, LSRC, Box 90328, Durham, NC 27708-0328, USA
}

Behzad Mortazavi

Email: mortazavi@ocean.fsu.edu

Phone: +1-850-6454639

Fax: $+1-850-6442581$

Received: 13 January 2004 Accepted: 14 July 2004 Published online: 31 August 2004

\begin{abstract}
Temporal variability in the ${ }^{13} \mathrm{C}$ of foliage $\left(\delta{ }^{13} \mathrm{C}_{\mathrm{F}}\right)$, soil $\left(\delta^{13} \mathrm{C}_{\mathrm{S}}\right)$ and ecosystem $\left(\delta 13 \mathrm{C}_{\mathrm{R}}\right)$ respired $\mathrm{CO}_{2}$ was contrasted between a $17.2-\mathrm{m}$ tall evenly aged loblolly pine forest and a $35-\mathrm{m}$ tall unevenly aged mature second growth mixed broadleaf deciduous forest in North Carolina, USA, over a 2-year period. The two forests are located at the Duke Forest within a kilometer of each other and are subject to identical climate and have similar soil types. The $\delta 13 \mathrm{C}_{\mathrm{F}}$, collected just prior to dawn, was primarily controlled by the time-lagged vapor pressure deficit (VPD) in both stands; it was used for calculating the ratio of intercellular to ambient $\mathrm{CO}_{2}(\mathrm{Ci} / \mathrm{Ca})$. A remarkable similarity was observed in the relationship between $\mathrm{Ci} / \mathrm{Ca}$ and time-lagged VPD in these two forests despite large differences in hydraulic characteristics. This similarity emerged as a result of physiological adjustments that compensated for differences in plant hydraulic characteristics, as predicted by a recently proposed equilibrium hypothesis, and has implications to ecophysiological models. We found that in the broadleaf forest, the $\delta{ }^{13} \mathrm{C}$ of forest floor $\mathrm{CO}_{2}$ efflux dominated the $\delta{ }^{13} \mathrm{C}_{\mathrm{R}}$, while in the younger pine forest, the $\delta{ }^{13} \mathrm{C}$ of foliage respired $\mathrm{CO}_{2}$ dominated $\delta{ }^{13} \mathrm{C}_{\mathrm{R}}$. This dependence resulted in a more variable ${ }^{113} \mathrm{C}_{\mathrm{R}}$ in the pine forest when compared to the broadleaf forest due to the larger photosynthetic contribution. Given the sensitivity of the atmospheric inversion models to $\delta{ }^{13} \mathrm{C}_{\mathrm{R}}$, the results demonstrate that these models could be improved by accounting for stand characteristics, in addition to previously recognized effects of moisture availability, when estimating $\delta 13 \mathrm{C}_{\mathrm{R}}$
\end{abstract}

Keywords Carbon isotope - Coniferous forest - Hardwood forest - Vapor pressure deficit - Ecosystem respiration

\section{Introduction}

Partitioning the exchange of $\mathrm{CO}_{2}$ between the biosphere and the atmosphere requires detailed understanding of the roles of the terrestrial and oceanic environments in the uptake and release of $\mathrm{CO}_{2}$. Stable isotopes of $\mathrm{CO}_{2}\left({ }^{13} \mathrm{C},{ }^{18} \mathrm{O}\right)$ and $\mathrm{CO}_{2}$ concentrations have been used in the analysis of the global carbon cycle by inversion of atmospheric transport models (Ciais 
et al. $1995 a$; Randerson et al. 2002) to partition the global $\mathrm{CO}_{2}$ sink into the oceanic and terrestrial components. The atmospheric inversion models rely on estimates of photosynthetic discrimination $(\Delta)$ and the ${ }^{13} \mathrm{C}$ of ecosystem-respired $\mathrm{CO}_{2}\left({ }^{13} \mathrm{C}_{\mathrm{R}}\right)$ (Tans et al. $\underline{1993}$; Fung et al. 1997) to assess variations in the magnitude of the terrestrial carbon sink. $\Delta$ can be determined at the leaf level (Evans et al. 1986; Harwood et al. 1993; Gillon and Yakir 2000) and at the ecosystem level (Yakir and Sternberg 2000; Bowling et al. 2001; Buchmann and Kaplan 2001; Conte and Weber 2002). Whole ecosystem discrimination can be determined from the isotopic composition of $\mathrm{CO}_{2}$ in the convective boundary layer, which includes the effects of respiration, photosynthesis and turbulent transport (Lloyd et al. 1996). A recent approach uses the isotopic composition of ablated leaf waxes to determine discrimination at the continental scale (Conte and Weber 2002). On the global scale, $\Delta$ and $\delta{ }^{13} \mathrm{C}_{\mathrm{R}}$ are not measured directly and must be estimated from physiological-climate models (e.g., Lloyd and Farquhar 1994; Fung et al. 1997) or from atmospheric data (Bakwin et al. 1998) to which large corrections are applied to remove the isotopic imprint of anthropogenic sources.

Investigations at the ecosystem scale (e.g., Bowling et al. 2002) indicate that $\Delta$ and ${ }^{13} \mathrm{C}_{\mathrm{R}}$ do not remain constant, but reflect the consequences of changes in environmental factors on photosynthetic and respiratory processes. Interannual variability in $\Delta$ and $\delta{ }^{13} \mathrm{C}_{\mathrm{R}}$ caused by nutrient stress, changes in $\mathrm{C}_{3} / \mathrm{C}_{4}$ productivity, or ENSO induced droughts (Hoerling and Kumar 2003), would be interpreted by inversion models as a shift in the terrestrial and oceanic sinks (Randerson et al. 2002). The variability in these two parameters will alter the conclusions about the timing and nature of the terrestrial carbon sink (Bowling et al. 2002). Fung et al. (1997) indicate that a $3 \%$ overestimate in the global value of $\Delta$ would result in a $20 \%$ underestimate in the magnitude of the biospheric sink.

Evidence for variability in $\delta{ }^{13} \mathrm{C}_{\mathrm{R}}$ in response to changes in environmental factors (Pataki et al. $\underline{2003}$ ) such as vapor pressure deficit (VPD), precipitation, and soil moisture has been investigated for coniferous forest of the Northwest Pacific (Bowling et al. 2002; Fessenden and Ehleringer 2002, 2003), in a Florida pine plantation (Mortazavi and Chanton 2002a), and in the tropical forest of the Amazon basin (Ometto et al. 2002). The ${ }^{813} \mathrm{C}_{\mathrm{R}}$ has been found to be ${ }^{13} \mathrm{C}$ enriched during drier weather because of reduced stomatal conductance and lower photosynthetic discrimination (Bowling et al. 2002; Fessenden and Ehleringer 2002; Mortazavi and Chanton 2002a). Because of the sensitivity of global atmospheric inversion models to $\delta{ }^{13} \mathrm{C}_{\mathrm{R}}$, these models should begin to incorporate the shifts in $\delta{ }^{13} \mathrm{C}_{\mathrm{R}}$ based upon variations in moisture and stand characteristics (Ehleringer et al. 2002).

Northern mid-latitude forests are a large terrestrial carbon sink (Ciais et al. $\underline{19956}$; Schimel $\underline{1995}$; Houghton et al. $\underline{1998}$; Tans and White 1998). In south-eastern USA, the young pine forests appear to be among the largest atmospheric terrestrial carbon sinks with published annual net ecosystem carbon exchange (NEE) values among the highest when compared to other published NEE values in Europe and North America (Wofsy et al. 1993; Hollinger et al. 1994; Clark et al. 1999; Valentini et al. 2000; Lai et al. 2002). These young pine forests are interlaced with second growth mature deciduous forests. The stands within the forest mosaic differ in characteristics such as age, tree height and their ability to assimilate $\mathrm{CO}_{2}$ (Clark et al. 1999). To date, separating the effects of climatic conditions and soil type on carbon isotope discrimination from plant physiologic and hydraulic properties remains a challenge.

The objectives of this study were to investigate variations in the carbon isotope composition of ecosystem respiration ( $\left.{ }^{13} \mathrm{C}_{\mathrm{R}}\right)$ and two of its main components, foliage respiration $\left(\delta 13 \mathrm{C}_{\mathrm{F}}\right)$ and soil respiration $\left(\delta^{13} \mathrm{C}_{\mathrm{S}}\right)$ at two AmeriFlux sites in the Duke Forest of North Carolina, USA which were subject to identical climatic conditions: a maturing pine forest and an older, taller deciduous broadleaf forest. Tree height, through its control on stomatal conductance (Schäfer et al. 2000) influences variations in $\Delta$, which is reflected in $\delta{ }^{13} \mathrm{C}_{\mathrm{R}}$ (Bowling et al. 2002). To avoid potentially damaging effects of declining leaf water potential, stomatal conductance declines with tree height (Schäfer et al. $\underline{2000}$ ).

Because of hydraulic constraint and its impact on stomatal conductance we hypothesized that ${ }^{13} \mathrm{C}$ enriched values of foliage respired $\mathrm{CO}_{2}\left(\delta^{13} \mathrm{C}_{\mathrm{F}}\right)$ and foliage organic matter $\left(\delta^{13} \mathrm{C}_{\mathrm{P}}\right)$ would be measured at the taller deciduous forest. We also 
hypothesized that because of lower assimilation rates (Ryan and Yoder 1997; P. Stoy et al., unpublished data) and higher soil $\mathrm{CO}_{2}$ fluxes (Palmroth et al., unpublished data) at the older forest, the ${ }^{13} \mathrm{C}$ of ecosystem respired $\mathrm{CO}_{2}$ would exhibit lower variability compared to the younger pine forest in response to changes in water availability. This would result from the relatively higher contribution of soil respired ${ }^{13} \mathrm{CO}_{2}$ to ${ }^{813} \mathrm{C}_{\mathrm{R}}$, which would buffer changes in $\delta 13 \mathrm{C}_{\mathrm{R}}$ (Mortazavi and Chanton 2002a).

To determine the variability in $\delta{ }^{13} \mathrm{C}_{\mathrm{F}}, \delta{ }^{13} \mathrm{C}_{\mathrm{P}}$ and $\delta{ }^{13} \mathrm{C}_{\mathrm{R}}$ for southeastern USA forests composed of different stands, we measured $\delta^{13} \mathrm{C}_{\mathrm{F}}$ from foliage collected before dawn, collected foliage for $\delta^{13} \mathrm{C}_{\mathrm{P}}$ and sampled canopy air from which nighttime $\delta{ }^{13} \mathrm{C}_{\mathrm{R}}$ values were determined. Soil $\mathrm{CO}_{2}$ fluxes and ${ }^{13} \mathrm{C}_{\mathrm{S}}$ were also determined with static chambers at both stands. The broader objective of this effort is to provide guidance for dealing with a forest mosaic for inverse atmospheric models that use stable isotopes to constrain regional sources and sinks.

\section{Materials and methods}

\section{Study site}

The study sites are located in the Blackwood Division of Duke Forest in Orange County, $\left(35^{\circ} 58^{\prime} 41.430^{\prime \prime} \mathrm{N}, 79^{\circ} 05^{\prime} 39.087^{\prime}\right.$

'W), near Durham, N.C., USA. The 90-ha pine forest is a 17.2-m tall even-aged stand and was established from 3-year seedlings following clear-cutting and burning of the site in 1983. Loblolly pines (Pinus taeda, L.) from a Piedmont provenance were planted at $2 \times 2.4 \mathrm{~m}$ spacing. Density of co-dominant pines in the study portion of the stand is approximately 1,600 trees ha ${ }^{-1}$. The hardwood forest is a $35-\mathrm{m}$ tall unevenly aged mature second growth deciduous hardwood mix. The oldest individuals exceed 180 years. The distance between the two towers is $986 \mathrm{~m}$. The two stands have very distinct leaf area index (LAI) profiles in terms of leaf area density distribution near the top of the canopy. The LAI peak is at normalized height $(z / h)$ of 0.8 and 0.6 for the hardwood and pine, respectively (Katul et al. 1997).

\section{Weather and climate data}

Mean air temperature and relative humidity were measured with Vaisala sensors (HMP35C, Campbell Scientific, Logan, Utah, USA) at two-third the canopy height. Soil moisture content was measured with four CS 615 sensors (Campbell Scientific) at the pine forest and 12 sensors at the hardwood forests. At the pine forest, the sensors measured the depthintegrated soil moisture across a 30-cm distance. At the hardwood forest, six sensors measured soil moisture at the 5-15-cm depth and six sensors measured soil moisture at the 20-25-cm depth. The outputs from the 12 sensors were used to calculate mean soil moisture at the hardwood site. Oren et al. (1998) showed that $30 \mathrm{~cm}$ is sufficiently deep to encompass the root volume active in water uptake. Data were sampled every $1 \mathrm{~min}$ and averaged over a 30-min period.

\section{Protocols for sample collection}

\section{${ }^{13} \mathrm{C}$ of foliage respired $\mathrm{CO}_{2}$}

Foliage was collected just before dawn and put into vials and capped with Belco stoppers, which have been shown to be inert with respect to ${ }^{13} \mathrm{C}$ and ${ }^{18} \mathrm{O}$ of $\mathrm{CO}_{2}$ (Mortazavi and Chanton 2002b). The measurements were timed to follow a long period of darkness to minimize the effects of isotopic fractionation, which may be associated with leaf respiration (Ghashghaie et al. 2001, 2003; Duranceau et al. 1999; Tcherkez et al. 2003).

Pine foliage was clipped from several branches. At the hardwood forest mid- canopy foliage was collected with the shotgun method. Three bottles were filled with 12 pine needles and three to five leaves from the hardwood species. Before adding the foliage to the vial, each vial was flushed with background air collected from above the canopy. This background air was 
analyzed for $\mathrm{CO}_{2}$ concentration and ${ }^{13} \mathrm{C}$ as described below. After a 20 -min dark incubation period at the ambient temperature, the bottles were put on ice. Our objective was to use the shortest incubation time that would yield sufficient respired $\mathrm{CO}_{2}(5,000-10,000 \mathrm{ppmv})$ to make the background values inconsequential. Bottles were then brought to the laboratory where they were frozen and analyzed within 2 weeks of sample collection.

The $\delta{ }^{13} \mathrm{C}$ of the vial headspace results from a combination of $\mathrm{CO}_{2}$ respired by the foliage and a small amount of background $\mathrm{CO}_{2}$ in the vial. A mass balance equation can be used to estimate ${ }^{13} \mathrm{C}_{\mathrm{F}}$ :

$C_{\mathrm{V}}=C_{\mathrm{B}}+C_{\mathrm{F}}$

$\delta^{13} \mathrm{C}_{\mathrm{V}} \times C_{\mathrm{V}}=\delta^{13} \mathrm{C}_{\mathrm{B}} \times C_{\mathrm{B}}+\delta^{13} \mathrm{C}_{\mathrm{F}} \times C_{\mathrm{F}}$

where $C_{\mathrm{V}}, C_{\mathrm{B}}$ and $C_{\mathrm{F}}$ correspond to the vial headspace, background $\mathrm{CO}_{2}$ concentration and $\mathrm{CO}_{2}$ produced by foliage respiration. $\delta{ }^{13} \mathrm{C}_{\mathrm{V}}, \delta{ }^{13} \mathrm{C}_{\mathrm{B}}$, and $\delta{ }^{13} \mathrm{C}_{\mathrm{F}}$ correspond to the ${ }^{13} \mathrm{C}$ ratio of vial headspace, background, and foliage respired $\mathrm{CO}_{2}$. With Eqs. 1 and $\underline{2}$ and from measurement of the vial headspace and background $\mathrm{CO}_{2}$ concentrations and isotopic ratios, $\delta{ }^{13} \mathrm{C}_{\mathrm{F}}$ can be solved for.

Precision of the method was estimated in November 2001. Foliage from a selected pine branch was collected and combined. Foliage subsample were then placed in five separate vials for determination of $\delta^{13} \mathrm{C}_{\mathrm{F}}$. Foliage collected from the same branch yielded a standard deviation (SD) of $0.34 \%$. On March 2002, we compared the bottle incubation procedure for determination of $\delta^{13} \mathrm{C}_{\mathrm{F}}$ with a closed loop and vial system similar to that described by Fessenden and Ehleringer (2003), and results between the two methods were not significantly different (B. Mortazavi et al, unpublished data) . Additional comparisons between the foliage-vial technique and approaches for measuring the $\delta^{13} \mathrm{C}_{\mathrm{F}}$ with Mylar balloons and leaf chambers to enclose whole branches have also shown agreement within $0.6 \pm 0.5 \%$ (J. Prater and J. Chanton, unpublished data).

\section{Foliage ${ }^{13} \mathrm{C}$}

The carbon isotopic composition of leaves was determined for samples collected before dawn. At the pine plantation, needles from mid canopy and top of the canopy from several branches were collected and pooled. At the hardwood site, samples from several trees were collected with the shotgun method and pooled. All organic matter was dried at $60^{\circ} \mathrm{C}$, ground to a fine powder and analyzed for ${ }^{13} \mathrm{C}$ on an isotope ratio mass spectrometer (IRMS) coupled to a CHN analyzer. Measurement precision for all organic matter was $\sim 0.2 \%$. Data are presented as means and the $1 / 2$ range of variability on duplicate measurements.

\section{Tower profiles}

Nighttime air samples were collected between 2 and 4 a.m. local time. At the pine forest, nighttime samples were collected within the canopy at $0.01,0.5,2,5$, and $10 \mathrm{~m}$ and above the canopy at $23 \mathrm{~m}$ above the ground. At the hardwood site nighttime air samples were collected within the canopy at $0.01,0.5,9,20 \mathrm{~m}$ and above the canopy at $42 \mathrm{~m}$ above the ground. Duplicate daytime samples were also collected at local noontime from the tops of the towers. During the first two 
visits to the site, samples were only collected at one location (Pine forest: November 2000 and Hardwood forest: February 2001). During subsequent visits samples were collected during the same night at both locations, except in March 2002 at the hardwood site, when the $\mathrm{CO}_{2}$ gradient was $<20 \mathrm{ppm}$ and canopy air samples were not collected. At both sites, the entire air sample collection time lasted $<0.5 \mathrm{~h}$. Samples were collected with a bellows pump, passed through a magnesium perchlorate trap to remove $\mathrm{H}_{2} \mathrm{O}$ vapor and pressurized into pre-evacuated Summa canisters (Biospheric Research) (Mortazavi and Chanton 2002b) . Ecosystem respired $\delta{ }^{13} \mathrm{CO}_{2}$ were determined by the geometric linear regression (Keeling plots) applied to the nighttime tower $\mathrm{CO}_{2}$ isotope ratios and their respective $1 / \mathrm{CO}_{2}$ concentrations (Pataki et al. 2003).

\section{Soil flux}

Soil $\mathrm{CO}_{2}$ fluxes were measured within $<12 \mathrm{~h}$ of the tower sampling with replicate static chambers placed within $5 \mathrm{~m}$ of each other at both forests. The chambers were $65 \times 65 \mathrm{~cm}$ and enclosed a volume of 1021 , including the collar base. The collars were inserted into the soil to a depth of $2 \mathrm{~cm}$ and were placed permanently at the site during the initial visit. A fan inside the chamber gently circulated the air. Replicate gas samples $(125 \mathrm{ml})$ from the chamber headspace were drawn with a syringe and stored in pre-evacuated glass vials with Belco stoppers for later analysis (Mortazavi and Chanton 2002b). Samples were collected at time 0 and every 15 min during a 45-min period for $\mathrm{CO}_{2}$ concentration determination and isotopic analysis. During the sample withdrawal a sample port on the opposite side of the collection port was left open to the atmosphere to avoid pressure fluctuations. An in-line magnesium perchlorate trap was used to remove $\mathrm{H}_{2} \mathrm{O}$ vapor when collecting headspace samples from the chambers. Samples were analyzed for $\mathrm{CO}_{2}$ concentration and isotopic composition within a week of collection. Previous investigation has shown that the sample integrity is preserved within the time frame of the analysis (Mortazavi and Chanton 2002b). $\mathrm{CO}_{2}$ concentrations increased linearly from background levels to approximately $1,000 \mathrm{ppm}$ during the entire sample collection period. Soil respired $\delta 13 \mathrm{CO}_{2}$ was determined by the geometric linear regression (Keeling plots) applied to the chamber headspace $\mathrm{CO}_{2}$ isotopic ratios and their respective $1 / \mathrm{CO}_{2}$ concentrations .

\section{Analysis}

The ${ }^{13} \mathrm{C}$ of $\mathrm{CO}_{2}$ for samples collected along the tower and from the soil $\mathrm{CO}_{2}$ flux chambers was determined with a gas chromatograph isotope ratio mass spectrometer (GC-IRMS) (Gas Chromatograph: Hewlett Packard 5890 Series II, IRMS: Finnigan Delta $\mathrm{S}$ ) operating in continuous flow mode. We applied a simple modification to a commercially available GCIRMS for rapid and precise determination of the stable isotopes $\left({ }^{13} \mathrm{C}\right.$ and $\left.{ }^{18} \mathrm{O}\right)$ of $\mathrm{CO}_{2}$ at ambient $\mathrm{CO}_{2}$ concentration. For a full description of the method see Mortazavi and Chanton (2002b). The GC was equipped with a Chromopack (Raritan, N. J., USA) Poroplot Q column (27.5-m long with a 2.5-m particle trap) to separate $\mathrm{N}_{2} \mathrm{O}$ from $\mathrm{CO}_{2}$ and was operated at an oven temperature of $25^{\circ} \mathrm{C}$. Transfer of the GC effluent to the MS was through a deactivated glass capillary.

The isotopic ratio of $\mathrm{CO}_{2}$ in foliage bottles following the 20-min incubations was determined from $0.2 \mathrm{ml}$ injections of headspace $\mathrm{CO}_{2}$ into the GC-IRMS. The isotopic ratio of the background air $\mathrm{CO}_{2}$ used to flush the bottles was determined as previously described for tower samples. The $\mathrm{CO}_{2}$ concentrations of the headspace $\mathrm{CO}_{2}$ after the incubation was determined with a LI-COR 6200 (LI-COR, Lincoln, Neb., USA) according to the procedures described by Davidson and Trumbore (1995). A volume of $100 \mu_{1}$ of the headspace gas samples were injected into a $\mathrm{CO}_{2}$ free air stream that carried the sample into a mixing chamber $(150 \mathrm{ml})$ placed inline before the LI-COR 6200. The peak height was recorded and used to determine the $\mathrm{CO}_{2}$ concentrations. A volume of $100 \mu_{1}$ to $1 \mathrm{ml}$ of certified $1 \% \mathrm{CO}_{2}$ were used to generate a calibration curve. The coefficient of variations for replicate injection of standard gases was less than $1 \% . \mathrm{CO}_{2}$ concentrations in the headspace following the incubation increased to between 1 and $2 \%$. The initial $\mathrm{CO}_{2}$ concentration of the background air used to flush the incubation bottles and the tower samples was determined with a LI-COR 6200. The LI-COR was calibrated with a NOAA reference gas $(369 \mathrm{ppm})$. The $\mathrm{CO}_{2}$ concentration from the soil $\mathrm{CO}_{2}$ flux chambers samples were determined from the $\mathrm{CO}_{2}$ voltage obtained from the GC-IRMS (Mortazavi and Chanton 2002b). A plot of $\mathrm{CO}_{2}$ concentrations determined from the voltage versus $\mathrm{CO}_{2}$ concentrations determined with the LI-COR 6200 resulted in a slope $(0.99 \pm 0.02)$ that was not 
significantly different from unity ( $t$-test, $p<0.05$, Mortazavi and Chanton $\underline{2002 b})$.

Isotopic ratios data are presented in the $\delta$ notation, and are reported relative to V-PDB. External precision for isotopic measurements was \pm 0.2 based on repeated measurements of a laboratory-working standard.

\section{Results}

\section{Environmental conditions}

Our sampling strategy covered the wide range in environmental conditions that occur at this site. Precipitation averages $1,151 \mathrm{~mm}$ annually and is well distributed throughout the year. July and August are normally the wettest months with an average of $118 \mathrm{~mm}$ of rainfall per month. October and November are normally the driest with an average of $80 \mathrm{~mm}$ of rainfall per month. Air temperatures at the site ranged from $7.86^{\circ} \mathrm{C}$ in February 2001 to a maximum of $26.16^{\circ} \mathrm{C}$ in July 2002 (Table 1). Air temperatures and VPD at the two sites were similar with the maximum difference measured at the two sites of $1.68^{\circ} \mathrm{C}$ in March 2002 and $0.21 \mathrm{kPa}$ in August 2001 (Table 1). Minimum soil moisture content was measured in November 2001 at the hardwood forest, while maximum soil moisture was measured in February of 2001 at the pine forest (Table 1 ). VPD and soil moisture values varied during the study period by a factor of 9.77 and 2.39, respectively (Table 1 ).

Table 1 Environmental conditions at the pine and hardwood forests prior to sampling for nighttime $\mathrm{CO}_{2}$ concentration and isotopic measurements. Soil moisture was measured with four and 12 sensors at the pine and hardwood forest, respectively. All data are half hourly averages for the week prior to sampling except VPD values, which represent daytime averages (net radiation $>0 \mathrm{~W} \mathrm{~m}^{-2}$ ) for days 3 and 4 prior to sampling. ND no data

\begin{tabular}{|c|c|c|c|c|c|c|c|c|}
\hline \multirow{2}{*}{ Month } & \multicolumn{2}{|c|}{ Air temperature $\left({ }^{\circ} \mathbf{C}\right)$} & \multicolumn{2}{|c|}{ VPD (kPa) } & \multicolumn{2}{|c|}{ Soil temperature $\left({ }^{\circ} \mathbf{C}\right)$} & \multicolumn{2}{|c|}{ Soil moisture $\left(\mathrm{m}^{3} \mathrm{~m}^{-3}\right)$} \\
\hline & Pine & Hardwood & Pine & Hardwood & Pine & Hardwood & Pine & Hardwood \\
\hline 15 Nov 2000 & 11.92 & 13.13 & $\mid 0.69$ & 0.81 & 11.92 & 13.13 & 0.141 & ND \\
\hline $21 \mathrm{Feb} 2001$ & 7.86 & 8.19 & 0.52 & 0.51 & 7.86 & 8.19 & 0.326 & 0.327 \\
\hline 12 Jun 2001 & 22.35 & 22.82 & 0.70 & 0.89 & 22.35 & 22.82 & 0.227 & 0.242 \\
\hline 29 Aug 2001 & 22.85 & 23.49 & 1.07 & 1.28 & 22.85 & 23.49 & 0.172 & 0.156 \\
\hline 27 Nov 2001 & 9.94 & 11.74 & 0.23 & 0.37 & 9.94 & 11.74 & 0.141 & 0.143 \\
\hline 15 Mar 2002 & 10.45 & 8.77 & 0.47 & 0.50 & 10.44 & 8.77 & 0.289 & 0.386 \\
\hline $10 \mathrm{Jul} 2002$ & 25.85 & 26.16 & 2.01 & 1.98 & 25.85 & 26.16 & 0.131 & 0.146 \\
\hline 5 Sep 2002 & 19.79 & 19.07 & 0.21 & 0.35 & 19.78 & 19.07 & 0.283 & 0.329 \\
\hline
\end{tabular}

\section{Carbon isotope ratios of organic pools and respired $\mathrm{CO}_{2}$}

The range of variability in $\delta{ }^{13} \mathrm{C}_{\mathrm{P}}$ was greater at the pine when compared to the hardwood forest (Table 2 ). $\delta{ }^{13} \mathrm{C}_{\mathrm{P}}$ values compared for the same time periods were similar at both locations (Table 2). The most enriched $\delta{ }^{13} \mathrm{C}_{\mathrm{P}}$ values at the pine stand were measured in July 2002, when soil moisture was minimum (Table 1 ). The temporal variability in $\delta 13 \mathrm{C}_{\mathrm{F}}$ at both stands exceeded the variability in $\delta{ }^{13} \mathrm{C}_{\mathrm{P}}$ (Table 2). The variability in $\delta{ }^{13} \mathrm{C}_{\mathrm{F}}$ for the same time periods was greater at the pine compared to the hardwood stand. There was a greater range of variations in ${ }^{13} \mathrm{C}_{\mathrm{F}}$ than in $\delta{ }^{13} \mathrm{C}_{\mathrm{P}}$ between any two- 
time points. For example, from July 2002 to September $2002, \delta{ }^{13} \mathrm{C}_{\mathrm{F}}$ varied by 2.1 and $2.8 \%$, while $\delta 13 \mathrm{C}_{\mathrm{P}}$ varied by 0.4 and $1.3 \%$ at the hardwood and pine stands, respectively (Table 2).

Table $2{ }^{13} \mathrm{C}$ of ecosystem- $\left(\delta^{13} \mathrm{C}_{\mathrm{R}}\right)$, soil $\left(\delta^{13} \mathrm{C}_{\mathrm{S}}\right)$ and foliage-respired $\left(\delta^{13} \mathrm{C}_{\mathrm{F}}\right) \mathrm{CO}_{2}$ and foliage organic matter $\left(\delta 13 \mathrm{C}_{\mathrm{P}}\right)$ at the hardwood and pine forest in North Carolina. $\delta{ }^{13} \mathrm{C}_{\mathrm{R}}(\% 0)$ and $\delta{ }^{13} \mathrm{C}_{\mathrm{F}}(\% 0)$ and $\delta{ }^{13} \mathrm{C}_{\mathrm{P}}\left({ }^{\%}\right)$ were determined from samples collected at nighttime. ${ }^{8}{ }^{13} \mathrm{C}_{\mathrm{S}}(\% 0)$ was determined within $12 \mathrm{~h}$ of the tower sampling

\begin{tabular}{|c|c|c|c|c|c|c|c|c|}
\hline \multirow{2}{*}{ Date } & \multicolumn{2}{|l|}{$\delta{ }^{13} \mathbf{C}_{\mathbf{R}}$} & \multicolumn{2}{|l|}{$\delta{ }^{13} \mathbf{C}_{\mathbf{S}}$} & \multicolumn{2}{|l|}{$\delta{ }^{13} \mathbf{C}_{\mathbf{F}}$} & \multicolumn{2}{|l|}{$\delta \mathbf{1 3}_{\mathbf{P}}$} \\
\hline & Hardwood & Pine & Hardwood & Pine & Hardwood & Pine & Hardwood & Pine \\
\hline 15 Nov 2000 & - & $-28.9 \pm 1.3$ & - & $-27.0 \pm 1.6$ & - & $-28.7 \pm 0.7$ & - & $-28.9 \pm 1.2$ \\
\hline 21 Feb 2001 & $-24.3 \pm 1.5$ & - & $-26.0 \pm 0.5$ & - & - & - & - & - \\
\hline 12 Jun 2001 & $-26.8 \pm 0.3$ & $-28.8 \pm 1.2$ & $-25.8 \pm 0.2$ & $-26.4 \pm 0.2$ & $-27.6 \pm 0.1$ & $-28.9 \pm 0.5$ & $-27.8 \pm 0.7$ & $-29.2 \pm 0.8$ \\
\hline 29 Aug 2001 & $-26.5 \pm 0.3$ & $-27.0 \pm 0.4$ & $-25.4 \pm 0.2$ & $-27.0 \pm 0.3$ & - & - & $-28.1 \pm 0.6$ & $-29.6 \pm 0.7$ \\
\hline 27 Nov 2001 & $-26.8 \pm 0.1$ & $-26.9 \pm 0.4$ & $-26.5 \pm 0.3$ & $-26.7 \pm 0.1$ & - & $-31.0 \pm 1.1$ & - & $-29.2 \pm 0.6$ \\
\hline 15 Mar 2002 & - & $-31.0 \pm 1.4$ & $-25.9 \pm 0.3$ & $-27.7 \pm 0.4$ & - & $-29.9 \pm 0.6$ & - & $-29.7 \pm 0.5$ \\
\hline $10 \mathrm{Jul} 2002$ & $-26.0 \pm 0.3$ & $-26.4 \pm 0.4$ & $-26.2 \pm 0.1$ & $-25.7 \pm 0.5$ & $-27.2 \pm 1.4$ & $-27.3 \pm 0.4$ & $-28.7 \pm 0.5$ & $-27.7 \pm 1.2$ \\
\hline 5 Sep 2002 & $-27.0 \pm 0.5$ & $-29.7 \pm 0.7$ & $-27.3 \pm 0.3$ & $-27.7 \pm 0.1$ & $-29.3 \pm 1.1$ & $-30.1 \pm 0.8$ & $-29.1 \pm 0.8$ & $-29.0 \pm 0.9$ \\
\hline
\end{tabular}

We used the Keeling plot approach (Keeling 1958 ) to determine ${ }^{113} \mathrm{C}_{\mathrm{R}}$ from nighttime measurement of $\mathrm{CO}_{2}$ concentrations and isotopic ratios. ${ }^{13} \mathrm{C}_{\mathrm{R}}$ at the pine forest varied from $-31.0 \%$ in March 2002 to $-26.4 \%$ in July 2002 (Table 2). ${ }^{113} \mathrm{C}_{\mathrm{R}}$ at the hardwood forest was ${ }^{13} \mathrm{C}$ enriched during the growing season, on average, by $1.4 \% 0$ relative to $\delta 13 \mathrm{C}_{\mathrm{R}}$ at the pine forest for the same time periods (Table 2). The maximum change in $\delta{ }^{13} \mathrm{C}_{\mathrm{R}}$ occurred from November 2001 to March 2002 at the pine forest (4.6\% , Table 2) and from July 2002 to September 2002 (1\%o, Table 2) at the hardwood forest.

Mean ${ }^{13} \mathrm{C}_{\mathrm{S}}$ values were $-26.2 \pm 0.8 \%$ and $-26.9 \pm 1.8 \%$ at the hardwood and pine plantations (Table 2 ). The variability in $\delta{ }^{13} \mathrm{C}_{\mathrm{S}}$ was less than the variability in $\delta{ }^{13} \mathrm{C}_{\mathrm{R}}$ and $\delta{ }^{13} \mathrm{C}_{\mathrm{S}}$ was generally enriched relative to $\delta{ }^{13} \mathrm{C}_{\mathrm{R}}$ (Table 2). The most enriched $\delta{ }^{13} \mathrm{C}_{\mathrm{S}}$ values were measured in August 2001 at the hardwood site and in July 2002 at the pine stand. From July 2002 to September $2002, \delta{ }^{13} \mathrm{C}_{\mathrm{S}}$ varied by 2.0 and $1.1 \%$ at the pine and hardwood forest, respectively (Table 2 ). During the same time period, ${ }^{13} \mathrm{C}_{\mathrm{R}}$ varied by 1.0 and $3.3 \%$ at the hardwood and pine stands, respectively (Table $\underline{2}$ ). In February 2001 and November $2001, \delta{ }^{13} \mathrm{C}_{\mathrm{R}}$ and $\delta{ }^{13} \mathrm{C}_{\mathrm{S}}$ were measured at the hardwood forest, when foliage was absent (Table 2). In November $2001 \delta^{13} \mathrm{C}_{\mathrm{S}}$ and $\delta{ }^{13} \mathrm{C}_{\mathrm{R}}$ were nearly identical, while a larger difference was observed in February 2001 (Table 2).

\section{Variability in $\delta{ }^{13} \mathrm{C}_{\mathbf{F}}, \delta{ }^{13} \mathrm{C}_{\mathbf{P}}, \delta{ }^{13} \mathrm{C}_{\mathbf{S}}$ and $\delta{ }^{13} \mathrm{C}_{\mathbf{R}}$ in response to VPD and soil moisture}

There was an increase in $\delta{ }^{13} \mathrm{C}_{\mathrm{F}}$ with increasing VPD at both locations (Fig. 1a). Here, VPD is the average daytime (net 
radiation $>0.0 \mathrm{~W} \mathrm{~m}^{-2}$ ) VPD corresponding to days 3 and 4 prior to nighttime sampling. This time lag was selected as that which provides highest correlation between the isotopic composition of respired $\mathrm{CO}_{2}$ and VPD, after Bowling et al. (2002). For example, the correlation coefficient between ${ }^{13} \mathrm{C}_{\mathrm{F}}$ and VPD increased from 0.55 (for VPD for the day prior to sampling) to 0.77 (for VPD two days prior to sampling), and to 0.88 for average VPD for days 3 and 4 prior to sampling. Beyond this time period the correlation decayed.

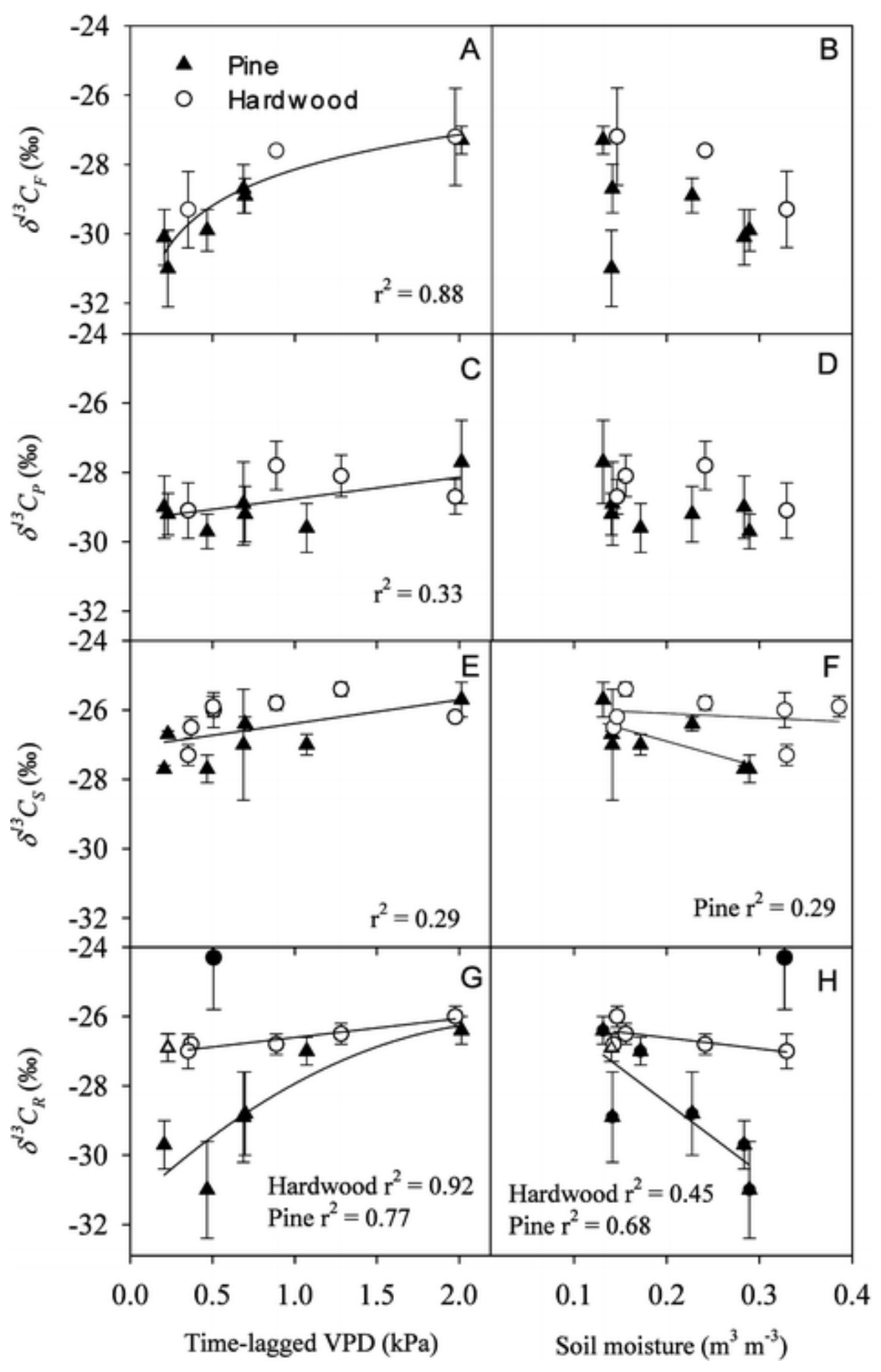

Fig. 1 a ${ }^{13} \mathrm{C}_{\mathrm{F}}$ (mean $\pm \mathrm{SD}$ ) versus time lagged daytime (net radiation $>0 \mathrm{~W} \mathrm{~m}^{-2}$ ) VPD (average of daytime VPD for days 3 and 4 prior to sampling) for the pine and hardwood forest $\left(\delta^{13} \mathrm{C}_{\mathrm{F}}=-28.1466 \times \mathrm{VPD}-0.0523\right)$. b $\delta{ }^{13} \mathrm{C}_{\mathrm{F}}$ (mean $\pm \mathrm{SD}$ ) versus soil moisture for 1 week prior to sampling at the two stands. $\mathbf{c}{ }^{13} \mathrm{C}_{\mathrm{P}}$ (mean $\pm \mathrm{SD}$ ) versus time lagged daytime VPD (average of daytime VPD for days 3 and 4 
prior to sampling) for the pine and hardwood forest. $\mathbf{d} \delta{ }^{13} \mathrm{C}_{\mathrm{P}}$ (mean $\pm \mathrm{SD}$ ) versus soil moisture for 1 week prior to sampling. e $\delta{ }^{13} \mathrm{C}_{\mathrm{S}}$ (mean $\pm 1 / 2$ range in variability) versus time lagged daytime VPD (average of daytime VPD for days 3 and 4 prior to sampling) for the pine and hardwood forest. $\mathbf{f} \delta{ }^{13} \mathrm{C}_{\mathrm{S}}$ (mean $\pm 1 / 2$ range in variability) versus soil moisture (theta) for 1 week prior to sampling at the two stands. $\mathbf{g} \delta 13 \mathrm{C}_{\mathrm{R}}$ versus time lagged daytime VPD (average of daytime VPD for days 3 and 4 prior to sampling) for the hardwood ( $\left.{ }^{13} \mathrm{C}_{\mathrm{R}}=-27.153+0.548 \times \mathrm{VPD}\right)$, the value corresponding to the time the foliage was absent (closed circle) was excluded from the regression and pine forest $\left({ }^{13} C_{R}=-31.443+4.425 \times V P D-0.919 \times V P D 2\right)$, the value corresponding to the freeze event (open triangle) was excluded from the regression. $\mathbf{h} \delta{ }^{13} \mathrm{C}_{\mathrm{R}}$ versus soil moisture (theta $)$ for 1 week prior to sampling at the hardwood $\left(\delta{ }^{13} \mathrm{C}_{\mathrm{R}}=-\right.$ 25.969-3.202 $\times$ theta, , the value corresponding to the time the foliage was absent (closed circle) was excluded from the regression and at the pine forest $\left({ }^{13} \mathrm{C}_{\mathrm{R}}=-24.458-20.134 \times\right.$ theta $)$, the value corresponding to the freeze event (open triangle) was excluded from the regression

In contrast to Fig. 1a, there was no relation between $\delta{ }^{13} \mathrm{C}_{\mathrm{F}}$ and soil moisture (Fig. $\underline{1 b}$ ). There was a mild increase in $\delta{ }^{13} \mathrm{C}_{\mathrm{P}}$ with time-lagged VPD as well (Fig. 1c), but no clear pattern was present with soil moisture (Fig. 1d). There was minor variability in $\delta{ }^{13} \mathrm{C}_{\mathrm{S}}$ with time-lagged VPD (Fig. 1e) and soil moisture (Fig. 1f). Mikan et al. (2000) radiolabled Populus trees and found peak activity in soil ${ }^{14} \mathrm{C}$ after 3-4 day. This corresponds well to our time lag.

The relation between $\delta{ }^{13} \mathrm{C}_{\mathrm{R}}$ and time-lagged VPD for the two forest types exhibited distinct patterns with a greater range of variability in $\delta{ }^{13} \mathrm{C}_{\mathrm{R}}$ for the pine forest compared to the hardwood forest (Fig. $1 \mathrm{~g}$ ). At the hardwood forest, $\delta{ }^{13} \mathrm{C}_{\mathrm{R}}$ did not demonstrate large variability in the range of observed soil moisture values (Fig. $\underline{1 h}$ ). At the pine forest, in contrast, there was a decline in ${ }^{13} \mathrm{C}_{\mathrm{R}}$ with increasing soil moisture (Fig. $\underline{1 h}$ ).

\section{Soil $\mathrm{CO}_{2}$ flux}

Soil $\mathrm{CO}_{2}$ fluxes showed a seasonal pattern at both locations (Table $\underline{3}$ ). Minima in soil $\mathrm{CO}_{2}$ flux were measured during the winter months, while maxima were measured during the growing season (Table 3 ). With the exception of September 2002 soil $\mathrm{CO}_{2}$ fluxes were higher at the hardwood forest and averaged $4.86 \pm 1.33$ and $3.52 \pm 0.39 \mu_{\text {moles }} \mathrm{CO}_{2} \mathrm{~m}^{-2} \mathrm{~s}^{-1}$ at the hardwood and pine forests, respectively (Table $\underline{3}$ ).

Table 3 Soil Respiration rates ( $\mu$ moles $\mathrm{CO}_{2} \mathrm{~m}^{-2} \mathrm{~s}^{-1}$; mean $\pm 1 / 2$ range of variability of duplicate chambers). Errors were propagated for calculation of the grand mean

\begin{tabular}{|l|l|l|}
\hline Date & Hardwood & Pine \\
\hline 15 Nov 2000 & - & $1.42 \pm 0.16$ \\
\hline 21 Feb 2001 & $1.44 \pm 0.03$ & - \\
\hline 12 Jun 2001 & $6.25 \pm 0.22$ & $4.76 \pm 0.04$ \\
\hline 29 Aug 2001 & $7.82 \pm 0.46$ & $4.02 \pm 0.11$ \\
\hline 27 Nov 2001 & $4.26 \pm 0.41$ & $3.72 \pm 0.23$ \\
\hline 15 Mar 2002 & $2.98 \pm 0.33$ & $2.08 \pm 0.21$ \\
\hline 10 Jul 2002 & $5.95 \pm 0.95$ & $2.39 \pm 0.12$ \\
\hline 5 Sep 2002 & $5.33 \pm 0.58$ & $6.25 \pm 0.00$ \\
\hline
\end{tabular}




\section{Discussion}

This study is the first to compare the temporal variability in the carbon isotopic composition of respired $\mathrm{CO}_{2}$ for two forest types located in close proximity and exposed to the same climatic conditions and with similar soils. To address the study objectives, we first evaluate the causes for differences in long-term carbon isotopic discrimination between pine and hardwood forests, focusing on mean $\delta^{13} \mathrm{C}_{\mathrm{F}}$ and $\delta{ }^{13} \mathrm{C}_{\mathrm{P}}$ because of their linkage to conductance and photosynthesis. We follow with an analysis of the causes of temporal variability in isotopic discrimination at each forest and their linkage to environmental drivers such as VPD and soil moisture. The co-variation amongst the three isotopic discrimination variables is also analyzed.

\section{Leaf-level isotopic differences between pine and hardwood stands}

As stated earlier, ${ }^{13} \mathrm{C}_{\mathrm{F}}$ collected just prior to dawn, increased with increasing VPD for both stands (Fig. 1a). At the leaf level, photosynthetic discrimination is related to $\left[\mathrm{Ci} / \mathrm{Ca}\right.$ ], where $\mathrm{Ci}$ is the canopy-scale intercellular $\mathrm{CO}_{2}$ concentration and $\mathrm{Ca}$ is the ambient $\mathrm{CO}_{2}$ concentration, which is affected by environmental factors (Farquhar et al. 1989), such as VPD, through their effect on photosynthesis or canopy conductance. The highest correlation between $\delta{ }^{13} \mathrm{C}_{\mathrm{F}}$ and VPD occurred for a few days (average of day 3 and day 4) prior to sampling, indicating that pre-dawn ${ }^{13} \mathrm{C}_{\mathrm{F}}$ represents the isotopic composition of assimilated carbon during few days prior to sampling, while ${ }^{13} \mathrm{C}_{\mathrm{P}}$ is the temporally integrated value of the ${ }^{13} \mathrm{C}$ of structural material at the time they were assimilated. Once the structural material of the foliage is assimilated there are minor changes with time in its isotopic composition (Fessenden and Ehleringer 2002; Fig. 1c).

\section{Long-term differences}

The $\delta{ }^{13} \mathrm{C}_{\mathrm{F}}$ and $\delta{ }^{13} \mathrm{C}_{\mathrm{P}}$ values in both stands are likely to be affected by differences in plant hydraulic and physiological characteristics because of the similarity in soil and climate. Given the canopy height differences between the two forests and, in turn, expected differences in stomatal conductance (Ryan and Yoder 1997; Schäfer et al. 2000), the similarity in long-term mean values of $\delta^{13} \mathrm{C}_{\mathrm{F}}$ and $\delta^{13} \mathrm{C}_{\mathrm{P}}$ was surprising. Such similarity can materialize only if hydraulic and physiological compensation exists, and is explored next.

The effect of plant hydraulics on canopy conductance is given by

$G_{\mathrm{s}}=K(T) \times\left(k_{\mathrm{s}} \times \frac{A_{\mathrm{s}}}{A_{1}} \times \frac{1}{h}\right) \times\left(\Delta \Psi_{1-\mathrm{s}}-0.01 h\right) \times\left(\frac{1}{\mathrm{VPD}}\right)$

where $G_{\mathrm{s}}$ is stomatal conductance, $K(T)$ are temperature dependent constants (see Phillips and Oren $\underline{1998), ~} T$ is air temperature, $k_{\mathrm{s}}$ is a tissue-specific hydraulic conductivity averaged from the soil to the stomata cells, $A_{\mathrm{s}} / A_{1}\left(\mathrm{~cm}^{2} \mathrm{~m}^{-2}\right)$ is sapwood to leaf area ratio, $h$ is tree height as a surrogate for the path length for water flow, $\Delta \operatorname{PSgr}_{1-\mathrm{s}}$ is the potential gradient for water in megaPascal between the soil and substomata cells, and $0.01 h$ ( $h$ is in $\mathrm{m}$ ) is a correction for the effect of gravity. Using this equation to calculate $G_{\mathrm{S}}$ assumes a good coupling between the leaves and the air in the canopy volume where VPD is measured. 
Based on Table 1, $T$ and VPD are similar in both stands as are the soil type and soil moisture; hence differences in $G_{\mathrm{S}}$ should reflect the combined effects of sapwood to leaf area ratio, canopy height, minimum leaf water potential, and tissuespecific hydraulic conductivity. The $A_{\mathrm{s}} / A_{1}$ in the pine ranges from $\sim 5.9$ before bud-break to $\sim 4.0$ in September. It ranges from 4.4 (Pataki and Oren 2003) to 5.3 (Oren and Pataki 2001) in similar hardwood stands. Thus, we assume that $A_{\mathrm{s}} / A_{1}$ is similar at these two stands. The canopy heights in the pine and hardwood forests are 17.2 and $35 \mathrm{~m}$, respectively. We assume that the minimum leaf water potential is $-1.5 \mathrm{MPa}$ for the hardwood species and $-2.0 \mathrm{MPa}$ for the pine (Cruiziat et al. 2002), and that the soil is near saturation. We further assume that the ratio of pine to hardwood $k_{\mathrm{s}}$ is 0.53 (Becker et al. 1999). Combining the effect of all these factors produces an expected $G_{\mathrm{S}}$ ratio of pine to hardwood of about 1.7. This $G_{\mathrm{S}}$ ratio falls approximately in the middle of the wide range in canopy transpiration ratios (1.1-2.1) estimated in these pine and hardwood stands (Pataki and Oren 2003).

Having estimated the effect of plant hydraulics, we proceed to assess the physiological effects on gas exchange. Eddy covariance measurements in 2001 suggest that the ecosystem level photosynthesis $\left(A_{\mathrm{c}}\right)$ ratio of pines to hardwoods is about 1.45 (P. Stoy et al., in preparation). Combining this information with the $G_{\mathrm{s}}$ ratio, allows us to estimate the expected ratio of $[\mathrm{Ci} / \mathrm{Ca}]_{\text {pine }}$ to $[\mathrm{Ci} / \mathrm{Ca}]_{\text {hardwood }}$, given by

$\frac{1-\left[C_{\mathrm{i}} / C_{\mathrm{a}}\right]_{\text {hardwood }}}{1-\left[C_{\mathrm{i}} / C_{\mathrm{a}}\right]_{\text {pine }}}=\frac{\left[G_{\mathrm{s}}\right]_{\text {pine }}}{\left[G_{\mathrm{s}}\right]_{\text {hardwood }}} \times \frac{\left[A_{\mathrm{c}}\right]_{\text {hardwood }}}{\left[A_{\mathrm{c}}\right]_{\text {pine }}}=1.7 \times \frac{1}{1.45} \approx 1.17$

To compare this estimate with measured $\delta{ }^{13} \mathrm{C}_{\mathrm{F}}$, we calculated $[\mathrm{Ci} / \mathrm{Ca}]_{\text {pine }}$ and $[\mathrm{Ci} / \mathrm{Ca}]_{\text {hardwood }}$ from the $\delta 13 \mathrm{C}_{\mathrm{F}}(\mathrm{Table} 2)$ and averaged the values to obtain long-term means of 0.74 and 0.70 , respectively. The ratio $[C \mathrm{i} / \mathrm{Ca}]$ was calculated from

$\delta^{13} \mathrm{C}_{\mathrm{F}}=\delta^{13} \mathrm{C}_{\mathrm{A}}-a-(b-a) \times\left[C_{\mathrm{i}} / C_{\mathrm{a}}\right]$

where $\delta{ }^{13} \mathrm{C}_{\mathrm{F}}$, is pre-dawn foliage respired $\delta{ }^{13} \mathrm{CO}_{2}, \delta{ }^{13} \mathrm{C}_{\mathrm{A}}=$ background air $\delta{ }^{13} \mathrm{CO}_{2}$ measured at the tower top in daytime, $a=4.4 \%$ diffusional fractionation, and $b=27 \% 0$ fractionation during carboxylation (Farquhar et al. 1982). Prater et al.

(submitted) tested the hypothesis that pre-dawn determination of $C \mathrm{i} / \mathrm{Ca}$ from ${ }^{13} \mathrm{C}_{\mathrm{F}}$ are representative of daytime integrated $\mathrm{Ci} / \mathrm{Ca}$ in pine species. Prater et al. (submitted) suggested that at pre-dawn as the substrate pool used for respiration was depleted in sucrose and glucose the apparent fractionation (Ghashghaie et al. 2003) effects caused by the non-statistical distribution of ${ }^{13} \mathrm{C}$ in those molecules (Rossmann et al. $\underline{1991}$ ) would be minimized. They used a series of $\delta{ }^{13} \mathrm{C}_{\mathrm{F}}$ and photosynthetic uptake measurements on foliage over a diurnal cycle to calculate the ${ }^{13} \mathrm{C}$ of net assimilated carbon during a diurnal cycle. Their results showed excellent agreement between daytime integrated $\mathrm{Ci} / \mathrm{C}$ a measured with a gas exchange system and $C \mathrm{i} / \mathrm{Ca}$ determined from pre-dawn $\delta{ }^{13} \mathrm{C}_{\mathrm{F}}$ using Eq. $\underline{5}$.

With these $C \mathrm{i} / \mathrm{Ca}$ estimates replaced in the left-hand-side of Eq. $\underline{4}$, a ratio of 1.15 is obtained, close to the 1.17 value predicted from plant hydraulics and eddy-covariance-based photosynthesis. If the calculations are repeated with $C \mathrm{i} / \mathrm{Ca}$ estimated from ${ }^{13} \mathrm{C}_{\mathrm{P}}(0.71$ and 0.73 for the hardwood and pine, respectively), the ratio in Eq. 4 drops from 1.17 to 1.07, perhaps reflecting the differences in photosynthesis and conductance integrated over different seasons for the evergreen pine versus the deciduous hardwood. Although the similarity in $[\mathrm{Ci} / \mathrm{Ca}]_{\text {pine }}$ and $[\mathrm{Ci} / \mathrm{Ca}]_{\text {hardwood }}$ appears surprising, it does not reflect similarities in gas exchange parameters; rather, it reflects compensating changes in hydraulics and photosynthetic properties as predicted by the water-carbon equilibrium hypothesis in Katul et al. (2003). 


\section{Intra-annual differences}

The analysis above focused on the long-term average of $\delta{ }^{13} \mathrm{C}_{\mathrm{F}}$ and $\delta{ }^{13} \mathrm{C}_{\mathrm{P}}$. However, the long-term means may mask shortterm differences in responses to environmental variables such as VPD and soil moisture. In Fig. 1 , the $\delta \mathrm{C}$ of all ecosystem components is presented for both forest types in relation to time-lagged VPD and soil moisture variations. Both $\delta 13 \mathrm{C}_{\mathrm{F}}$ and ${ }^{113} \mathrm{C}_{\mathrm{P}}$ decreased with decreasing VPD with the relationship being more significant for $\delta{ }^{13} C_{F}$, as expected, given its shorter integration time. The relationship of these isotopic discrimination variables with soil moisture was weak to none. The implication of the dependence of $\delta{ }^{13} \mathrm{C}_{\mathrm{F}}$ on VPD, and the similarity in the response in both forest types, is discussed below in terms of the dependence of $C \mathrm{i} / \mathrm{Ca}$ on VPD.

\section{Implications to leaf-level physiological models}

Starting with the definition of water use efficiency (WUE) to be WUE $\approx A / E$, where $A$ is leaf-level photosynthesis and $E$ is water vapor flux, replacing a Fickian diffusion parameterization for these fluxes, and after some simplifications, the WUE reduces to

$$
\mathrm{WUE}=\frac{C_{\mathrm{a}}\left(1-\frac{C_{\mathrm{i}}}{C_{\mathrm{a}}}\right)}{1.6 \times \mathrm{VPD}}
$$

Upon rearranging,

$$
\frac{C_{\mathrm{i}}}{C_{\mathrm{a}}}=1-\frac{\mathrm{WUE}}{C_{\mathrm{a}}} 1.6 \times \mathrm{VPD}
$$

which suggests the following: (1) when the WUE is constant (e.g., as in Cowan and Farquhar 1977),Ci/Ca decays linearly with increasing VPD, (2) when the WUE varies with VPD ${ }^{-1}$, which occurs when $A$ is independent of VPD but $E$ is linearly varying with VPD (e.g., see Katul et al. 2000), $\mathrm{Ci} / \mathrm{Ca} \rightarrow$ constant.

The above theoretical predictions are supported by the $C \mathrm{i} / \mathrm{Ca}$ determined from ${ }^{13} \mathrm{C}_{\mathrm{F}}$ for both stands. Notice in Fig. 2 that: 


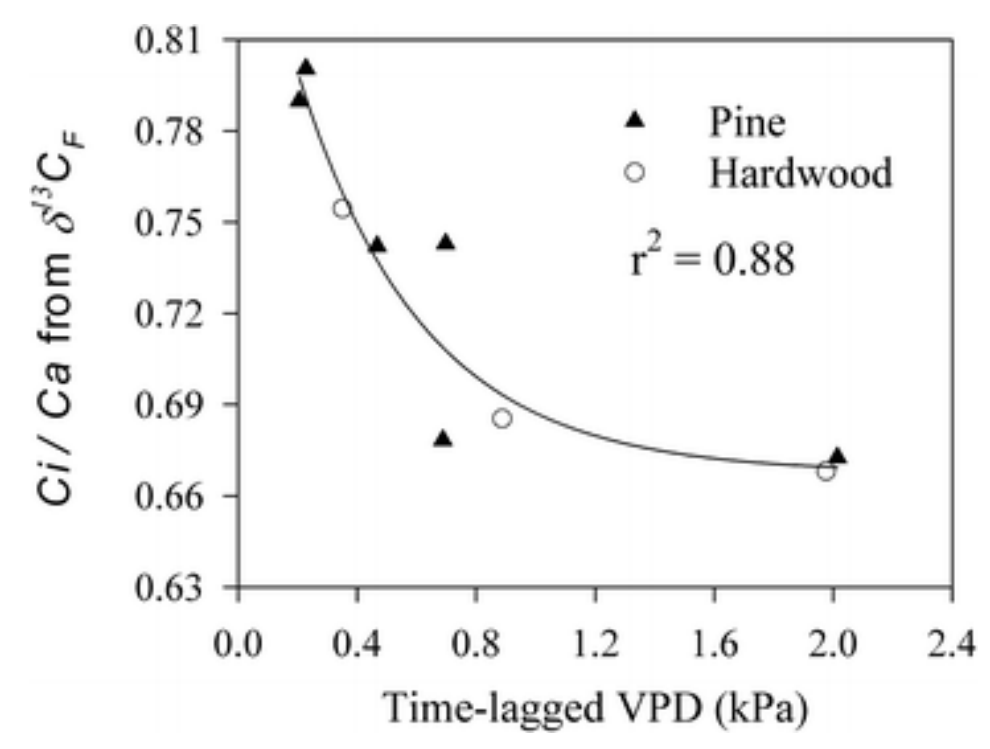

Fig. $2 \mathrm{Ci} / \mathrm{Ca}$ versus time lagged daytime VPD (average of daytime VPD for days 3 and 4 prior to sampling) at the pine and hardwood forest $\left([\mathrm{Ci} / \mathrm{Ca}]=0.6676+0.2122 \times \mathrm{e}^{(-2.3813 \times \mathrm{VPD})}\right)$. Ci/Ca was derived from $\delta{ }^{13} \mathrm{C}_{\mathrm{F}}$ values and the equation in Farquhar et al. (1982) (see text). The long-term mean $\mathrm{Ci} / \mathrm{Ca}$ determined from foliage organic matter ${ }^{13} \mathrm{C}$ is 0.66 (Katul et al. 2000)

For $\mathrm{VPD}<1 \mathrm{kPa}, C \mathrm{i} / \mathrm{Ca}$ decays approximately linearly (and similarly) with VPD for both stands.

For $\mathrm{VPD}>1 \mathrm{kPa}, C \mathrm{i} / \mathrm{Ca}$ is approximately constant, and equal to an earlier stable-isotope based estimate $(=0.66)$ in the pine forest (see Katul et al. 2000, 2003).

To place the observed $\mathrm{Ci} / \mathrm{Ca}$ dependence on VPD in the context of leaf-level photosynthesis models, we consider a simplified Leuning (1995) formulation, now widely used in ecological models, given by

$g=m \frac{A}{C_{\mathrm{a}}} f(\mathrm{VPD})+b^{\prime}$

$A=g\left(C_{\mathrm{a}}-C_{\mathrm{i}}\right)$

$f(\mathrm{VPD})=\frac{1}{1+\frac{\mathrm{VPD}}{D_{\odot}}}$

where $g$ is the leaf-level conductance to $\mathrm{CO}_{2}, m$ and $b^{\prime}$ are species- and condition-specific constants, and $D_{\mathrm{O}}$ is a $V P D$ sensitivity parameter. Neglecting $b^{\prime}$ (when compared to $g$ ) results in 


$$
\frac{C_{\mathrm{i}}}{C_{\mathrm{a}}}=\left(1-\frac{1}{m}\right)-\frac{1}{m D_{\circ}} \mathrm{VPD}
$$

It is not our intent here to use Eqs. $\underline{9}, \underline{10}, \underline{11}$ in a prognostic manner; rather we seek a diagnostic description of the $C \mathrm{i} / \mathrm{Ca}$ dependence on VPD. Clearly, the model described by Eq. 11 is not correct over the entire range of VPD because it predicts a continuous linear decline in $\mathrm{Ci} / \mathrm{Ca}$ with increasing VPD. The data in Fig. 2 shows an asymptotic behavior with increasing VPD. Similar deficiencies emerge with the Cowan and Farquhar (1977) model, which assumes a constant WUE and predicts a continuous linear decline in $C \mathrm{i} / C$ a with increasing VPD. Another model proposes a constant WUE defined as $\lambda_{\mathrm{cf}}=\partial E / \partial A$ (rather than $A / E$ as we did above), and uses a linearized $A-C_{\mathrm{I}}$ curve (Lloyd and Farquhar 1994). With these simplifications, it can be shown that (Katul et al. 2000):

$$
\frac{C_{\mathrm{i}}}{C_{\mathrm{a}}}=1-\sqrt{\frac{1.6 \mathrm{VPD}\left(C_{\mathrm{a}}-\Gamma\right)}{\lambda_{\mathrm{cf}} C_{\mathrm{a}}^{2}}}
$$

where $\Gamma$ is the $\mathrm{CO}_{2}$ compensation point. In short, this model predicts that

$$
\frac{C_{\mathrm{i}}}{C_{\mathrm{a}}}=1-m^{\prime} \sqrt{\mathrm{VPD}}
$$

where $m^{\prime}$ is a constant, that depends on $\Gamma, \lambda_{\text {cf }}$, and $C$ a. While this model exhibits some nonlinear dependence on VPD, the curvature is too mild to represent the observed pattern in $C \mathrm{i} / \mathrm{Ca}$ versus VPD shown in Fig. $\underline{2}$.

To summarize, from stable isotopes, we show that the current empirical physiological models do not represent well the nonlinear dependence of Ci/Ca on VPD across the entire VPD range. Furthermore, the similarity in the $C \mathrm{i} / C \mathrm{a}$ measurements in Fig. 2 suggests that for a given VPD,

$$
\frac{A_{\text {pine }}}{A_{\text {hardwood }}} \approx \frac{E_{\text {pine }}}{E_{\text {hardwood }}}=\frac{g_{\text {pine }}}{g_{\text {hardwood }}}=\frac{g_{\text {ref,pine }} \times f_{\text {pine }}(\theta) \times[1-0.6 \log (\mathrm{VPD})]}{g_{\text {ref , hardwood }} \times f_{\text {hardwood }}(\theta) \times[1-0.6 \log (\mathrm{VPD})]} \approx 1.7 \frac{f_{\text {pine }}(\theta)}{f_{\text {hardwood }}(\theta)}
$$

where $g_{\text {ref }}$ is the reference conductance at $\mathrm{VPD}=1 \mathrm{kPa}$ (Oren et al. 1999), and $f(\theta) \in[0,1]$ is the stomatal conductance sensitivity to soil moisture. In the above formulation, the conductance was modeled after Jarvis (1976) with $g$ sensitivity to VPD set proportional to $g_{\text {ref }}($ Oren et al. 1999). Based on this formulation, the ratio of assimilation rates at these two forests will be constant for a given soil moisture condition regardless of the variation in VPD, but will change depending on the sensitivity of those two stands to soil moisture. Previous studies have shown that the conductance in the pine forest is more sensitive to soil moisture content depletion than the hardwood forest (Oren et al. 1998; Oren and Pataki 2001; Pataki and Oren 2003). 


\section{Influence of aboveground processes on $\delta^{13} \mathrm{C}_{\mathrm{S}}$}

${ }^{13} \mathrm{C}_{\mathrm{S}}$ increased with increasing ${ }^{113} \mathrm{C}_{\mathrm{F}}\left(r^{2}=0.87\right.$, freeze event omitted, nighttime temperatures dropped to below $0.0^{\circ} \mathrm{C}$ 3 days prior to sampling), but soil respired $\mathrm{CO}_{2}$ was at all times ${ }^{13} \mathrm{C}$ enriched relative to foliage respired $\mathrm{CO}_{2}$, with the largest difference between $\delta^{13} \mathrm{C}_{\mathrm{F}}$ and $\delta{ }^{13} \mathrm{C}_{\mathrm{S}}$ measured after the freeze event (Fig. $\underline{3}$ ). The relative contributions of heterotrophic respiration of soil organic matter and autotrophic respiration will both contribute to the composition and the variability in $\delta^{13} \mathrm{C}_{\mathrm{S}} \cdot{ }^{13} \mathrm{C}_{\mathrm{F}}$ results from the respiration of recent photosynthate, which will have a variable ${ }^{13} \mathrm{C}$ composition $\left(-31.0 \% 0<\delta 13 \mathrm{C}_{\mathrm{F}}<-27.2 \%\right.$, Table 1 ) depending on the environmental conditions (Fig. 1a). $\delta{ }^{13} \mathrm{C}_{\mathrm{S}}$ results from respiration of recent photosynthate transported to the root system as well as respiration of a relatively older carbon pool with a relatively constant isotopic composition (Trumbore 2000). Soil organic matter at 0-15 cm depth has an estimated mean residence time of 20 years and a mean ${ }^{13} \mathrm{C}$ value of $-26.24 \%$ (range -25.83 to $-27.14 \%$ for the $<0.53 \mu_{\mathrm{m}}$ and coarse fractions, respectively) (Schlesinger and Lichter $\underline{2001}$ ). While $\delta{ }^{13} \mathrm{C}_{\mathrm{F}}$ will tend to introduce temporal variability in $\delta \mathrm{C}_{\mathrm{S}}$, respiration of the soil organic matter with a relatively long residence time and a constant isotopic composition will tend to maintain $\delta^{13} \mathrm{C}_{\mathrm{S}}$ relatively constant (Fig. 1e, f). This buffering effect was more apparent at the hardwood forest (Fig. 1f). However, the high degree of correlation between $\delta^{13} \mathrm{C}_{\mathrm{S}}$ and $\delta^{13} \mathrm{C}_{\mathrm{F}}$ highlights the influence of aboveground processes on the isotopic composition of soil respired $\mathrm{CO}_{2}$.

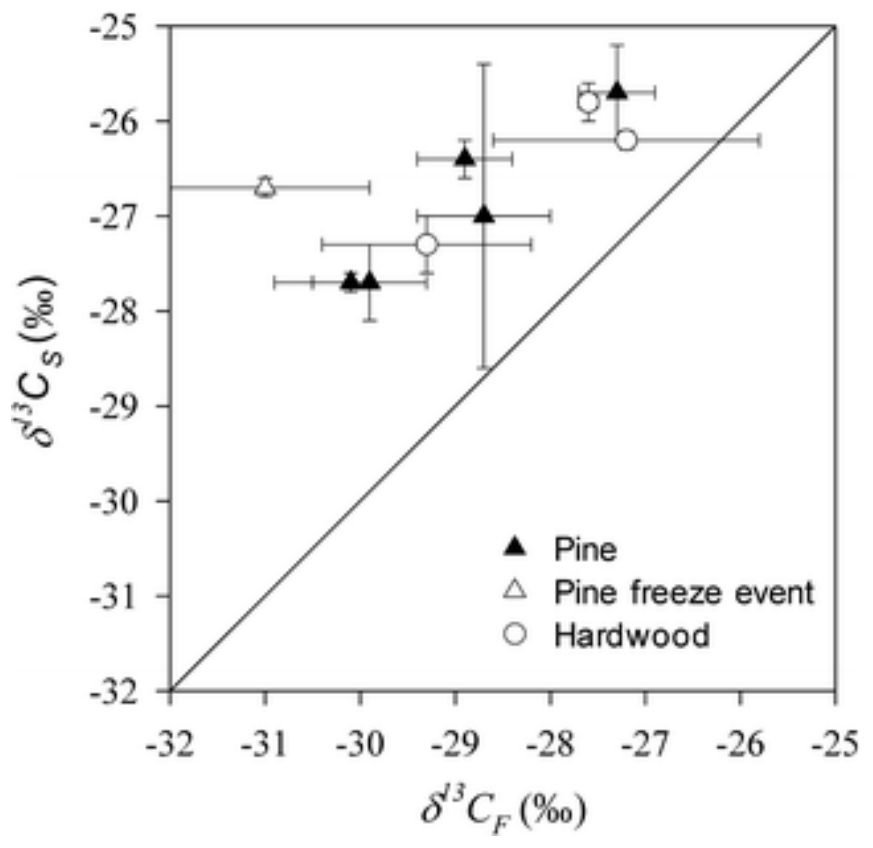

Fig. 3 Scatter plot of $\delta{ }^{13} C_{S}$ versus $\delta{ }^{13} C_{F}\left(r^{2}=0.87\right.$, freeze event omitted). The solid line represents the $1: 1$ relation. Notice that $\delta{ }^{13} C_{S}$ is at all times enriched relative to $\delta{ }^{13} \mathrm{C}_{\mathrm{F}}$, with the largest difference observed after the freeze event at the pine forest. There was a greater range of variability in $\delta{ }^{13} \mathrm{C}_{\mathrm{F}}$ at both forests compared to $\delta{ }^{13} \mathrm{C}_{\mathrm{S}}$. The contribution of heterotrophic respiration of soil organic matter with a relatively constant isotopic composition buffers changes induced in $\delta{ }^{13} \mathrm{C}_{\mathrm{S}}$ by ${ }^{13} \mathrm{C}_{\mathrm{F}}$

Temporal variations in ${ }^{13} \mathrm{C}_{\mathrm{S}}$ have also been reported in a number of studies. For example, Ekbald and Högberg (2001) measured a $5 \% 0$ difference in ${ }^{13} \mathrm{C}_{\mathrm{S}}$ during the June-October period in a boreal mixed coniferous forest. Fessenden and 
Ehleringer (2003) also measured variability in $\delta^{13} \mathrm{C}_{\mathrm{S}}$ of approximately $6 \%$ in an old growth coniferous forest in the northwest Pacific during a annual period. Maxima in $\delta{ }^{13} \mathrm{C}_{\mathrm{S}}$ values were measured during drier periods (Ekbald and Högberg 2001; Fessenden and Ehleringer 2003) suggesting some soil moisture control on the variability of $\delta{ }^{13} \mathrm{C}_{\mathrm{S}}$. The fact the $\delta{ }^{13} \mathrm{C}_{\mathrm{S}}$ at the Duke Forests shows lower temporal variations compared to $\delta{ }^{13} \mathrm{C}_{\mathrm{F}}$ (Table $\underline{2}$, Fig. 1a,e,f) suggests that at the two stands a large fraction of soil-respired $\mathrm{CO}_{2}$ results from respiration of organic matter with a relatively long residence time.

\section{Temporal and spatial variability in $\delta{ }^{13} \mathbf{C}_{\mathbf{R}}$ at the Duke Forest}

${ }^{13} \mathrm{C}_{\mathrm{R}}$ was correlated to time-lagged VPD at the pine and hardwood stands (Fig. $1 \mathrm{~g}$ ). This is in agreement with earlier findings (Bowling et al. 2002; Fessenden and Ehleringer 2003), and suggests that $\delta{ }^{13} C_{R}$ is enriched during high VPD and low soil moisture conditions (Fig. $1 \mathrm{~g}, \mathrm{~h}$ ). The ${ }^{1{ }^{13}} \mathrm{C}_{\mathrm{R}}$ is thought to reflect ecosystem scale photosynthetic discrimination (Buchmann et al. 1998; Flanagan and Ehleringer 1998), and should be influenced by environmental variables such as VPD and soil moisture that affect stomatal conductance (Farquhar et al. 1989). Stomatal responses at diurnal and daily scales are mainly influenced by atmospheric conditions, whereas longer-term responses are likely to be controlled by variations in soil water content and rooting characteristics (Schulze 1986; Pataki 1998). Bowling et al. (2002) have observed a significant relation between ${ }^{13} \mathrm{C}_{\mathrm{R}}$ and time-lagged VPD (between 5 and 9 days) for four Pacific Northwest coniferous forests. The relation between $\delta{ }^{13} C_{R}$ and VPD for the four forests followed the same general pattern. Fessenden and Ehleringer (2002) also measured a difference in $\delta^{13} \mathrm{C}_{\mathrm{R}}$ of $0.7 \% 0$ along a chronosequence of coniferous forest (20-450 years) in the Northwest Pacific and attributed the ${ }^{13} \mathrm{C}$ enriched $\delta{ }^{13} \mathrm{C}_{\mathrm{R}}$ values at the older forest to decreased stomatal conductance in the older trees. Ometto et al. (2002) and Pataki et al. (2003) reported a significant relation between $\delta{ }^{13} \mathrm{C}_{\mathrm{R}}$ and precipitation on seasonal and annual scales, respectively, and attributed this to the influence of soil moisture on stomatal conductance (Pataki et al. 2003).

Interestingly the relation between $\delta{ }^{13} \mathrm{C}_{\mathrm{R}}$ and VPD in our stands that are within a kilometer of each other exhibited distinct patterns (Fig. 1g). While $\delta{ }^{13} \mathrm{C}_{\mathrm{R}}$ at the hardwood was linearly related to time-lagged VPD, $\delta{ }^{13} \mathrm{C}_{\mathrm{R}}$ at the pine forest exhibited a non linear dependence on VPD (Fig. 1 g). Furthermore, at the hardwood forest, in contrast to the pine forest, there was only minor variability in $\delta{ }^{13} \mathrm{C}_{\mathrm{R}}$ in response to changes in VPD and soil moisture conditions (Fig. $\left.1 \mathrm{~g}, \mathrm{~h}\right)$. The distinct patterns in $\delta{ }^{13} \mathrm{C}_{\mathrm{R}}$ in response to water availability at the two stands results from the relative influence of $\delta 13 \mathrm{C}_{\mathrm{S}}$ and ${ }^{13} \mathrm{C}_{\mathrm{F}}$ on $\delta{ }^{13} \mathrm{C}_{\mathrm{R}}$. At the pine forest, $\delta{ }^{13} \mathrm{C}_{\mathrm{S}}$ and soil moisture were correlated, $\left(r^{2}=0.52\right)$ but no relation existed between the two parameters at the hardwood forest. This lower variability in $\delta{ }^{13} \mathrm{C}_{\mathrm{S}}$ compared to ${ }^{13} \mathrm{C}_{\mathrm{F}}$ will buffer changes in $\delta 13 \mathrm{C}_{\mathrm{R}}$ (Mortazavi and Chanton 2002a). This was particularly apparent in changes in $\delta 1{ }^{13} \mathrm{C}_{\mathrm{R}}$ at the hardwood forest from July to September 2002: while $\delta{ }^{13} \mathrm{C}_{\mathrm{F}}$ changed by $2.1 \% 0, \delta{ }^{13} \mathrm{C}_{\mathrm{R}}$ only varied by $1.0 \%$, a change that is similar to that of $\delta 13 \mathrm{C}_{\mathrm{S}}$ (Table 2).

From comparisons of $\delta{ }^{13} \mathrm{C}_{\mathrm{R}}$ with its components (Fig. 4), it is clear that in the pine forest $\delta 13 \mathrm{C}_{\mathrm{R}}$ is controlled primarily by ${ }^{13} \mathrm{C}_{\mathrm{F}}$, while at the hardwood forest the primary contributor to ${ }^{13} \mathrm{C}_{\mathrm{R}}$ is forest floor respiration. Higher soil $\mathrm{CO}_{2}$ fluxes at the hardwood forest (Table $\underline{3}$ ) and $45 \%$ lower assimilation rates (discussed earlier, P. Stoy et al., in preparation) compared to the pine forest, combined with relatively constant $\delta{ }^{13} \mathrm{C}_{\mathrm{S}}$ despite variations in VPD (Fig. 1a) and soil moisture (Fig. $1 \mathrm{~b}$ ), contribute to maintaining a relatively constant $\delta{ }^{13} \mathrm{C}_{\mathrm{R}}$ at the hardwood forest. These isotopic discrimination measurements are consistent with the observations of higher photosynthesis in the pine forest (discussed earlier) and greater forest floor respiration in the hardwood forest (Table $\underline{3}$ ). 
Fig. 4a-c Scatter diagram a $\delta 13 \mathrm{C}_{\mathrm{F}}$ versus $\delta 13 \mathrm{C}_{\mathrm{R}}$, b $\delta{ }^{13} \mathrm{C}_{\mathrm{P}}$ versus $\delta{ }^{13} \mathrm{C}_{\mathrm{R}}$ and $\mathbf{c} \delta{ }^{13} \mathrm{C}_{\mathrm{S}}$ versus $\delta 13 \mathrm{C}_{\mathrm{R}}$. The solid lines represent the $1: 1$ relation. Notice that while at the pine forest ${ }^{1}{ }^{13} \mathrm{C}_{\mathrm{R}}$ is mainly influenced by ${ }^{1}{ }^{13} \mathrm{C}_{\mathrm{F}}$, at the hardwood forest $\delta{ }^{13} \mathrm{C}_{\mathrm{R}}$ is mainly influenced by ${ }^{13} \mathrm{C}_{\mathrm{S}}$. This is consistent with higher assimilation rates at the pine and lower assimilation rates and higher soil $\mathrm{CO}_{2}$ fluxes at the hardwood forest

\section{Conclusions}

This study quantified variations in ${ }^{13} \mathrm{C}_{\mathrm{R}}$ and its components in adjacent pine and the hardwood forests in southeastern USA. We demonstrated a remarkable similarity in the relationship between $C \mathrm{i} / C$ a and VPD in the two forests despite large differences in hydraulic characteristics. This similarity is the outcome of physiological adjustments that compensated for the differences in hydraulic characteristics between the forests as expected based on a recent equilibrium hypothesis (Katul et al. 2003). Results indicate that in a mosaic of forests composed of different stands, different factors contribute to the variations in $\delta^{13} \mathrm{C}_{\mathrm{R}}$ : (1) in deciduous broadleaf stands, the isotopic composition of the forest floor $\mathrm{CO}_{2}$ efflux dominates ${ }^{113} \mathrm{C}_{\mathrm{R}}$ while in a younger pine forest, the isotopic composition of foliage respired $\mathrm{CO}_{2}$ dominates $\delta 13 \mathrm{C}_{\mathrm{R}}$; (2) given the relatively low variability of $\delta^{13} \mathrm{C}_{\mathrm{S}}$, dominated by long residence time soil organic matter, $\delta^{13} \mathrm{C}_{\mathrm{R}}$ in the hardwood forest was nearly constant; (3) given the relatively variable nature of $\delta{ }^{13} \mathrm{C}_{\mathrm{F}}$, dominated by the effect of VPD on stomatal conductance, $\delta{ }^{13} \mathrm{C}_{\mathrm{R}}$ in the pine forest was variable. Because of the sensitivity of the atmospheric inversion models to ${ }^{113} \mathrm{C}_{\mathrm{R}}$, these models merit incorporation of the effect of stand characteristics on $\delta^{13} \mathrm{C}_{\mathrm{R}}$, in addition to previously recognized effects of moisture availability (Bowling et al. 2002; Ometto et al. 2002) and age (Fessenden and Ehleringer 2002).

Acknowledgements We would like to thank Paul Stoy for help with the environmental data. Support was provided by the Biological and Environmental Research (BER) Program, US Department of Energy, through the Southeast Regional Center (SERC) of the National Institute for Global Environmental Change (NIGEC), and through the Terrestrial Carbon Processes Program (TCP, DE-FG02-00ER63016) the FACE project and the National Science Foundation (\# 0343604). This paper benefitted from the constructive comments of two anonymous reviewers.

\section{References}

Bakwin PS, Tans PP, White JWC, Andres RJ (1998) Determination of the isotopic $\left({ }^{13} \mathrm{C} /{ }^{12} \mathrm{C}\right)$ discrimination by terrestrial biology from a global network of observations. Global Biogeochem Cycles 12:555-562

CrossRef ChemPort

Becker P, Tyree MT, Tsuda M (1999) Hydraulic conductances of angiosperms versus conifers: similar transport sufficiency at the whole-plant level. Tree Physiol 19:445-452

Bowling DR, Tans PP, Monson RK (2001) Partitioning net ecosystem carbon exchange with isotopic fluxes of $\mathrm{CO}_{2}$. Global $\mathrm{Change}$ Biol 7:127-145

CrossRef 
Bowling DR, McDowell NG, Bond BJ, Law BE, Ehleringer JR (2002) ${ }^{13} \mathrm{C}$ content of ecosystem respiration is linked to precipitation and vapor pressure deficit. Oecologia 131:113-124

[SpringerLink]

Buchmann N, Kaplan JO (2001) Carbon isotopic discrimination of terrestrial ecosystems-how well do observed and modeled results match? In: Schulze ED et al (eds) Global biogeochemical cycles in the climate system. Academic, San Diego, pp 253-266

Buchmann N, Brooks JR, Flanagan LB, Ehleringer JR (1998) Carbon isotope discrimination of terrestrial ecosystem. In: Griffiths H (ed) Stable isotopes-integration of biological ecological and geochemical processes. Bios Scientific, Oxford, pp 203-221

Ciais P, Tans PP, Trolier M, White JWC, Francey RJ (1995a) A large northern hemisphere terrestrial $\mathrm{CO}_{2}$ sink indicated by the ${ }^{13} \mathrm{C} /{ }^{12} \mathrm{C}$ ratio of atmospheric $\mathrm{CO}_{2}$. Nature $269: 1098-1102$

ChemPort

Ciais P, Tans PP, White JWC, Trolier M, Francey RJ, Berry JA, Randall DR, Sellers PJ, Collatz JG, Schimel DS (1995b) Partitioning of ocean and land uptake of $\mathrm{CO}_{2}$ as inferred by ${ }^{13} \mathrm{C}$ measurements from the NOAA climate monitoring and diagnostics laboratory global air sampling network. J Geophys Res 100:5051-5070

CrossRef ChemPort

Clark KL, Gholz HL, Moncrieff JB, Cropley F, Loescher HW (1999) Environmental controls over net exchanges of carbon dioxide from contrasting Florida ecosystems. Ecol Appl 9:936-948

Conte MH, Weber JC (2002) Plant biomarkers in aerosols record isotopic discrimination of terrestrial photosynthesis. Nature 417:639641

\begin{tabular}{|l|l|l|l|l}
\hline CrossRef & ChemPort PubMed \\
\hline
\end{tabular}

Cowan IR, Farquhar mD (1977) Stomatal function in relation to leaf metabolism and environment, stomatal function in the regulation of plant exchange. In: Jennings JH (ed) vol 31. Cambridge University Press, Cambridge, pp 471-505

Cruiziat P, Cochard H, Ameglio T (2002) Hydraulic architecture of trees: main concepts and results. Ann For Sci 59:723-752 CrossRef

Davidson EA, Trumbore SE (1995) Gas diffusivity and production of $\mathrm{CO}_{2}$ in deep soils of the eastern Amazon. Tellus 47:550-565 CrossRef

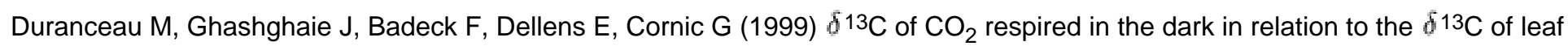
carbohydrates in Phaseolus vulgaris L under progressive drought. Plant Cell Environ 22:515-523

CrossRef

Ehleringer JR, Bowling DR, Flanagan LB, Fessenden J, Helliker B, Martinelli LA, Ometto JP (2002) Stable isotopes and carbon cycle processes in forests and grasslands. Plant Biol 4:181-189

CrossRef

Ekbald A, Högberg P (2001) Natural abundance of ${ }^{13} \mathrm{C}$ in $\mathrm{CO}_{2}$ respired from forest soils reveals speed of link between tree photosynthesis and root respiration. Oecologia 127:305-308

[SpringerLink]

Evans JR, Sharkey TD, Berry JA, Farquhar MD (1986) Carbon isotope discrimination measured concurrently with gas exchange to investigate $\mathrm{CO}_{2}$ diffusion in leaves of higher plants. Aust J Plant Physiol 13:281-292 
Farquhar MD, O' Leary MH, Berry JA (1982) On the relationship between carbon isotope discrimination and the intercellular carbon dioxide concentration in leaves. Aust J Plant Physiol 9:121-137

Farquhar MD, Ehleringer JR, Hubick KT (1989) Carbon isotope discrimination and photosynthesis. Annu Rev Plant Physiol Plant Mol Biol 40:503-537

CrossRef ChemPort

Fessenden JE, Ehleringer JR (2002) Age-related variations in $\delta^{13} \mathrm{C}$ of ecosystem respiration across a coniferous forest chronosequence in the Pacific Northwest. Tree Physiol 22:159-167

Fessenden JE, Ehleringer JR (2003) Temporal variation in $\delta 13 \mathrm{C}$ of ecosystem respiration in the Pacific Northwest: links to moisture stress. Oecologia 136:129-136

[SpringerLink] PubMed

Flanagan LB, Ehleringer JR (1998) Ecosystem-atmosphere $\mathrm{CO}_{2}$ exchange: interpreting signals of change using stable isotope ratios. Trends Ecol Evol 13:10-14

CrossRef

Fung I, Field CB, Berry JA, Thompson MV, Randerson JT, Malmstrom CM, Vitousek PM, Collatz GJ, Sellers PJ, Randall DA, Denning AS, Badeck F, John J (1997) Carbon 13 exchanges between the atmosphere and biosphere. Global Biogeochem Cycles 11:507-533 CrossRef ChemPort

Ghashghaie J, Duranceau M, Badeck F, Cornic G, Adeline MT, Deleens E (2001) $\delta 13 \mathrm{C}$ of $\mathrm{CO}_{2}$ respired in the dark in relation to leaf metabolites: comparisons between Nicotiana sylvestirs and Helianthus annuus under drought. Plant Cell Environ 24:505-515 CrossRef ChemPort

Ghashghaie J, Badeck FW, Langian G, Nogues S, Tcherkez G, Deleens E, Cornic G, Griffiths H (2003) Carbon isotope fractionation during dark respiration and photorespiraiton in $\mathrm{C}_{3}$ plants. Phytochem Rev 2:145-161

CrossRef ChemPort

Gillon JS, Yakir D (2000) Internal conductance to $\mathrm{CO}_{2}$ diffusion and $\mathrm{C}^{18} \mathrm{OO}$ discrimination in $\mathrm{C} 3$ leaves. Plant Physiol 123:201-213 CrossRef ChemPort PubMed

Harwood KG, Gillon JS, Griffiths H, Broadmeadow MSJ (1993) Diurnal variations of $\Delta^{13} \mathrm{CO}_{2}, \Delta \mathrm{C}^{18} \mathrm{O}^{16} \mathrm{O}$ and evaporative site enrichment of $\Delta \mathrm{H}_{2}{ }^{18} \mathrm{O}$ in Piper aduncum under field conditions in Trinidad. Plant Cell Environ 21:269-283

CrossRef

Hoerling M, Kumar A (2003) The perfect ocean for drought. Science 299:691-694

CrossRef ChemPort PubMed

Hollinger DY, Kelliher FM, Byers JN, Hunt JE, McSeveny TM, Weir PL (1994) Carbon dioxide exchange between an undisturbed oldgrowth temperate forest and the atmosphere. Ecology 75:134-150

Houghton RA, Davidson EA, Woodwell GM (1998) Missing sinks, feedbacks, and understanding the role of terrestrial ecosystems in the global carbon balance. Global Biogeochem Cycles 12:25-34

CrossRef ChemPort

Jarvis PG (1976) The interpretation of the variations in leaf water potential and stomatal conductance found in canopies in the field.

Phil Trans R Soc London 273:593-610

ChemPort 
Katul G, Hsieh CI, Kuhn G, Ellsworth D, Nie DL (1997) Turbulent eddy motion at the forest-atmosphere interface. J Geophys Res 102:13409-13421

CrossRef

Katul GG, Ellsworth DS, Lai CT (2000) Modelling assimilation and intercellular $\mathrm{CO}_{2}$ from measured conductance: a synthesis of approaches. Plant Cell Environ 23:1313-1328

CrossRef

Katul G, Leuning R, Oren R (2003) Relationship between plant hydraulic and biochemical properties derived from a steady-state coupled water and carbon transport model. Plant Cell Environ 26:339-350

ChemPort

Keeling CD (1958) The concentration and isotopic abundances of atmospheric carbon dioxide in rural areas. Geochim Cosmochim Acta 13:322-334

CrossRef ChemPort

Lai C, Katul G, Butnor J, Ellsworth D, Oren R (2002) Modeling nighttime ecosystem respiration by a constrained source optimization method. Global Change Biol 8:1-18

CrossRef

Leuning R (1995) A critical appraisal of a combined stomatal-photosynthesis model for $\mathrm{C}_{3}$ plants. Plant Cell Environ 18:339-355

ChemPort

Lloyd J, Farquhar MD (1994) ${ }^{13} \mathrm{C}$ discrimination during $\mathrm{CO}_{2}$ assimilation by the terrestrial biosphere. Oecologia 99:201-215

Lloyd J, Kruijt B, Hollinger DY, Grace J, Francey RJ, Wong SC, Kelliher FM, Miranda AC, Farquhar MD, Gash JHC, Vygodskaya NN, Wright IR, Miranda HS, Schulze ED (1996) Vegetation effects on the isotopic composition of atmospheric $\mathrm{CO}_{2}$ at local and regional scales: theoretical aspects and a comparison between rain forest in Amazonia and a boreal forest in Siberia. Aust J Plant Physiol 23:371-399

Mikan CJ, Zak DR, Kubiske ME, Pregitzer KS (2000) Combined effects of atmospheric $\mathrm{CO}_{2}$ and $\mathrm{N}$ availability on the below-ground carbon and nitrogen dynamics of aspen mesocosms. Oecologia 124:432-445

Mortazavi B, Chanton JP (2002a) Carbon isotopic discrimination and control of nighttime canopy $\delta 18 \mathrm{O}-\mathrm{CO}_{2}$ in a pine forest in the Southeastern US. Global Biogeochem Cycles 16: DOI 10.1029/2000GB001390

CrossRef

Mortazavi B, Chanton JP (2002b) A rapid and precise technique for measuring $\delta 13 \mathrm{C}-\mathrm{CO}_{2}$ and $\delta 18 \mathrm{O}-\mathrm{CO}_{2}$ ratios at ambient $\mathrm{CO}_{2}$ concentrations for biological applications and the influence of container type and storage time on the sample isotope ratios. Rapid Commun Mass Spectrom 16:1398-1403

\begin{tabular}{|l|l|l|l}
\hline CrossRef & ChemPort PubMed \\
\hline
\end{tabular}

Ometto J, Flanagan LB, Martinelli LA, Moreira MZ, Higuchi N, Ehleringer JR (2002) Carbon isotope discrimination in forest and pasture ecosystems of the Amazon Basin, Brazil. Global Biogeochem Cycles 16:1109

CrossRef

Oren R, Pataki DE (2001) Transpiration in response to variation in microclimate and soil moisture in southeastern deciduous forests. Oecologia 127:549-559

[SpringerLink]

Oren R, Ewers BE, Todd P, Phillips N, Katul G (1998) Water balance delineates the soil layer in which moisture affects canopy conductance. Ecol Appl 8:990-1002 
Oren R, Sperry JS, Katul GG, Pataki DE, Ewers BE, Phillips N, Shäffer KVR (1999) Survey and synthesis of intra- and interspecific variation in stomatal sensitivity to vapour pressure deficit. Plant Cell Environ 22:1515-1526

CrossRef

Pataki DE (1998) Canopy conductance of Pinus taeda, Liquidambar styraciflua and Quercus phellos under varying atmospheric and soil water conditions. Tree Physiol 18:307-315

Pataki DE, Oren R (2003) Species differences in stomatal control of water loss at the canopy scale in a mature bottomland deciduous forest. Adv Water Resour 26:1267-1278

CrossRef

Pataki DE, Ehleringer JR, Flanagan LB, Yakir D, Bowling DR, Still CJ, Buchmann N, Kaplan JO, Berry JA (2003) The application and interpretation of Keeling plots in terrestrial carbon cycle research. Global Biogeochem Cycles 17: DOI 10.1029/2001GB001850

Phillips N, Oren R (1998) A comparison of daily representations of canopy conductance based on two conditional time-averaging methods and the dependence of daily conductance on environmental factors. Ann Sci For 55:217-235

Prater JL, Mortazavi B, Chanton JP (2004) Diurnalvariation of the ${ }^{13} \mathrm{C}$ of foliage-respired $\mathrm{CO}_{2}$ and discrimination against ${ }^{13} \mathrm{Cduring}$ photosynthesis. Plant Cell Environ (submitted)

Randerson JT, Collatz GJ, Fessenden JE, Munoz AD, Still CJ, Berry JA, Fung IY, Suits N, Denning AS (2002) A possible global covariance between terrestrial gross primary production and C-13 discrimination: consequences for the atmospheric C-13 budget and its response to ENSO. Global Biogeochem Cycles 16:1136. DOI 1110.1029/2001GB001845

Rossmann A, Butzenlechner M, Schmidt HL (1991) Evidence for a non-statistical carbon isotope distribution in natural glucose. Plant Physiol 96:609-614

ChemPort

Ryan MG, Yoder BJ (1997) Hydraulic limits to tree height and growth. BioScience 47:235-242

Schäfer KVR, Oren R, Tenhunen JD (2000) The effect of tree height on crown level stomatal conductance. Plant Cell Environ 23:365375

CrossRef

Schimel DS (1995) Terrestrial ecosystem and the carbon cycle. Global Change Biol 1:77-91

Schlesinger WH, Lichter J (2001) Limited carbon storage in soil and litter of experimental forest plots under increased atmospheric $\mathrm{CO}_{2}$. Nature 411:466-469

CrossRef ChemPort PubMed

Schulze ED (1986) Carbon-dioxide and water-vapor exchange in response to drought in the atmosphere and in the soil. Annu Rev Plant Physiol Plant Mol Biol 37:247-274

CrossRef

Tans PP, White JWC (1998) In balance, with a little help from the plants. Science 281:183-194

CrossRef ChemPort

Tans PP, Berry JA, Keeling RF (1993) Oceanic ${ }^{13} \mathrm{C} /{ }^{12} \mathrm{C}$ observations: a new window on ocean $\mathrm{CO}_{2}$ uptake. Global Biogeochem Cycles 7:353-368

ChemPort 
Tcherkez G, Nogues S, Bleton J, Cornic G, Badeck F, Ghashghaie J (2003) Metabolic origin of carbon isotope composition of leaf dark-respired CO2 in Phaseolus vulgaris L. Plant Physiol 131:237-244

\begin{tabular}{|l|l|l|l|l}
\hline CrossRef & ChemPort PubMed \\
\hline
\end{tabular}

Trumbore S (2000) Age of soil organic matter and soil respiration: radiocarbon constraints on belowground C dynamics. Ecol Appl 10:399-411

Valentini R, Matteucci G, Dolman AJ, Schulze ED, Rebmann C, Moors EJ, Granier A, Gross P, Jensen NO, Pilegaard K, Lindroth A, Grelle A, Bernhofer C, Grunwald T, Aubinet M, Ceulemans R, Kowalski AS, Vesala T, Rannik U, Berbigier P, Loustau D, Guomundsson J, Thorgeirsson H, Ibrom A, Morgenstern K, Clement R, Moncrieff J, Montagnani L, Minerbi S, Jarvis PG (2000) Respiration as the main determinant of carbon balance in European forests. Nature 404:861-865 CrossRef ChemPort PubMed

Wofsy SC, Goulden ML, Munger JW, Fan SM, Bakwin PS, Daube BC, Bassow SL, Bazzaz FA (1993) Net exchange of $\mathrm{CO}_{2}$ in a midlatitude forest. Science 260:1314-1317

Yakir D, Sternberg LD (2000) The use of stable isotopes to study ecosystem gas exchange. Oecologia 123:297-311 [SpringerLink] 


\title{
A field-based method for simultaneous measurements of the $\delta^{18} \mathrm{O}$ and $\delta^{13} \mathrm{C}$ of soil $\mathrm{CO}_{2}$ efflux
}

\author{
B. Mortazavi, J. L. Prater, and J. P. Chanton \\ Florida State University, Department of Oceanography, Tallahassee, FL 32306-4320, USA
}

Received: 11 March 2004 - Published in Biogeosciences Discussions: 11 May 2004

Revised: 4 August 2004 - Accepted: 5 August 2004 - Published: 13 August 2004

\begin{abstract}
Three approaches for determining the stable isotopic composition $\left(\delta^{13} \mathrm{C}\right.$ and $\left.\delta^{18} \mathrm{O}\right)$ of soil $\mathrm{CO}_{2}$ efflux were compared. A new technique employed mini-towers, constructed of open-topped piping, that were placed on the soil surface to collect soil-emitted $\mathrm{CO}_{2}$. Samples were collected along a vertical gradient and analyzed for $\mathrm{CO}_{2}$ concentration and isotopic composition. These data were then used to produce Keeling plots to determine the $\delta^{18} \mathrm{O}$ and $\delta^{13} \mathrm{C}$ of $\mathrm{CO}_{2}$ emitted from the soil. These results were then compared to the $\delta^{18} \mathrm{O}$ and $\delta^{13} \mathrm{C}$ of soil-respired $\mathrm{CO}_{2}$ measured with two other techniques: (1) flux chambers and (2) estimation from the application of the diffusional fractionation factor to measured values of below ground soil $\mathrm{CO}_{2}$ and to $\mathrm{CO}_{2}$ in equilibrium with soil water $\delta^{18} \mathrm{O}$. Mini-tower $\delta^{18} \mathrm{O}$ Keeling plots were linear and highly significant $\left(0.81<\mathrm{r}^{2}<0.96\right)$, in contrast to chamber $\delta^{18} \mathrm{O}$ Keeling plots, which showed significant curvature, necessitating the use of a mass balance to calculate the $\delta^{18} \mathrm{O}$ of respired $\mathrm{CO}_{2}$. In the chambers, the values determined for the $\delta^{18} \mathrm{O}$ of soil respired $\mathrm{CO}_{2}$ approached the value of $\mathrm{CO}_{2}$ in equilibrium with surficial soil water, and the results were significantly $\delta^{18} \mathrm{O}$ enriched relative to the minitower results and the $\delta^{18} \mathrm{O}$ of soil $\mathrm{CO}_{2}$ efflux determined from soil $\mathrm{CO}_{2}$. There were close agreements between the three methods for the determination of the $\delta^{13} \mathrm{C}$ of soil efflux $\mathrm{CO}_{2}$. Results suggest that the mini-towers can be effectively used in the field for determining the $\delta^{18} \mathrm{O}$ and the $\delta^{13} \mathrm{C}$ of soil-respired $\mathrm{CO}_{2}$.
\end{abstract}

\section{Introduction}

Stable isotopes of $\mathrm{CO}_{2}\left({ }^{18} \mathrm{O}\right.$ and $\left.{ }^{13} \mathrm{C}\right)$ provide information on carbon exchange between the biosphere and the atmosphere (Francey et al., 1995; Keeling et al., 1995), and insight into

Correspondence to: B. Mortazavi

(mortazavi@ocean.fsu.edu) the role of photosynthesis and respiration in the global carbon cycle (Yakir and Sternberg, 2000). Global carbon budgets using the ${ }^{18} \mathrm{O}$ of atmospheric $\mathrm{CO}_{2}$ and $\mathrm{CO}_{2}$ concentrations (Ciais et al., 1997; Ciais and Meijer, 1998; Peylin et al., 1999) have indicated that soil and plant isotopic fluxes each contribute roughly five times more to the observed temporal variability in the atmospheric $\delta^{18} \mathrm{O}-\mathrm{CO}_{2}$ than do oceanic or fossil fuel burning components (Miller et al., 1999). Because the global and regional scale carbon budgets include a flux of $\mathrm{CO}_{2}$ from the soil to the atmosphere, the determination of the isotopic composition of soil $\mathrm{CO}_{2}$ efflux remains a critical parameter to be measured in these budgets (Ciais and Meijer, 1998; Stern et al., 1999). At ecosystem and regional scales, accurate determination of the isotopic composition of soil respired $\mathrm{CO}_{2}$ is necessary for partitioning ecosystem gas exchange into its components (Yakir and Wang, 1996; Bowling et al., 2003b).

Different approaches have been used to determine the isotopic composition of soil $\mathrm{CO}_{2}$ efflux. In the laboratory setting, dynamic flow-through chambers have been used to estimate the ${ }^{18} \mathrm{O}$ of soil $\mathrm{CO}_{2}$ efflux (Miller et al., 1999). In the field, chambers have been used to measure the ${ }^{18} \mathrm{O}$ (Högberg and Ekblad, 1996; Flanagan et al., 1999; Lin et al., 1999) and the ${ }^{13} \mathrm{C}$ of soil respired $\mathrm{CO}_{2}$ (Flanagan et al., 1999; Ekblad and Hogberg, 2000; Ekblad et al., 2002; Mortazavi and Chanton, 2002a; Fessenden and Ehleringer, 2003). However, with application of chambers, the $\mathrm{CO}_{2}$ concentration gradient from the soil to the atmosphere is disturbed and the ${ }^{18} \mathrm{O}$ of chamber headspace can remain constant despite addition of excess $\mathrm{CO}_{2}$ by soil respiration (Mortazavi and Chanton, 2002a). Alternatively, Mortazavi and Chanton (2002a) assumed that all $\mathrm{CO}_{2}$ at ground level originated from soil respiration and used a mass balance approach between daytime and nighttime $\mathrm{CO}_{2}$ near the soil surface to determine the ${ }^{18} \mathrm{O}$ of $\mathrm{CO}_{2}$ added by soil respiration.

Information about soil ${ }^{18} \mathrm{O}-\mathrm{CO}_{2}$ has also been used to estimate the ${ }^{18} \mathrm{O}$ of soil $\mathrm{CO}_{2}$ efflux (Mortazavi and Chanton, 


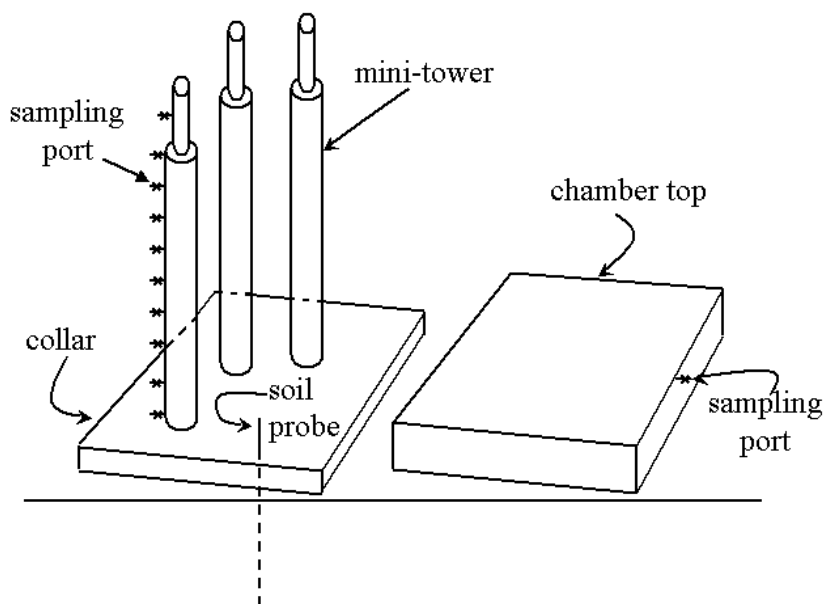

Fig. 1. Schematic of the different approaches used to measure $\mathrm{CO}_{2}$ efflux. The chamber collar $(65 \mathrm{~cm}$ by $65 \mathrm{~cm})$ is inserted into the soil surface. Mini-towers $($ length $=202 \mathrm{~cm}$, base diameter $=7.68 \mathrm{~cm}$ ) are placed within the confines of the collar, and after $2 \mathrm{~min}$, soil $\mathrm{CO}_{2}$ is collected at multiple heights along the towers. The minitowers are removed and then the chamber is sealed and headspace is collected over a $21 \mathrm{~min}$ time interval. Finally, a soil probe is inserted to predetermined depths for collecting soil $\mathrm{CO}_{2}$.

2002a; Bowling et al., 2003b). Soil $\mathrm{CO}_{2}$ undergoes some degree of oxygen isotope exchange with soil water during the following reversible reaction:

$\mathrm{CO}_{2}(\mathrm{aq})+\mathrm{H}_{2} \mathrm{O} \leftrightarrow \mathrm{H}_{2} \mathrm{CO}_{3}(\mathrm{aq})$.

In this hydration reaction and subsequent dissociation, each $\mathrm{CO}_{2}$ molecule exchanges one oxygen atom with liquid water, and in this process the oxygen isotope ratio of $\mathrm{CO}_{2}$ approaches that of soil water (Mills and Urey, 1940). The isotope exchange reaction is described by the following reaction:

$\mathrm{C}^{16} \mathrm{O}_{2}+\mathrm{H}_{2}^{18} \mathrm{O} \leftrightarrow \mathrm{C}^{18} \mathrm{O}^{16} \mathrm{O}+\mathrm{H}_{2}^{16} \mathrm{O}$.

The laboratory data of Miller et al. (1999) suggested that the region between $5-15 \mathrm{~cm}$ below the soil surface has the greatest influence on the $\delta^{18} \mathrm{O}$ of soil-respired $\mathrm{CO}_{2}$. Below $15 \mathrm{~cm}$ the oxygen isotopic composition of $\mathrm{CO}_{2}$ is reset by equilibrium with $\mathrm{H}_{2} \mathrm{O}$. Above $5 \mathrm{~cm} \mathrm{CO}_{2}$ transfer from the soil to the atmosphere is too rapid for $\mathrm{CO}_{2}$ to be influenced by surface soil $\mathrm{H}_{2} \mathrm{O}$. A diffusional fractionation factor is, therefore, applied to soil $\mathrm{CO}_{2}$ at the $5-15 \mathrm{~cm}$ region for determination of the ${ }^{18} \mathrm{O}$ of soil $\mathrm{CO}_{2}$ efflux (e.g. Mortazavi and Chanton, 2002a). In the field, because of the lack of specific knowledge of the depth at which $\mathrm{CO}_{2}$ is in equilibrium with soil $\mathrm{CO}_{2}$ and the effective diffusional fractionation, the ${ }^{18} \mathrm{O}$ of soil $\mathrm{CO}_{2}$ efflux has been estimated by applying the maximum diffusional fraction factor to the ${ }^{18} \mathrm{O}$ of soil $\mathrm{CO}_{2}$ that would be in equilibrium with integrated soil water between the surface and $10 \mathrm{~cm}$ depth (Bowling et al., 2003b).
The correct estimate of the ${ }^{18} \mathrm{O}$ of soil $\mathrm{CO}_{2}$ efflux, however, will depend on (i) the extent to which $\mathrm{CO}_{2}$ diffusing out of a particular layer reaches equilibrium or will be in disequilibrium with water in that layer (Tans, 1998), and (ii) the magnitude of the ${ }^{18} \mathrm{O}$ fractionation factor. It is not clear if the $8.8 \%$ molecular diffusion fractionation factor is always fully expressed as $\mathrm{CO}_{2}$ diffuses from the soil to the atmosphere (Miller et al., 1999). Laboratory investigations (Miller et al., 1999) and modeling efforts (Stern et al., 2001) suggest that the effective diffusional fractionation factor will vary depending on the environmental conditions. Error in the estimation of the oxygen isotopic ratio of soil respired $\mathrm{CO}_{2}$ will impact the results of studies that use the stable isotopes of $\mathrm{CO}_{2}$ to partition ecosystem gas exchange into its components (Yakir and Wang, 1996; Bowling et al., 2003b).

The ${ }^{13} \mathrm{C}$ of soil respired $\mathrm{CO}_{2}$ has also been estimated from soil $\mathrm{CO}_{2}$ concentrations and ${ }^{13} \mathrm{C}$ ratios. A fractionation factor of 4.4\%o (Cerling et al., 1991) is applied to the soil $\mathrm{CO}_{2}$ Keeling intercept to account for the lighter $\mathrm{CO}_{2}$ molecules escaping faster. However, discrepancies can exist between soil $\mathrm{CO}_{2}$ and chamber-based estimates (Mortazavi and Chanton, 2002a). This discrepancy could result because chamberbased estimates integrate the litter layer respiration whereas the soil $\mathrm{CO}_{2}$ estimates ignore the contribution of surface respired material to the isotopic composition of $\mathrm{CO}_{2}$ efflux.

Our objectives were to use an alternative method to static chambers and soil $\mathrm{CO}_{2}$ to simultaneously determine the ${ }^{18} \mathrm{O}$ and ${ }^{13} \mathrm{C}$ of soil respired $\mathrm{CO}_{2}$ in the field. We used open-top piping (mini-towers) placed on the soil surface and collected gas samples along the height of the mini-tower as $\mathrm{CO}_{2}$ diffused from the soil. A Keeling plot of the $\mathrm{CO}_{2}$ concentrations and isotopic ratios of samples collected from multiple heights was used to estimate the isotopic composition of soil respired $\mathrm{CO}_{2}$. Results indicate that the mini-tower approach can be used successfully to simultaneously determine the ${ }^{18} \mathrm{O}$ and ${ }^{13} \mathrm{C}$ of soil $\mathrm{CO}_{2}$ efflux.

\section{Methods}

The investigation was conducted at the Apalachicola National forest $\left(30^{\circ} 20^{\prime} 0.433^{\prime \prime} \mathrm{N}\right.$ and $\left.84^{\circ} 19^{\prime} 0.173^{\prime \prime} \mathrm{W}\right)$ near Tallahassee, FL. The site is dominated by second growth slash pine (Pinus elliottii). The site was visited on 2 June 2003 and 23 June 2003. Two locations (within $50 \mathrm{~m}$ of each other) were sampled during each visit. Upon the second visit, samples were collected within $2 \mathrm{~m}$ of the locations previously sampled.

\subsection{Mini-tower}

Towers were constructed from polyvinyl chloride (PVC) piping. The piping consists of a $7.68 \mathrm{~cm}$ inner diameter PVC $150 \mathrm{~cm}$ long connected via a reducer to a $3.84 \mathrm{~cm}$ PVC pipe $48 \mathrm{~cm}$ long (Fig. 1). The total length of the mini-tower is 
$202 \mathrm{~cm}$. The top of the mini-tower is left open to the atmosphere. Sampling ports equipped with valves were installed at $5,10,20,40,60,80,100,120,140$, and $179 \mathrm{~cm}$ from the ground level. The tower's base was beveled and could be gently inserted $0.5 \mathrm{~cm}$ into the soil surface. Prior to installing the mini-towers they were thoroughly flushed with background air and all the valves were closed. After a $2 \mathrm{~min}$ period following the installation of the mini-towers, samples were sequentially collected during a $15 \mathrm{~min}$ period from the base towards the top. Samples were withdrawn with a syringe and stored in pre-evacuated glass vials $(30 \mathrm{ml})$ capped with Belco ${ }^{\circledR}$ stoppers (Mortazavi and Chanton, 2002b). An in-line magnesium perchlorate trap was used when withdrawing samples to remove moisture. A Keeling plot was used to estimate the ${ }^{18} \mathrm{O}$ and ${ }^{13} \mathrm{C}$ of soil $\mathrm{CO}_{2}$ efflux. During the 23 June 2003 sampling, after placing the tower on the soil surface an initial sample was taken at $179 \mathrm{~cm}$, and then we proceeded as previously described. This allowed a wider range in $\mathrm{CO}_{2}$ concentration, which functioned to reduce the standard error of the intercept of the Keeling plots (Pataki et al., 2003).

\subsection{Chamber measurements}

The chambers have the dimensions of $65 \mathrm{~cm}$ by $65 \mathrm{~cm}$ and are constructed from aluminum. The chambers consist of a collar onto which the top portion can be sealed (Fig. 1). The total enclosed volume is 1001 . The collar is initially inserted into the ground and the chamber top, equipped with a fan to recirculate the headspace, is lowered and sealed. Replicate gas samples $(125 \mathrm{ml})$ from the chamber headspace were drawn with a syringe and stored in pre-evacuated glass vials with Belco ${ }^{\circledR}$ stoppers for later analysis (Mortazavi and Chanton, 2002b). Replicate samples were collected at time 0 and every 7 min during a $21 \mathrm{~min}$ period for $\mathrm{CO}_{2}$ concentration determination and isotopic analysis. A port was left open at the opposite side from the sampling port during sample withdrawal to minimize pressure fluctuations inside the chambers. An in-line magnesium perchlorate trap was used to remove water vapor during the sample collection. $\mathrm{CO}_{2}$ concentration increase with time in the chamber headspace was used to determine soil respiration rates.

\subsection{Soil $\mathrm{CO}_{2}$ profile}

We collected duplicate soil gas samples for $\mathrm{CO}_{2}$ concentration and isotopic analysis with a stainless steel probe $(0.32 \mathrm{~cm}$ outer diameter) inserted at discrete depths $(10,25$, 45 and $84 \mathrm{~cm}$ below the surface). At each depth, duplicate samples were collected. Samples were gently drawn with a syringe and stored in pre-evacuated glass vials $(25 \mathrm{ml})$ capped with Belco ${ }^{\circledR}$ stoppers for later analysis. An in-line magnesium percholorate trap was used to remove moisture from the samples during sample withdrawal.
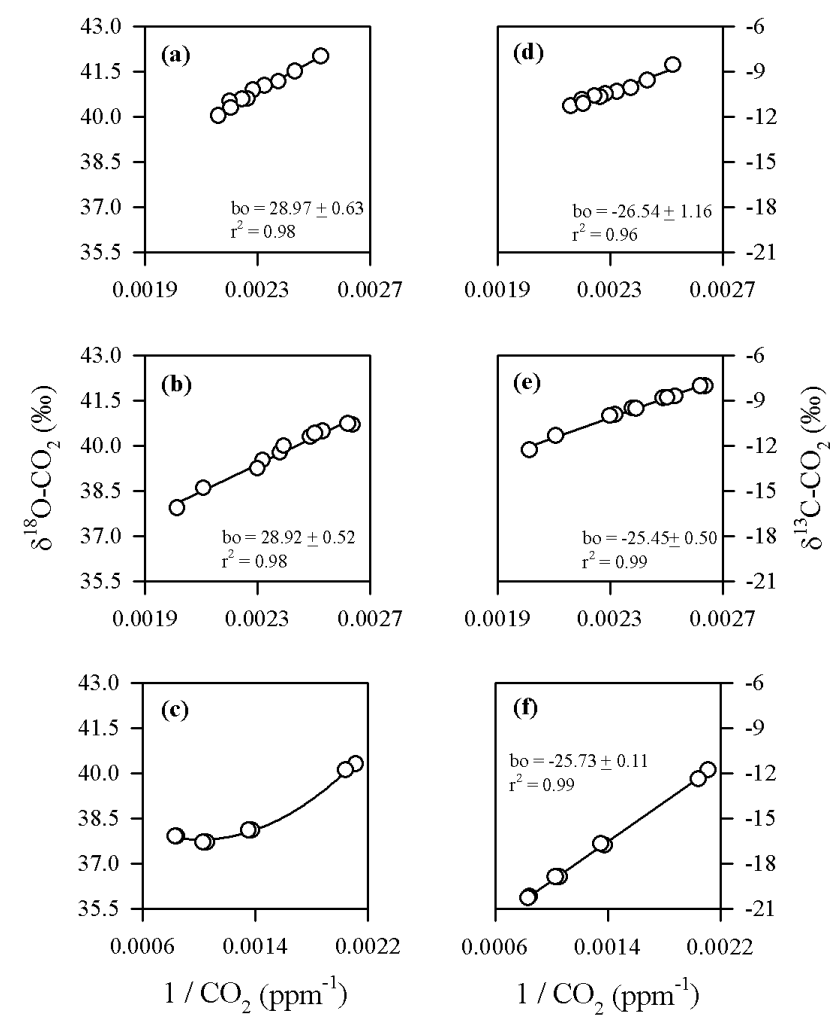

Fig. 2. Examples of $\delta^{18} \mathrm{O}$ and $\delta^{13} \mathrm{C}$ Keeling plots for mini-towers and chambers. (a) $\delta^{18} \mathrm{O}$ Keeling plot for mini-tower \#3, site 1, on 2 June 2003. (b) $\delta^{18} \mathrm{O}$ Keeling plot for mini-tower \#2, site 1 , on 23 June 2003. (c) $\delta^{18} \mathrm{O}$ of $\mathrm{CO}_{2}$ versus its respective $1 / \mathrm{CO}_{2}$ concentration for chamber 1 , site 1 , on 2 June 2003. The fitted line is a second order polynomial. (d) $\delta^{13} \mathrm{C}$ Keeling plot for mini-tower \#3, site 1 , on 2 June 2003. (e) $\delta^{13} \mathrm{C}$ Keeling plot for mini-tower \#2, site 1 , on 23 June 2003. (f) $\delta^{13} \mathrm{C}$ Keeling plot for chamber 1 , site 1 , on 2 June 2003.

\subsection{Sequence of sampling}

Upon arrival at each location, the chamber collar was gently pushed into the sandy soils. The collar is left for $30 \mathrm{~min}$ to minimize any disturbance caused by inserting the collar. Mini-towers $(n=3)$ were placed at different locations within the area encompassed by the chamber collar and height profiles were collected. Next, the chamber was sealed to the collar and the chamber measurements commenced. The same procedure was applied at the second site. The soil probe was inserted to the predetermined depths to collect soil $\mathrm{CO}_{2}$ after a $45 \mathrm{~min}$ period following the chamber measurements (Fig. 1).

At each site, soil samples were collected at the surface $(0-$ $2 \mathrm{~cm}$ ) and at a depth of $10-12 \mathrm{~cm}$ for soil water extraction for ${ }^{18} \mathrm{O}-\mathrm{H}_{2} \mathrm{O}$ analyses. Samples were stored in glass vials and capped and kept frozen until extraction. Surface soil and soil samples at 10, 25, 45 and $84 \mathrm{~cm}$ below the surface were collected for soil organic matter ${ }^{13} \mathrm{C}$ determination and kept frozen until processed in the laboratory. 
Table 1. $\delta^{18} \mathrm{O}(\%)$ of soil $\mathrm{CO}_{2}$ efflux in Apalachicola National Forest. For the chambers a mass balance was used to calculate the ${ }^{18} \mathrm{O}$ of soil $\mathrm{CO}_{2}$ efflux between ${ }^{1} 0$ and $7 \mathrm{~min}$, between ${ }^{2} 7$ and $14 \mathrm{~min}$, and between ${ }^{3} 14$ and $21 \mathrm{~min} .{ }^{4} \mathrm{An} 8.8 \%$ fractionation factor was applied to soil $\mathrm{CO}_{2}$ at $10 \mathrm{~cm}$ to calculate the ${ }^{18} \mathrm{O}$ of soil $\mathrm{CO}_{2}$ efflux. The error corresponds to half the range of variability of duplicate soil ${ }^{18} \mathrm{O}-\mathrm{CO}_{2}$ samples. ${ }^{5} \mathrm{An} 8.8 \%$ fractionation factor was applied to the ${ }^{18} \mathrm{O}$ of $\mathrm{CO}_{2}$ assumed in equilibrium with soil water extracted from soil samples collected at $10-12 \mathrm{~cm}$ depth (mean \pm standard deviation of triplicate samples) to calculate the ${ }^{18} \mathrm{O}$ of soil $\mathrm{CO}_{2}$ efflux. The numbers in the parentheses indicate the sample numbers used in the regression and the $\mathrm{r}^{2}$, respectively). The values for the mini-towers represnt the intercept of the Keeling plot and the SE. For mean mini-towers the error has been propagated. With the exception of site 2 on 2 June $2003, \delta^{18} \mathrm{O}$ of soil $\mathrm{CO}_{2}$ flux determined with the mini-towers $(\mathrm{n}=3)$ and that determined from soil water $(\mathrm{n}=3)$ were significantly different $(\mathrm{t}$-test, $\alpha=0.05)$.

\begin{tabular}{cccc}
\hline Date & Method & Site 1 & Site 2 \\
\hline 2 June 2003 & Mini-tower \#1 & $27.32 \pm 0.65(10,0.94)$ & $25.83 \pm 2.28(10,0.75)$ \\
2 June 2003 & Mini-tower \#2 & $27.91 \pm 0.98(10,0.98)$ & $29.24 \pm 0.87(10,0.96)$ \\
2 June 2003 & Mini-tower \#3 & $28.97 \pm 0.63(10,0.93)$ & $24.33 \pm 1.96(10,0.89)$ \\
2 June 2003 & Mean Mini-tower & $28.07 \pm 1.33$ & $26.47 \pm 3.13$ \\
2 June 2003 & Chamber & $34.06^{1}, 36.59^{2}, 38.72^{3}$ & $31.44^{1}, 34.22^{2}, 36.15^{3}$ \\
2 June 2003 & Soil CO & $31.00 \pm 0.00^{4}$ & $28.49 \pm 0.10^{4}$ \\
2 June 2003 & Soil Water & $31.88 \pm 0.08^{5}$ & $28.78 \pm 0.30^{5}$ \\
& & & \\
23 June 2003 & Mini-tower \#1 & $27.68 \pm 0.99(11,0.94)$ & $29.52 \pm 1.61(11,0.81)$ \\
23 June 2003 & Mini-tower \#2 & $28.92 \pm 0.52(11,0.98)$ & $27.53 \pm 1.29(11,0.97)$ \\
23 June 2003 & Mini-tower \#3 & $26.00 \pm 1.19(11,0.93)$ & $30.68 \pm 1.13(11,0.88)$ \\
23 June 2003 & Mean Mini-tower & $27.52 \pm 1.63$ & $29.25 \pm 2.35$ \\
23 June 2003 & Chamber & $32.78^{1}, 35.84^{2}, 36.87^{3}$ & $32.07^{1}, 35.01^{2}, 36.70^{3}$ \\
23 June 2003 & Soil CO & $25.20 \pm 0.00^{4}$ & $25.37 \pm 0.80^{4}$ \\
23 June 2003 & Soil Water & $24.92 \pm 0.30^{5}$ & $25.89 \pm 0.19^{5}$ \\
\hline
\end{tabular}

\subsection{Stable isotope analyses}

The ${ }^{18} \mathrm{O}$ and ${ }^{13} \mathrm{C}$ of $\mathrm{CO}_{2}$ for samples collected along the mini-towers and from the flux chambers were determined with a GC-IRMS (Gas Chromatograph: Hewlett Packard 5890 Series II, Isotope Ratio Mass Spectrometer: Finnigan Delta $\mathrm{S}$ ) operating in continuous flow mode. We applied a simple modification to a commercially available GC-IRMS for rapid and precise determination of stable isotopes of $\mathrm{CO}_{2}$ and $\mathrm{CO}_{2}$ concentrations. For a full description of the method see Mortazavi and Chanton (2000b). The $\mathrm{CO}_{2}$ concentrations from the soil $\mathrm{CO}_{2}$ flux chambers and the mini-towers were determined from the $\mathrm{CO}_{2}$ voltages obtained from the GC-IRMS (Mortazavi and Chanton, 2002b). Soil $\mathrm{CO}_{2}^{18} \mathrm{O}$ and ${ }^{13} \mathrm{C}$ were determined by direct injection of $0.2 \mathrm{ml}$ samples into the GC-IRMS. Soil $\mathrm{CO}_{2}$ concentrations were determined with a LI-COR 6200 (LI-COR Inc., Lincoln, Neb) according to the procedures described by Davidson and Trumbore (1995).

Water was extracted by cryogenic vacuum distillation from soil samples according to the procedures described by Ehleringer et al. (2000). A sub-sample of the extracted water $(0.5 \mathrm{ml})$ was equilibrated in a vial with $1 \% \mathrm{CO}_{2}$ headspace, and the ${ }^{18} \mathrm{O}$ of the headspace was analyzed after $48 \mathrm{~h}$ of incubation at $25^{\circ} \mathrm{C}$ for ${ }^{18} \mathrm{O}$ on the GC-IRMS by direct injection of $0.2 \mathrm{ml}$ of the headspace $\mathrm{CO}_{2}$ (Socki et al., 1992).

Soil samples were dried at $60^{\circ} \mathrm{C}$ to constant mass and roots were removed. Root free soil samples were then ground with a pestle and mortar. Samples were acidified (0.5 N HCL, for $24 \mathrm{~h}$ ) to remove carbonates (Rask and Schoenau, 1993). Samples were thoroughly washed with distilled water and dried to constant mass and ground with a pestle and mortar. Subsamples were analyzed for ${ }^{13} \mathrm{C}$ in duplicate on a $\mathrm{CHN}$ analyzer coupled to the IRMS.

Isotopic ratio data are presented in the $\delta$ notation, and are reported relative to $\mathrm{PDB}$ for $\delta^{13} \mathrm{C}$ and SMOW for $\delta^{18} \mathrm{O}$. External precision for isotopic measurements was \pm 0.2 based on repeated measurements of laboratory-working standards.

\subsection{Statistical considerations}

The isotopic composition of soil respired $\mathrm{CO}_{2}$ was determined with application of Keeling plots to the mini-tower and chamber $\mathrm{CO}_{2}$ concentrations and isotopic ratios. The ${ }^{13} \mathrm{C}$ of soil-respired $\mathrm{CO}_{2}$ from soil $\mathrm{CO}_{2}$ was determined by subtracting the $4.4 \%$ diffusional fractionation factor (Cerling et al., 1991) from the intercept of soil $\mathrm{CO}_{2}$ Keeling plots. We used a Model II regression (geometric mean regression, Sokal and Rohlf, 1981) to estimate the intercept of the Keeling plots. The standard error of the intercept of a model I regression is used to approximate the error estimate for the model II intercept (Sokal and Rohlf, 1981; Pataki et al., 2003). 
Table 2. The $\delta^{18} \mathrm{O}\left(\%\right.$ ) of $\mathrm{CO}_{2}$ at equilibrium with surficial soil water (0-2 cm depth) and soil water at 10-12 cm depth. The error corresponds to the standard deviation of triplicate soil water samples. * For comparison the measured value of soil $\delta^{18} \mathrm{CO}_{2}$ collected at $10 \mathrm{~cm}$ is also shown (mean $\pm 1 / 2$ range of duplicate measurements).

\begin{tabular}{ccccc}
\hline Date & \multicolumn{2}{c}{ Site 1 } & \multicolumn{2}{c}{ Site 2 } \\
\hline \multirow{2}{*}{ 2 June 2003 } & $0-2 \mathrm{~cm}$ & $10-12 \mathrm{~cm}$ & $0-2 \mathrm{~cm}$ & $10-12 \mathrm{~cm}$ \\
& $41.29 \pm 0.30$ & $40.69 \pm 0.08$ & $40.64 \pm 0.40$ & $37.58 \pm 0.30$ \\
23 June 2003 & $35.93 \pm 0.60$ & $39.50 \pm 0.00^{*}$ & & $37.30 \pm 0.14^{*}$ \\
& & $34.00 \pm 0.00^{*}$ & $37.40 \pm 0.33$ & $34.69 \pm 0.19$ \\
& & & $34.17 \pm 0.79^{*}$ \\
\hline
\end{tabular}

\section{Results and discussion}

\section{1 ${ }^{18} \mathrm{O}$ of soil respired $\mathrm{CO}_{2}$}

$\mathrm{CO}_{2}$ concentration in the mini-tower profiles increased above background values by $82.6 \mathrm{ppm}$ at site 1 and by $56.7 \mathrm{ppm}$ on 2 June 2003 and by $104.8 \mathrm{ppm}$ at site 1 and by $59.4 \mathrm{ppm}$ at site 2 on 23 June 2003 (data not shown). The average $\mathrm{CO}_{2}$ concentration difference between the highest point in the mini tower sampled $(179 \mathrm{~cm})$ and the background was $18 \mathrm{ppm}$. With a $\mathrm{CO}_{2}$ diffusion coefficient of $0.16 \mathrm{~cm}^{2} \mathrm{~s}^{-1}$ (Massman, 1998), $\mathrm{CO}_{2}$ loss by diffusion from the top to the chamber was two orders of magnitude lower than $\mathrm{CO}_{2}$ addition by soil respiration $\left(4.47 \pm 1.41 \mu\right.$ mole $\left.^{-2} \mathrm{~s}^{-1}, \mathrm{n}=4\right)$. Therefore, the selective loss of the lighter isotopes of $\mathrm{CO}_{2}$ from the top by diffusion could be ignored.

The mini-tower ${ }^{18} \mathrm{O}$ Keeling plots were linear, highly significant $(p<0.01)$, and had $r^{2}$ values ranging from 0.81 to 0.96 (Fig. 2, Table 1). Mean $\delta^{18} \mathrm{CO}_{2}$ values for the two adjacent sites combined varied from $27.27 \% \circ \pm 1.89(\mathrm{n}=6,1 \mathrm{SD})$ to $28.39 \%$ $\pm 1.65(\mathrm{n}=6,1 \mathrm{SD})$ on 2 and 23 June 2003 , respectively. There were several per mil differences in the ${ }^{18} \mathrm{O}$ of soil $\mathrm{CO}_{2}$ efflux determined with the mini-towers within the confines of the chamber collar at each location (Table 1). This difference could reflect heterogeneity in soil water or differences in the effective diffusional fractionation factor associated with $\mathrm{CO}_{2}$ flux from the soil to the atmosphere.

In contrast to the mini-tower Keeling plots, there was significant curvature in the chamber ${ }^{18} \mathrm{O}$ Keeling plots during all sampling periods (Fig. 2c). Therefore, an alternative procedure was used to estimate the ${ }^{18} \mathrm{O}$ of $\mathrm{CO}_{2}$ added relative to background concentrations between time points. $\mathrm{CO}_{2}$ concentration at time $t(C t)$ is a combination of $\mathrm{CO}_{2}$ at time zero $(\mathrm{Co})$ to which a certain amount of $\mathrm{CO}_{2}$ has been added $(\mathrm{Ca})$ by respiration (Eq. 1). The isotopic composition of $\mathrm{CO}_{2}$ at time $t(\delta t)$ is a product of the combination of $C o \delta o$ and $C a \delta a$ (2).

$$
\begin{aligned}
& C t=C o+C a \\
& C t \delta t=C o \delta o+C a \delta a
\end{aligned}
$$
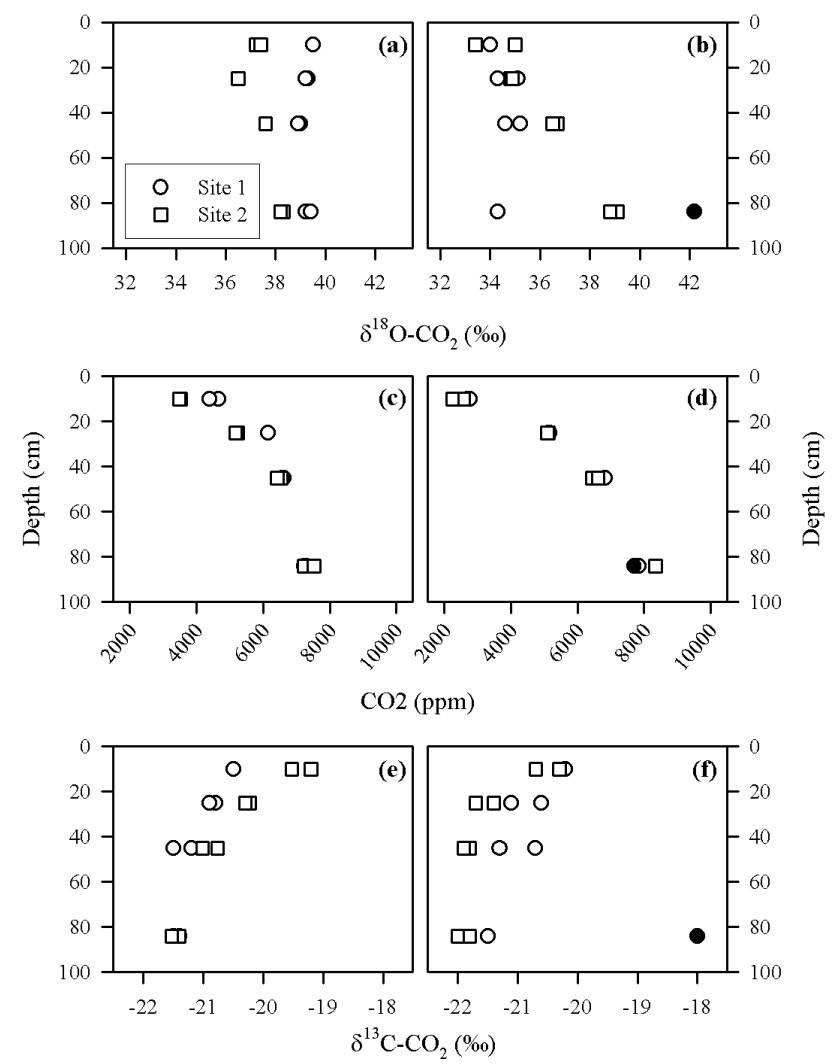

Fig. 3. Depth profiles of soil $\mathrm{CO}_{2}$ concentration measured on (a) 2 June 2003 and (b) 6/23/03. Depth profiles of soil $\delta^{18} \mathrm{O}-\mathrm{CO}_{2}$ (c) 2 June 2003 and (d) 23 June 2003. Depth profiles of soil ${ }^{13} \mathrm{C}-\mathrm{CO}_{2}$ on (e) 2 June 2003 and (f) 23 June 2003. The closed symbol was excluded form the regression of the ${ }^{13} \mathrm{C}$ Keeling plot (Table 3 ).

By measuring $C o, C t, \delta o$ and $\delta t, \delta a$ could be calculated between two time points. We calculated the ${ }^{18} \mathrm{O}$ of $\mathrm{CO}_{2}$ added by soil respiration between $0-7,7-14$ and 14-21 min in each chamber by using Eqs. (3) and (4) (Table 1). There was progressive enrichment in the ${ }^{18} \mathrm{O}$ of $\mathrm{CO}_{2}$ in the chamber headspace with time (Table 1). The ${ }^{18} \mathrm{O}$ of soil respired $\mathrm{CO}_{2}$ approached a value similar to that for $\mathrm{CO}_{2}$ in equilibrium with surface soil water (Table 2). The estimates from the chambers at even the shortest time interval $(7 \mathrm{~min})$ were enriched by several per mil relative to the mini-tower Keeling intercepts (Table 1).

Our time frame for chamber deployment is similar to that used by Lin et al. (1999), who used a mass balance equation to determine the ${ }^{18} \mathrm{O}$ of respired $\mathrm{CO}_{2}$ in a chamber headspace. The results (Table 1) indicate that the time frame considered for calculating the ${ }^{18} \mathrm{O}$ of respired $\mathrm{CO}_{2}$ from chamber data may be extremely important and highlight the influence of surface soil water on the estimate of the soil $\delta^{18} \mathrm{CO}_{2}$ efflux when using chambers. Flanagan et al. (1999) used chambers over short time frames during which the $\mathrm{CO}_{2}$ concentrations built up in the chamber headspace were sim- 
Table 3. $\delta^{13} \mathrm{C}(\% \circ)$ of soil $\mathrm{CO}_{2}$ efflux in Apalachicola National Forest. ${ }^{*} \mathrm{~A} 4.4 \%$ fractionation factor has been applied to the intercept of soil Keeling plot to determine the ${ }^{13} \mathrm{C}$ of soil $\mathrm{CO}_{2}$ efflux. ${ }^{* *}$ An outlier was excluded from the regression (see Fig. 3f). The numbers in the parentheses indicate the sample numbers used in the regression and the $\mathrm{r}^{2}$, respectively. Estimates of $\delta^{13} \mathrm{C}$ of soil $\mathrm{CO}_{2}$ flux determined with the chambers and the mini-towers $(n=3)$ were not different (t-test, $\alpha=0.05)$. The values for the mini-towers correspond to the intercept of the Keeling plot and the standard error. The standard errors were propagated for the calculation of mean for the mini-towers. With the exception of site 1 on 23 June 2003, estimates of the $\delta^{13} \mathrm{C}$ of soil $\mathrm{CO}_{2}$ flux determined with the chambers and with soil $\mathrm{CO}_{2} \mathrm{Keeling}$ plots were significantly different (t-test, $\alpha=0.05$ ).

\begin{tabular}{cccc}
\hline Date & Method & Site 1 & Site 2 \\
\hline 2 June 2003 & Mini-tower \#1 & $-27.16 \pm 1.17(10,0.96)$ & $-28.94 \pm 2.02(10,0.92)$ \\
2 June 2003 & Mini-tower \#2 & $-26.57 \pm 1.25(10,0.95)$ & $-24.04 \pm 0.83(10,0.98)$ \\
2 June 2003 & Mini-tower \#3 & $-26.54 \pm 1.16(10,0.96)$ & $-26.59 \pm 1.85(10,0.91)$ \\
2 June 2003 & Mean Mini-tower & $-26.76 \pm 2.07$ & $-26.52 \pm 2.86$ \\
2 June 2003 & Chamber & $-25.73 \pm 0.11(8,0.99)$ & $-25.89 \pm 0.30(8,0.99)$ \\
2 June 2003 & Soil CO 2 & $-27.19 \pm 0.34^{*}(8,0.82)$ & $-27.30 \pm 0.30(8,0.93)$ \\
& & & \\
23 June 2003 & Mini-tower \#1 & $-26.80 \pm 0.64(11,0.99)$ & $-26.30 \pm 1.14(11,0.96)$ \\
23 June 2003 & Mini-tower \#2 & $-25.45 \pm 0.50(11,0.99)$ & $-27.04 \pm 1.37(11,0.095)$ \\
23 June 2003 & Mini-tower \#3 & $-26.93 \pm 0.74(11,0.98)$ & $-23.60 \pm 0.91(11,0.96)$ \\
23 June 2003 & Mean Mini-tower & $-26.39 \pm 1.10$ & $-25.64 \pm 2.00$ \\
23 June 2003 & Chamber & $-26.05 \pm 0.18(8,0.99)$ & $-26.15 \pm 0.31(8,0.99)$ \\
23 June 2003 & Soil CO 2 & $-26.06 \pm 0.26^{*}(7,0.76)^{* *}$ & $-26.75 \pm 0.18(8,0.88)$ \\
\hline
\end{tabular}

ilar to $\mathrm{CO}_{2}$ increases in the mini-towers. That investigation was conducted in moss-covered boreal forest soil, and significant ${ }^{18} \mathrm{O}$ Keeling regressions were obtained. These authors, however, noted the importance of soil type on the ${ }^{18} \mathrm{O}$ of soil $\mathrm{CO}_{2}$ efflux.

The dominant factor controlling the ${ }^{18} \mathrm{O}$ of soil $\mathrm{CO}_{2}$ is equilibrium with soil water (Miller et al., 1999). However, in field studies both equilibrium and disequilibrium have been reported (Hesterberg and Siegenthaler, 1991; Amundson and Wang, 1995; Mortazavi and Chanton, 2002a). At our study site, the $\delta^{18} \mathrm{O}$ of soil $\mathrm{CO}_{2}$ was in close equilibrium with soil water ${ }^{18} \mathrm{O}$ at the $10-12 \mathrm{~cm}$ depth (Table 2 ).

We determined the ${ }^{18} \mathrm{O}$ of soil $\mathrm{CO}_{2}$ efflux by applying the diffusional fractionation factor to soil $\mathrm{CO}_{2}$ and to $\mathrm{CO}_{2}$ in oxygen isotopic equilibrium with soil water at $10 \mathrm{~cm}$ (Fig. 3). With the exception of site 2 on 23 June 2003, the estimates of soil $\delta^{18} \mathrm{O}-\mathrm{CO}_{2}$ flux were significantly different (t-test, $\alpha=0.05)$. Because detailed laboratory investigations are required to estimate the effective diffusional fractionation factor (Miller et al., 1999), we applied the maximum diffusional fractionation factor of $8.8 \%$. The ${ }^{18} \mathrm{O}$ of soil $\mathrm{CO}_{2}$ varied from $36.5 \%$ to $39.5 \%$ on 2 June 2003 and from 33.4 to 42.2\% on 23 June 2003 (Fig. 3). Estimates based on soil ${ }^{18} \mathrm{O}-\mathrm{CO}_{2}$ to which the fractionation factor has been applied to determine the ${ }^{18} \mathrm{O}$ of soil $\mathrm{CO}_{2}$ efflux bracketed the minitower values over the two sampling dates. Calculated values were enriched relative to the value measured with the minitowers on 2 June 2003 (Table 1). In contrast, on 23 June 2003, the ${ }^{18} \mathrm{O}$ of soil $\mathrm{CO}_{2}$ efflux estimated from soil $\mathrm{CO}_{2}$ was depleted relative to the estimates from the mini-towers (Table 1).
The discrepancy between the estimates of the isotopic composition of soil $\mathrm{CO}_{2}$ efflux based on soil $\mathrm{CO}_{2}$ from the mini-tower could result from several factors. The results from the analytical model developed by Stern et al. (1999) suggest that although ${ }^{18} \mathrm{O}$ of soil water dominated the ${ }^{18} \mathrm{O}$ of soil $\mathrm{CO}_{2}$, other factors such as soil respiration rates, respiration distribution within the soil, and advective transport contribute to the ${ }^{18} \mathrm{O}$ of soil $\mathrm{CO}_{2}$ efflux. Additionally, we applied the maximum diffusional fractionation factor, which could differ from the effective diffusional fractionation factor (Miller et al., 1999). The mini-tower approach provides an effective way to measure the ${ }^{18} \mathrm{O}$ of soil respired $\mathrm{CO}_{2}$ that does not involve application of assumed values for the fractionation factor.

\section{2 ${ }^{13} \mathrm{C}$ of soil respired $\mathrm{CO}_{2}$}

Examples from the mini-towers ${ }^{13} \mathrm{C}$ Keeling plots are shown in Fig. 2. ${ }^{13} \mathrm{C}$ Keeling plots from the mini-towers were highly significant (Table $3, r^{2}>0.91$ ). The $\delta^{13} \mathrm{C}$ of soil efflux determined with the mini towers were on 2 June $2003,-26.76 \% \circ \pm 2.07$ and $-26.52 \% \circ \pm 2.86$ at site 1 and 2 , respectively on 23 June 2003 were $-26.39 \%$ \pm 1.10 and $-25.64 \%$ \pm 2.00 at site 1 and 2 , respectively (Table 3 ). The standard errors of the Keeling intercepts of the mini-towers were greater than thse for the chambers (Table 3) due to the shorter duration of the mini-tower experiments ( $2 \mathrm{~min}$ ). The standard error of the Keeling intercepts declined with increasing range in $\mathrm{CO}_{2}$ concentrations for each set of flasks used in the regression (Fig. 4), a trend similar to that reported for canopy-scale Keeling plots (Bowling et al., 2003a; Pataki et al., 2003). 


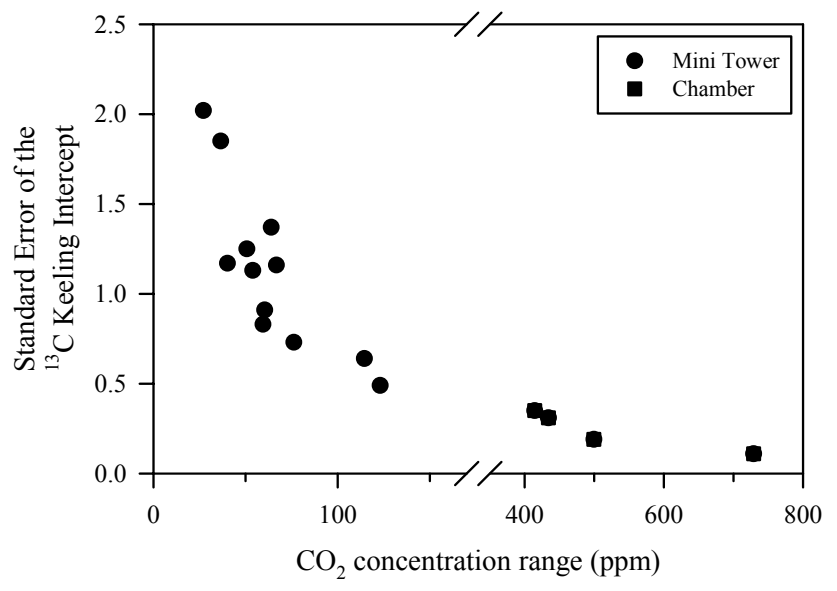

Fig. 4. Standard error of the $\delta^{13} \mathrm{C}$ Keeling intercepts as a function of the range in $\mathrm{CO}_{2}$ concentrations for each set of flasks used in the regression.

$\mathrm{CO}_{2}$ concentrations increased linearly during the chamber incubation on all attempts $\left(r^{2}=0.99\right.$, data not shown $)$ and were used to estimate soil respiration rates. Respiration rates were greater at site 1 compared to site 2 by $75 \%$ on 2 June 2003 and $21 \%$ and 23 June 2003 (data not shown). ${ }^{13} \mathrm{C}$ Keeling plots for the chamber data (Fig. 2, Table 3) were highly significant and had mean intercepts $(\mathrm{n}=2)$ of $-25.8 \%$ o and $-26.1 \%$ on 2 and 23 June 2003, respectively (Table 3). There was not a significant difference between the chamber based estimates of the $\delta^{13} \mathrm{C}$ of soil $\mathrm{CO}_{2}$ flux and the minitower estimates (t-test, $\alpha=0.05$ ).

The $\delta^{13} \mathrm{C}$ of soil $\mathrm{CO}_{2}$ efflux was also determined from soil $\mathrm{CO}_{2}$ profiles (Fig. 3). The range of $\mathrm{CO}_{2}$ concentrations varied from 3475 to $7530 \mathrm{ppm}$ on 2 June 2003 and from 2243 to $8345 \mathrm{ppm}$ on 23 June 2003 (Fig. 3). $\delta^{13} \mathrm{C}$ of soil $\mathrm{CO}_{2}$ decreased with increasing depth and varied from -19.2 to $-21.53 \%$ on 2 June 2003, and from -20.2 to $-22 \%$ on 23 June 2003 (Fig. 3). The ${ }^{13} \mathrm{C}$ Keeling plots were highly significant and yielded intercepts that varied by less than $0.7 \%$ o between the two sites during each visit (Table 3). There was a slight depletion in the ${ }^{13} \mathrm{C}$ of soil $\mathrm{CO}_{2}$ flux based on soil $\mathrm{CO}_{2}$ profiles on 23 June $2003,(-27.19 \% \circ \pm 0.34$ and $-27.30 \% \pm 0.30$ for site 1 and 2, respectively, Table 3) compared to 2 June $2003,(-26.06 \%$ \pm 0.26 and $-26.75 \%$ \pm 0.18 , for site 1 and 2, respectively, Table 3). The $\delta^{13} \mathrm{C}$ of soil $\mathrm{CO}_{2}$ flux determined from soil $\mathrm{CO}_{2}$ and that determined with the chambers were significantly different except at site 1 on 23 June 2003 (t-test, $\alpha=0.05$ ).

Mini-tower and chamber-based measurements of the $\delta^{13} \mathrm{C}$ of soil-respired $\mathrm{CO}_{2}$ have two advantages over estimates obtained from soil $\mathrm{CO}_{2}$ profiles. First, in contrast to estimates based on soil $\mathrm{CO}_{2}$ profiles that are generated from samples collected below the surface soil layer, mini-tower and chamber based estimates include the influence of litter respiration and the first few centimeters of the surface soil layer on the

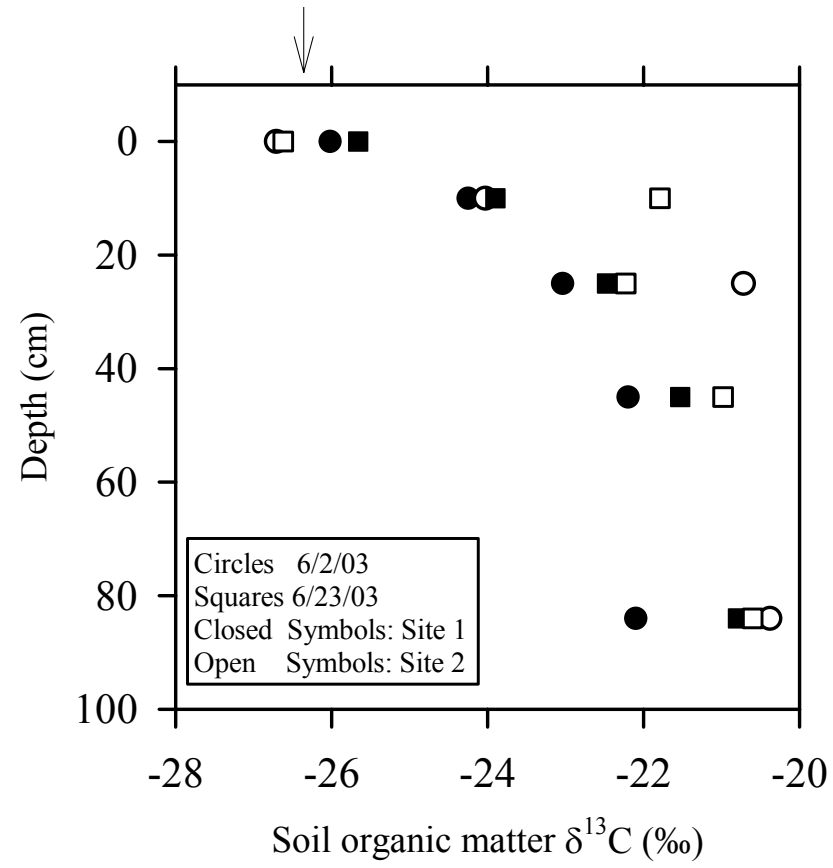

Fig. 5. The soil organic matter $\delta^{13} \mathrm{C}$ (root free soil samples). The arrow on the $\mathrm{x}$-axis indicates the mean $(\mathrm{n}=12)$ of the $\delta^{13} \mathrm{C}$ of soil $\mathrm{CO}_{2}$ flux determined from the mini-tower intercepts.

${ }^{13} \mathrm{C}$ of soil-respired $\mathrm{CO}_{2}$. Second, estimates of the $\delta^{13} \mathrm{C}$ of soil $\mathrm{CO}_{2}$ efflux based on the chambers and the mini-towers do not require the application of a fractionation factor for $\mathrm{CO}_{2}$ diffusion.

The $\delta^{13} \mathrm{C}$ of soil respired $\mathrm{CO}_{2}$ results from a combination of heterotrophic and autotrophic respiration. A profile of soil organic matter $\delta^{13} \mathrm{C}$ demonstrates a progressive enrichment in ${ }^{13} \mathrm{C}$ from a value of $-26.2 \% \circ \pm 0.5(1 \mathrm{SD}, \mathrm{n}=4)$ at the surface to a value of $-22.4 \% \circ \pm 2.8(1 \mathrm{SD}, \mathrm{n}=4)$ at $84 \mathrm{~cm}$ (Fig. 5). The mean value of the mini-tower Keeling intercepts $(-26.3 \%, \mathrm{n}=12)$ was remarkably close to the value of surface soil organic matter at this site (Fig. 5). While the $\delta^{13} \mathrm{C}$ associated with heterotrophic respiration is assumed to remain constant on seasonal time scales (Trumbore, 2000) that of autotrophic respiration will vary in response to changes in environmental conditions (Ekblad and Högberg, 2001). Therefore, despite the similarity in the ${ }^{13} \mathrm{C}$ of soil $\mathrm{CO}_{2}$ efflux and the $\delta^{13} \mathrm{C}$ of SOM (Fig. 5), the isotopic composition of soil organic matter is a poor predictor of the $\delta^{13} \mathrm{C}$ of soil respired $\mathrm{CO}_{2}$.

\section{Conclusions}

The data suggests that chamber and soil- $\mathrm{CO}_{2}$-based estimates for determining the $\delta^{18} \mathrm{O}$ of soil $\mathrm{CO}_{2}$ efflux are biased, and that the mini-towers provide effective means for estimating the $\delta^{18} \mathrm{O}$ of soil respired $\mathrm{CO}_{2}$. In contrast to the ${ }^{18} \mathrm{O}$ results, there were close agreements in the $\delta^{13} \mathrm{C}$ of soil 
$\mathrm{CO}_{2}$ efflux measured with the mini-towers and the chambers. Investigations using the $\delta^{18} \mathrm{O}$ of $\mathrm{CO}_{2}$ for partitioning ecosystem $\mathrm{CO}_{2}$ exchange into its components rely on accurate knowledge of the oxygen isotopic composition of soilrespired $\mathrm{CO}_{2}$. The mini-tower approach is cost-effective and provides a rapid means for determining the $\delta^{18} \mathrm{O}$ and $\delta^{13} \mathrm{C}$ of soil-respired $\mathrm{CO}_{2}$.

Acknowledgements. We would like to thank the assistance of $\mathrm{K}$. Peeler in the field. We would like to thank M. Smith and K. Bryan and three anonymous referees for comments on the manuscript. Financial support was provided by the Biological and Environmental Research (BER) Program, US Department of Energy, through the Southeast Regional Center (SERC) of the National Institute for Global Environmental Change (NIGEC), through the Terrestrial Carbon Processes Program (TCP, DE-FG02-00ER63016) and by the National Science Foundation (NSF \#0343604).

Edited by: S. V. Smith

\section{References}

Amundson, R. and Wang, Y.: Relationship between the oxygen isotopic composition of soil $\mathrm{CO}_{2}$ and water, In: Proceedings of a symposium on isotopes in water resources management, Vol. 1, International Atomic Energy Agency, Vienna, 315-332, 1995.

Bowling, D. R., McDowell, N. G., Welker, J. M., Bond, B. J., Law, B. E., and Ehleringer, J. R.: Oxygen isotope content of $\mathrm{CO}_{2}$ in nocturnal ecosystem respiration: 2. Shortterm dynamics of foliar and soil component fluxes in an oldgrowth ponderosa pine forest, Global Biogeoch. Cycles, 17, doi:10.1029/2003GB002082, 2003a.

Bowling, D. R., McDowell, N. G., Welker, J. M., Bond, B. J., Law, B. E., and Ehleringer, J. R.: Oxygen isotope content of $\mathrm{CO}_{2}$ in nocturnal ecosystem respiration: 1 . Observation in forests along a precipitation transect in Oregon, USA, Global Biogeoch. Cycles, 17, doi:10.1029/2003GB002081, 2003b.

Cerling, T. E., Solomon, D. K., Quade, J., and Bowman, J. R.: On the isotopic composition of carbon in soil carbon-dioxide, Geochim. Cosmochim. Acta, 55, 3403-3405, 1991.

Ciais, P., Denning, A. S., Tans, P. P., Berry, J. A., Randall, D. A., Collatz, G. J., Sellers, P. J., White, J. W. C., Trolier, M., Meijer, H. A. J., Francey, R. J., Monfrey, P., and Heimann, M.: A three-dimensional synthesis study of $\delta^{18} \mathrm{O}$ in atmospheric $\mathrm{CO}_{2}$ : 1. Surface fluxes, J. Geophys. Res., 102, 5857-5872, 1997.

Ciais, P. and Meijer, H. A. J.: The ${ }^{18} \mathrm{O} /{ }^{16} \mathrm{O}$ isotope ratio of atmospheric $\mathrm{CO}_{2}$ and its role in global carbon cycle research, In: Stable Isotopes-Integration of biological ecological and geochemical processes, edited by Griffiths, H., Bios Scientific, Oxford, 203-221, 1998.

Davidson, E. A. and Trumbore, S. E.: Gas diffusivity and production of $\mathrm{CO}_{2}$ in deep soils of the eastern Amazon, Tellus, 47, 550565, 1995.

Ehleringer, J. R., Roden, J., and Dawson, T. E.: Assessing ecosystem-level water relations through stable isotope ratio analyses, In: Methods in ecosystem science, edited by Sala, O. E., Jackson, G. A., Mooney, A. H., Howarth, R. W., Springer-Verlag, New York, 181-198, 2000.
Ekbald, A. and Högberg, P.: Natural abundance of ${ }^{13} \mathrm{C}$ in $\mathrm{CO}_{2}$ respired from forest soils reveals speed of link between tree photosynthesis and root respiration, Oecologia, 127, 305-308, 2001.

Fessenden, J. E. and Ehleringer, J. R.: Temporal variation in $\delta^{13} \mathrm{C}$ of ecosystem respiration in the Pacific Northwest: links to moisture stress, Oecologia, 136, 129-136, 2003.

Flanagan, L. B., Kubien, D. S., and Ehleringer, J. R.: Spatial and temporal variation in the carbon and oxygen stable isotope ratio of respired $\mathrm{CO}_{2}$ in a boreal forest ecosystem, Tellus, 51, 367384, 1999.

Francey, R. J., Tans, P. P., Allison, C. E., Enting, I. G., White, J. W. C., and Trolier, M.: Changes in oceanic and terrestrial carbon uptake since 1982, Nature, 373, 326-330, 1995.

Hesterberg, R. and Siegenthaler, U.: Production and stable isotopic composition $\mathrm{Of} \mathrm{CO}_{2}$ in a soil near Bern, Switzerland, Tellus, 43, 197-205, 1991.

Keeling, C. D., Whorf, T. P., Wahlen, M., and Vanderplicht, J.: Interannual extremes in the rate of rise of atmospheric carbon dioxide since 1980, Nature, 375, 666-670, 1995.

Lin, G. H., Ehleringer, J. R., Rygiewicz, P. T., Johnson, M. G., and Tingey, D. T.: Elevated $\mathrm{CO}_{2}$ and temperature impacts on different components of soil $\mathrm{CO}_{2}$ efflux in Douglas-fir terracosms, Glob. Change Biol., 5, 157-168, 1999.

Miller, J. B., Yakir, D., White, J. W. C., and Tans, P. P.: Measurements of ${ }^{18} \mathrm{O} /{ }^{16} \mathrm{O}$ in the soil-atmosphere $\mathrm{CO}_{2}$ flux, Global Biogeoch. Cycles, 13, 761-774, 1999.

Mills, G. A. and Urey, H. C.: The kinetics of isotope exchange between carbon dioxide, bicarbonate ion, carbonate ion and water, Journal of American Chemical Society, 62, 1019-1026, 1940.

Mortazavi, B., and Chanton, J. P.:Carbon isotopic discrimination and control of nighttime canopy $\delta^{18} \mathrm{O}-\mathrm{CO}_{2}$ in a pine forest in the Southeastern US, Global Biogeoch. Cycles, 16, doi:10.1029/2000GB001390, 2002a.

Mortazavi, B. and Chanton, J. P.: A rapid and precise technique for measuring $\delta^{13} \mathrm{CO}_{2}$ and $\delta^{18} \mathrm{CO}_{2}$ ratios at ambient $\mathrm{CO}_{2}$ concentrations for biological applications and the influence of container type and storage time on the sample isotope ratios, Rapid Commun. Mass Spectrom., 16, 1398-1403, 2002b.

Pataki, D. E., Ehleringer, J. R., Flanagan, L. B., Yakir, D., Bowling, D. R., Still, C. J., Buchmann, N., Kaplan, J. O., and Berry, J. A.: The application and interpretation of Keeling plots in terrestrial carbon cylcle research, Global Biogeoch. Cycles, 17, doi:10.1029/2001GB001850, 2003.

Peylin, P., Ciais, P., Denning, A. S., Tans, P. P., Berry, J. A., and White, J. W. C.: A 3-dimensional study of $\delta^{18} \mathrm{O}$ in atmospheric $\mathrm{CO}_{2}$ : contribution of different land ecosystems, Tellus, 51, 642, 1999.

Rask, H. M. and Schoenau, J. J.: ${ }^{13} \mathrm{C}$ natural abundance variations in carbonates and organic matter from boreal forest wetlands, Biogeochemistry, 22, 23-35, 1993.

Socki, R. A., Karlsson, H. R., and Gibson, E. K.: Extraction technique for the determination of oxygen-18 in water using preevacuated glass vials, Anal Chem, 64, 829-831, 1992.

Sokal, R. R. and Rohlf, F. J.: Biometry, W. H. Freeman and Company, New York, 859, 1981.

Stern, L., Baisden, W. T., and Amundson, R.: Processes controlling the oxygen isotope ratio of soil $\mathrm{CO}_{2}$ : Analytic and numerical modeling, Geochim. Cosmochim. Acta, 63, 799-814, 1999.

Stern, L. A., Amundson, R., and Baisden, W. T.: Influence of soils 
on oxygen isotope ratio of atmospheric $\mathrm{CO}_{2}$, Global Biogeoch. Cycles, 15, 753-759, 2001.

Tans, P. P.: Oxygen isotopic equilibrium between carbon dioxide and water in soils, Tellus, 50, 163-178, 1998.

Trumbore, S.: Age of soil organic matter and soil respiration: radiocarbon constraints on belowground C dynamics, Ecol. Appl., 10, 399-411, 2000.
Yakir, D. and Sternberg, L. D.: The use of stable isotopes to study ecosystem gas exchange, Oecologia, 123, 297-311, 2000.

Yakir, D. and Wang, X. F.: Fluxes of $\mathrm{CO}_{2}$ and water between terrestrial vegetation and the atmosphere estimated from isotope measurements, Nature, 380, 515-517, 1996. 


\title{
Use of Keeling plots to determine sources of dissolved organic carbon in nearshore and open ocean systems
}

\author{
Behzad Mortazavi ${ }^{1}$ and Jeffrey P. Chanton \\ Florida State University, Department of Oceanography, Tallahassee, Florida 32306-4320
}

\begin{abstract}
We apply a Keeling mixing model commonly used in atmospheric sciences to oceanic dissolved organic carbon (DOC) ${ }^{14} \mathrm{C}$ and concentrations to demonstrate that DOC distribution across spatial transects or depth profiles can be modeled as two-component mixtures; one component consists of an old refractory pool to which a newly synthesized component pool is added. We then use the Keeling approach to determine the $\Delta^{14} \mathrm{C}$ signature of excess DOC added to background concentrations in nearshore and open ocean systems. Our analysis indicates enrichment in ${ }^{14} \mathrm{C}$ of excess DOC in coastal waters relative to offshore waters, particularly in spring when river discharge increases. These findings are consistent with the export of ${ }^{14} \mathrm{C}$-enriched terrestrial DOC to the ocean and inconsistent with the idea of selective degradation of young terrestrial DOC in estuaries, resulting in export of old refractory component to the ocean. In the middle Atlantic Bight region, during the spring, excess DOC has a ${ }^{14} \mathrm{C}$ signature similar to that of DOC in the major rivers, whereas during the peak primary productivity of the summer season, excess DOC has a signature more similar to that of dissolved inorganic carbon. Variability in the $\Delta^{14} \mathrm{C}$ of excess DOC in the open ocean was lower than that of the coastal ocean. Minima in $\Delta^{14} \mathrm{C}$ values of excess DOC in the open ocean were measured during periods of high particulate organic matter (POC) flux, indicating that POC can interact with $\mathrm{DOC}$ and selectively remove ${ }^{14} \mathrm{C}$-enriched components from the surface ocean. The Keeling plot provides a powerful approach for determining the isotopic composition of excess DOC from an entire DOC profile or transect.
\end{abstract}

Dissolved organic carbon (DOC) constitutes the largest reduced carbon pool in the ocean $\left(1.7 \times 10^{18} \mathrm{~g} \mathrm{C}\right.$; Druffel et al. 1992). DOC in the ocean originates through primary production by cellular exudation, through viral lysis, and as a result of release during grazing by higher trophic levels. In the coastal ocean, rivers are a significant input source of DOC and globally deliver $0.25 \mathrm{Gt}$ C of DOC (Spitzy and Ittekkot 1991). A fraction of the DOC supplied to the water column is respired, a fraction is incorporated by the food web, and a fraction is mixed below the subsurface layer following the breakdown of water column stratification (Carlson et al. 1994). The incorporation of surface water DOC into the deep ocean effectively sequesters carbon in the oceans prior to its oxidation and return to the atmosphere after several mixing cycles within the world ocean (Druffel et al. 1992).

The radioisotopic form of $\mathrm{C},{ }^{14} \mathrm{C}$ with a half life of 5,730 $\mathrm{yr}$, has proven to be a useful tool for investigating sources, residence time, and transformations of inorganic and organic carbon pools in the ocean (Williams and Druffel 1987; Bauer

\footnotetext{
${ }^{1}$ Corresponding author (mortazavi@ocean.fsu.edu).
}

\section{Acknowledgments}

This research was supported by the Biological and Environmental Research program, U.S. Department of Energy, through the Terrestrial Carbon Processes Program (TCP, grant DE-FG02-00ER63016) and the National Science Foundation. Any opinions, findings, conclusions, or recommendations expressed in this publication are those of the authors and do not necessarily reflect the views of DOE. We thank Dr. E. Sherr, J. Winchester, R. Iverson, and two anonymous reviewers for helpful comments on the manuscript. The help of Rob Fowler, who provided statistical guidance, of the FSU Statistics Consulting Center is greatly appreciated. We thank Diane Pataki and Chun-Ta Lai for sharing the SAS codes. Finally, we express our appreciation to Ellen Druffel for reading an earlier draft of this manuscript. et al. 1992; Druffel et al. 1992). The ${ }^{14} \mathrm{C}$ of DOC has also been used to provide isotopic constraints on carbon exchange between different reservoirs (Bauer et al. 1995). Results from coastal regions, for example, indicate that ocean margins are a significant DOC source to the deep open ocean (Bauer and Druffel 1998). In deep ocean environments, ${ }^{14} \mathrm{C}$ of DOC and DOC concentration profiles in the sediments and overlying water provided evidence that deep ocean sediments are a source of relatively young DOC to the water column (Bauer et al. 1995).

According to the current paradigm, DOC in the ocean consists of an old or background refractory pool, with relatively constant concentration and $\Delta^{14} \mathrm{C}$ value as represented by the deep DOC pool, and a younger component present at varying concentrations in the upper ocean (Fig. 1A; Druffel et al. 1992; Carlson and Ducklow 1995; Cherrier et al. 1996; Bauer et al. 1998a). DOC at depth $z$ ([DOC]z) consists of an older background and relatively constant component ([DOC]b), to which an excess of more recently synthesized material is added ([DOC]xs):

$$
[\mathrm{DOC}] z=[\mathrm{DOC}] \mathrm{b}+[\mathrm{DOC}] \mathrm{xs}
$$

The goal of this paper is to introduce the oceanographic community to a model that can be used to determine the isotopic composition of DOC added in excess over background concentration ([DOC]xs in Eq. 1) that is based on concentration and isotopic measurements along a transect or profile. This model, developed in 1958 by Keeling (1958), is used by atmospheric chemists to determine the isotopic composition of excess $\mathrm{CO}_{2}$ added by nighttime respiration relative to the background tropospheric $\mathrm{CO}_{2}$ concentration (e.g., Mortazavi and Chanton 2002).

In forest canopies during the night, there is an increase in $\mathrm{CO}_{2}$ concentration relative to the background tropospheric 

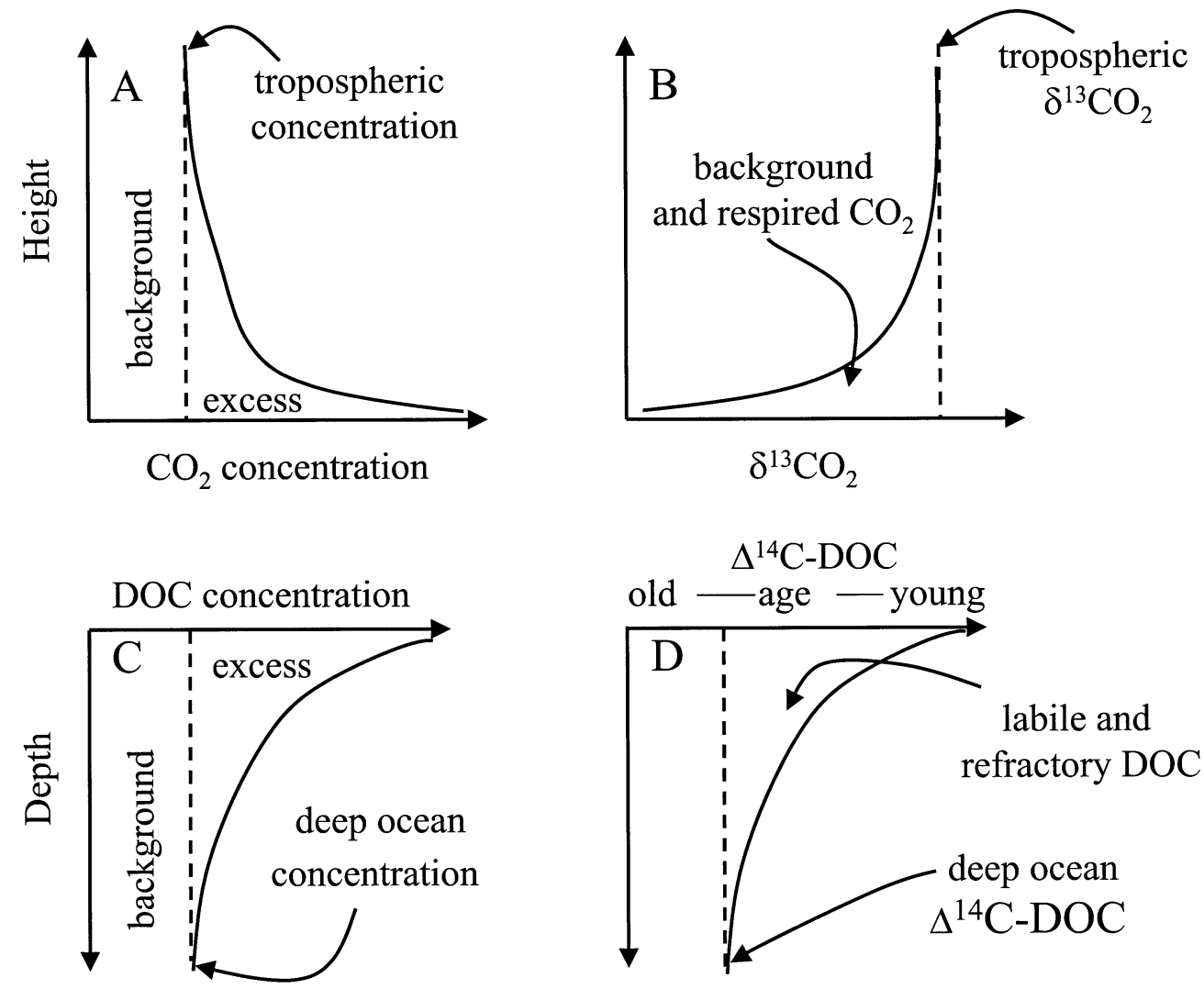

Fig. 1. Conceptual diagram of (A) $\mathrm{CO}_{2}$ buildup and (B) ${ }^{13} \mathrm{C}$ depletion in a forest canopy during the night. The depletion in ${ }^{13} \mathrm{C}$ results from addition of respired $\mathrm{CO}_{2}$ with a signature of $-27 \%$ o to a background tropospheric concentration of $\sim 370 \mathrm{ppm}$ and $\delta^{13} \mathrm{C}$ of $-8 \%$. An (C) oceanic DOC concentration and (D) ${ }^{14} \mathrm{C}$ profile shows an enrichment near the surface $(-100 \%$; Williams and Druffel 1987) because of the addition by the food web of young ${ }^{14} \mathrm{C}$-enriched DOC to a background refractory and ${ }^{14} \mathrm{C}$-depleted DOC (-500\%o; Williams and Druffel 1987) of relatively constant concentration (adapted from Cherrier et al. 1996).

concentration as a result of soil and foliage respiration (Fig. 1A). Concurrent with the increase in $\mathrm{CO}_{2}$ concentration, there is a depletion in the ${ }^{13} \mathrm{C}$ isotopic ratio of $\mathrm{CO}_{2}$ within the canopy because respiration adds $\mathrm{CO}_{2}$ with a signature of approximately $-27 \%$, less than a background tropospheric value of $-8 \%$ (Fig. 1A,B). A similar conceptual model can be used to describe oceanic DOC concentration and $\Delta^{14} \mathrm{C}$ profiles. A DOC profile shows an increase in concentration (Cherrier et al. 1996) and an enrichment in ${ }^{14} \mathrm{C}$ near-surface waters (Druffel et al. 1992) as a result of the addition by the food web of young DOC, enriched in ${ }^{14} \mathrm{C}$, over a background of old DOC depleted in ${ }^{14} \mathrm{C}$ that is relatively constant in concentration and ${ }^{14} \mathrm{C}$ content (Fig. 1C,D).

Our first objective was to test the hypothesis that the relation between oceanic $\Delta^{14} \mathrm{C}$ DOC and concentration can be described with a two-component mixing model, in which one component consists of background DOC of relatively constant concentration and ${ }^{14} \mathrm{C}$ content and a second component consists of a younger fraction (excess DOC) that is added to this background component. Although others have used a twocomponent model for discrete samples at unique depths (Druffel et al. 1992), our study differs in that we are expanding the approach across broad horizontal and vertical scales. Our analysis does not require prerequisite knowledge of the background DOC concentration and its isotopic ratio but, instead, can be used to resolve the isotopic composition of the excess DOC in a system. Our second objective was to use this model to contrast the spatial and temporal variability in the $\Delta^{14} \mathrm{C}$ of excess DOC at coastal and open ocean sites. Our approach toward accomplishing these goals was to (1) contrast oceanic DOC Keeling plots with data compiled from the literature on DOC concentrations and $\Delta^{14} \mathrm{C}$-DOC depth profiles or horizontal transects in nearshore and open ocean waters and (2) use the model to compare the $\Delta^{14} \mathrm{C}$ signature of excess DOC in coastal and open ocean waters.

\section{Methods}

The isotopic composition of DOC at depth $z\left(\Delta^{14} \mathrm{DOC} z\right)$ results from the relative contributions of background DOC with an isotopic value of $\Delta^{14} \mathrm{DOCb}$, and the newly added component (or a mixture of components added in constant proportions) with an isotopic value of $\Delta^{14} \mathrm{DOCxs}$.

$$
\begin{aligned}
([\mathrm{DOC}] z)\left(\Delta^{14} \mathrm{DOC} z\right)= & ([\mathrm{DOC}] \mathrm{b})\left(\Delta^{14} \mathrm{DOCb}\right) \\
& +([\mathrm{DOC}] \mathrm{xs})\left(\Delta^{14} \mathrm{DOCxs}\right)
\end{aligned}
$$


If a two-component mixing model is applicable, then by substituting $[\mathrm{DOC}] z-[\mathrm{DOC}] \mathrm{b}$ for [DOC]xs (Eq. 1) in Eq. 2 and by dividing both sides of Eq. 2 by [DOC] $z$, one finds that there should be a linear relation between $\Delta^{14} \mathrm{DOC} z$ and $1 /[\mathrm{DOC}] z$.

$$
\begin{aligned}
\Delta^{14} \mathrm{DOC} z= & (1 /[\mathrm{DOC}] z)\left([\mathrm{DOC}] \mathrm{b} \Delta^{14} \mathrm{DOCb}\right. \\
& \left.-[\mathrm{DOC}] \mathrm{b} \Delta^{14} \mathrm{DOCxs}\right) \\
& +\Delta^{14} \mathrm{DOCxs}
\end{aligned}
$$

The intercept $\left(\Delta^{14} \mathrm{DOCxs}\right)$ of a plot of $\Delta^{14} \mathrm{DOC} z$ as a function of $1 /[\mathrm{DOC}] z$ will correspond to the isotopic signature of excess DOC that has been added to background concentrations. The regression line will have a slope that is a composite of three parameters: [DOC]b, $\Delta^{14} \mathrm{DOCb}$, and $\Delta^{14}$ DOCxs. Because of a lack of specific knowledge of the background DOC concentration and isotopic composition, the slope does not provide any additional information. The regression analysis, however, is a powerful approach that can be used to determine $\Delta^{14} \mathrm{DOCxs}$. The great dynamic range in $\Delta^{14} \mathrm{C}$ of DOC, $-525 \%$ in deep ocean DOC (Bauer et al. $1998 a$ ), to $+257 \%$ in York River estuary (Raymond and Bauer 2001a), compared to the $2-3 \%$ range in $\Delta^{13} \mathrm{C}$ DOC (Bauer et al. 2002), provides a clear advantage for using ${ }^{14} \mathrm{C}$ instead of ${ }^{13} \mathrm{C}$ in Eq. 3. Admittedly, describing excess DOC as a single component is an oversimplification. However, if the individual components of excess DOC in a region or along a profile are supplied in relatively constant ratios, or as long as one component dominates within the timescale of mixing, we can obtain a linear fit to the data and calculate the $\Delta^{14} \mathrm{C}$ isotopic value of the DOC in excess of background values.

Statistical considerations-The assumptions associated with the standard linear regression (Model I) are violated when we assume that the independent variable $(1 /[\mathrm{DOC}] z)$ has no errors associated with it and is under the experimenter's control (Sokal and Rohlf 1981) and that the errors in the dependent variable $\left({ }^{14} \mathrm{DOC} z\right)$ are independent of errors in the dependent variable (Sokal and Rohlf 1981; Pataki et al. 2003). We, therefore, used a Model II regression (geometric mean regression, Sokal and Rohlf 1981) to estimate the intercept of the Keeling plots. The slope of the Model II regression is calculated as the slope of the Model I regression divided by the $R$ coefficient of the $X$ and $Y$ variables, and the standard error of the intercept of a Model I regression is used to approximate the error estimate for the Model II intercept (Sokal and Rohlf 1981; Pataki et al. 2003).

A Student's $t$-test (Sokal and Rohlf 1981) was used to test whether the intercepts of two Keeling plots were identical $\left(H_{0}\right)$ or significantly different $\left(H_{1}\right)$.

$$
t=(\mathrm{I} 1-\mathrm{I} 2) /\left[(\mathrm{SE} \mathrm{I} 1)^{2} / n 1+(\mathrm{SE} \mathrm{I} 2)^{2} / n 2\right]^{1 / 2}
$$

I1 and I2 are the intercepts of two Keeling plots, and (SE I1) and (SE I2) are the standard errors of the intercept for the two Keeling plots. The degrees of freedom will be $(n 1$ $+n 2-4$ ), where $n 1$ and $n 2$ are the sample sizes in the regression lines. At $P<0.05$, the null hypothesis was rejected in favor of $H_{1}$.

A Student's $t$-test (Sokal and Rohlf 1981) was used to test whether the intercept of a Keeling plot was identical $\left(H_{0}\right)$ or significantly different $\left(H_{1}\right)$ than mean $\Delta{ }^{14} \mathrm{C}$ of dissolved inorganic carbon (DIC).

$$
t=(\mathrm{I}-\mathrm{M}) /\left[(\mathrm{SE} \mathrm{I})^{2} / n 1+(\mathrm{SD} \mathrm{M})^{2} / n 2\right]^{1 / 2}
$$

$\mathrm{I}$ is the intercept of the Keeling plot and $\mathrm{M}$ is the mean value of the surface water $\Delta^{14} \mathrm{C}$ DIC and (SD M) is the standard deviation of the mean. The degrees of freedom will be $(n 1+$ $n 2-3$ ), where $n 1$ is the sample size used in the regression and $n 2$ is the sample size for $\Delta^{14} \mathrm{C}$ DIC values. At $P<0.05$, the null hypothesis was rejected in favor of $H_{1}$.

Results and discussion-The main objective of this research was to test the hypothesis that a two-component mixing model can be used to determine $\Delta^{14} \mathrm{C}$ in excess DOC across spatial transects and depth profiles in marine systems. Our approach toward evaluating this hypothesis was to examine DOC ${ }^{14} \mathrm{C}$ and concentration data to see whether they fit a two-component mixing model similar to that used by atmospheric chemists. The results of this analysis were then used to examine the temporal and spatial variability of $\Delta^{14} \mathrm{C}$ in excess DOC at coastal and open ocean sites. This is the first attempt to systematically compare $\Delta^{14} \mathrm{C}$ in excess DOC from all existing oceanic DOC profiles or transects.

Our approach to test the applicability of the Keeling plot approach for DOC in the ocean was to examine DOC Keeling plots for samples collected along a transect or a depth profile. If the DOC data can be treated as a background component of relatively constant concentrations and isotopic composition, to which a single component or multiple components in a constant blend is added, then a linear relation should exist between 1/DOC and $\Delta^{14} \mathrm{C}$ (Eq. 3), with an intercept that corresponds to the isotopic composition of excess DOC. The Keeling analyses yielded highly significant regressions for every profile, including coastal and open ocean samples $(0.82$ $<r^{2}<0.99$, e.g., Fig. 2; Table 1). Examples from the North Central Pacific, the Gulf of Mexico, and the North Atlantic (Fig. 2; Table 1) suggest that Keeling plots provide a useful means for determining the ${ }^{14} \mathrm{C}$ content of DOC in excess of the background concentrations from an entire data set compiled along a transect or a depth profile. The Keeling plot intercepts for the North Central Pacific, the Gulf of Mexico and the western North Atlantic (Fig. 2) were significantly different from each other at $P<0.05$.

Spatial and temporal variability of $\triangle^{14} \mathrm{C}$ in excess DOCCoastal ocean: The Keeling analysis for coastal transects off Delaware and Chesapeake Bay and the Cape Hatteras region (Transects 4, 5, and 6 from Bauer et al. 2002) show a clear temporal variability in the $\Delta^{14} \mathrm{C}$ signature of excess DOC for the spring and summer seasons (Table 1; Fig. 3). During the spring period of high river discharge, the $\Delta^{14} \mathrm{C}$ of excess DOC exceeded $\Delta^{14} \mathrm{C}$ DIC values. The largest deviations were measured at the outflow region of the Chesapeake and Delaware Bays. It is only during the summer months and at the station farthest from the river outflow (Transect 6, summer 96) that $\Delta^{14} \mathrm{C}$ values of excess DOC were similar to DIC values, indicating that excess DOC during this period predominantly resulted from in situ primary production. At all other times and locations in the Middle Atlantic Bight (MAB), $\Delta^{14} \mathrm{C}$ of 

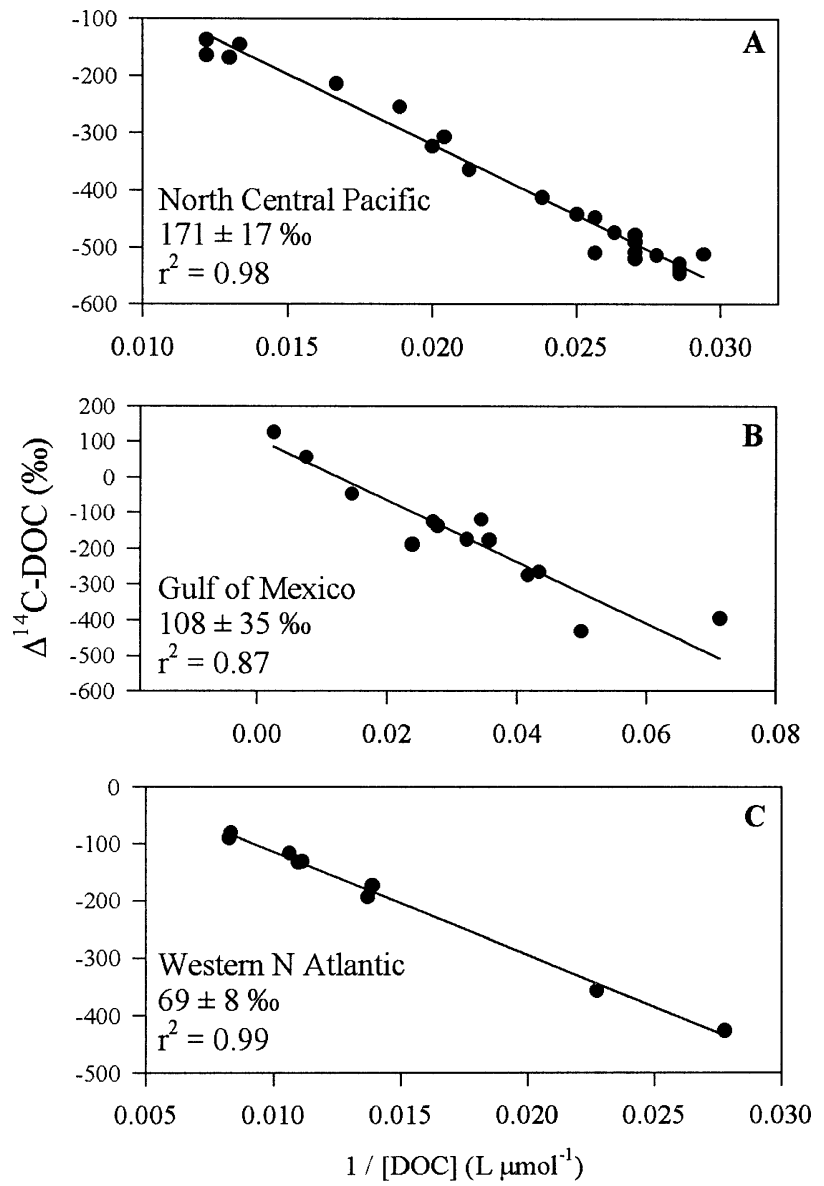

Fig. 2. Keeling plots for (A) the North Central Pacific (Druffel et al. 1992), (B) the Gulf of Mexico (Santschi et al. 1995), and (C) the western North Atlantic Transects 2 and 3 collected July 1996 (Bauer et al. 2002). A Model II regression was used to estimate the intercept of the regression line (see Methods). For each plot, the intercept $( \pm 1 \mathrm{SE})$ and the correlation coefficient is shown.

excess DOC and mean $\Delta^{14} \mathrm{C}$ DIC values were significantly different at the $\alpha=0.05$ level (Student's $t$-test).

Bauer et al. (2002) observed a positive shift in the $\Delta^{14} \mathrm{C}$ of total DOC by 20-133\%o from March to August 1996. They speculated that this enrichment might have resulted directly or indirectly from increased phytoplankton production during the summer season. The Keeling approach clearly highlights the temporal shift in the source of excess DOC between spring and summer seasons in the coastal regions of the north Atlantic (Fig. 3). During the summer, the higher DOC concentrations and younger $\Delta^{14} \mathrm{C}$ DOC values measured by Bauer et al. (2002) in the MAB associated with lower salinity waters would appear to be the result of riverine nutrient input to the MAB and stimulation of primary production, as observed by Lohrenz et al. (2002), rather than the result of DOC input from alluvial sources. Summer primary productivity in the MAB exceeds the spring rates by $60 \%$ (Lohrenz et al. 2002). The input of recently assimilated DOC to the water column was apparent at the southernmost portion of the MAB during summer 1996 , where $\Delta^{14} \mathrm{C}$ in excess DOC was similar to the mean $\Delta^{14} \mathrm{C}$ in water column DIC (Student's $t$-test, $P>0.05$; Fig. 3).
During the spring, excess DOC in the MAB region has ${ }^{14} \mathrm{C}$ values that are more similar to DOC from the York river estuary (208-257\%o, Raymond and Bauer 2001a), a major subestuary of the Chesapeake Bay, and indicates DOC accumulation in surface waters of decadal-aged material of presumably terrestrial/riverine origin. The Keeling analyses indicate that accumulation of young ${ }^{14} \mathrm{C}$-enriched DOC in the shelf from spring to summer resulted from increased phytoplankton production. The increase in DOC concentration and the ${ }^{14} \mathrm{C}$ enrichment of excess DOC during the summer was less than the ${ }^{14} \mathrm{C}$ enrichment of excess DOC in the spring (Fig. 3), when high river flow discharge exported terrestrial DOC to the MAB.

Our analysis agrees with that of Bauer et al. (2002), who suggested the contribution to shelf waters of ${ }^{14} \mathrm{C}$-enriched organic matter of terrestrial and riverine origin. We also agree with the hypothesis of Raymond and Bauer (2001b) that rivers discharging to the Atlantic Ocean export ${ }^{14} \mathrm{C}$-enriched terrestrial organic matter (Fig. 3). However, our analysis is not consistent with the Raymond and Bauer postulation that the young riverine DOC component can be selectively degraded and result in export of an older, more refractory component with an apparent age of 1,500 yr to the ocean (Raymond and Bauer 2001b). The $\Delta^{14} \mathrm{C}$ in excess DOC in the MAB has a modern signature that varies from $309 \%$ during the spring to $70 \%$ in the summer (Fig. 3).

The MAB receives freshwater from the Hudson, Delaware, and Chesapeake estuaries that carry high loads of DOC, and much of this DOC is of terrestrial origin, consisting of refractory organic matter that can be transported to the shelf region (Aluwihare et al. 2002). Less than 5\% of the DOC is believed to be imported from a combination of rivers, estuaries, atmospheric deposition, and sediment porewater flux, whereas the rest is supplied from George's Bank (Vlahos et al. 2002). Although these DOC mass balance calculations suggest that, on an annual time scale, only a minor fraction of total DOC is derived from rivers and estuaries, on a seasonal time scale, the $\Delta^{14} \mathrm{C}$ values of excess DOC suggest that, during spring, decadal-aged DOC can contribute significantly to the excess DOC accumulating in the surface waters of the MAB region (Table 1; Fig. 3).

There is an apparent accumulation both inshore and alongshelf of excess DOC produced in shelf waters, as well as discharged to the MAB from the dominant rivers and estuaries (Bauer et al. 2002; Vlahos et al. 2002). Mass balance calculations suggest that DOC in the MAB resulted in total export of between 18.7 and $19.6 \mathrm{Tg} \mathrm{C} \mathrm{yr}^{-1}$, and as much as $67 \%$ of this DOC appeared to be recycled material that is believed to be refractory (Vlahos et al. 2002). Because of the short residence time of the MAB region, 50-300 d (Wallace 1994), excess DOC during spring, with a riverine/estuarine $\Delta^{14} \mathrm{C}$ signature, is potentially available for export to the open ocean.

The Keeling model can also be applied to size-fractionated DOC. Santschi et al. (1995) determined the apparent ages of size-fractionated dissolved organic carbon for samples collected in the Gulf of Mexico (GOM) and the Cape Hatteras region. Their results indicated that the $1-\mathrm{kDa}$ to $0.2-\mu \mathrm{m}$ colloidal organic carbon size fraction (COC1) had an apparent age of 380-4,500 yr. The Keeling intercepts for the COC1 
Table 1. $\Delta^{14} \mathrm{C}$ in excess DOC determined from DOC transects or profiles in coastal regions and open ocean systems. The Keeling intercepts were determined with a Model II regression (see Methods). The number of samples in a transect or a profile used to determine the Keeling intercepts and the coefficient of determination for the regression is indicated $\left(n, r^{2}\right)$. The Gulf of Mexico and the Cape Hatteras Keeling intercepts were determined for the ultrafiltered DOC fraction (1 kDa to $0.2 \mu \mathrm{m})$. All others are for total DOC. Transect numbers

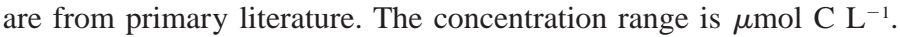

\begin{tabular}{|c|c|c|c|c|}
\hline & $\begin{array}{c}\text { Year } \\
\text { collected }\end{array}$ & $\begin{array}{l}\text { Keeling } \\
\text { intercept }\end{array}$ & $\begin{array}{c}\text { Concentration } \\
\text { range }\end{array}$ & $\begin{array}{c}\delta^{14} \mathrm{C} \\
\text { range }\end{array}$ \\
\hline \multicolumn{5}{|l|}{ Bauer et al. 2002} \\
\hline NW Atlantic $\mathrm{N}$ transect & Apr 94 & $98 \pm 36(8,0.95)$ & $46-102$ & $-442,-160$ \\
\hline NW Atlantic C transect & Apr 94 & $309 \pm 35(7,0.98)$ & $51-115$ & $-451,-39$ \\
\hline NW Atlantic $S$ transect & Apr 94 & $119 \pm 53(7,0.93)$ & $50-112$ & $-438,-98$ \\
\hline North Atlantic transect $1+2$ & Mar 96 & $136 \pm 19(8,0.99)$ & $49-85$ & $-418,-172$ \\
\hline North Atlantic transect 3 & Mar 96 & $95 \pm 38(10,0.92)$ & $47-107$ & $-418,-120$ \\
\hline North Atlantic transect 4 & Mar 96 & $222 \pm 88(7,0.85)$ & $94-42$ & $-420,-117$ \\
\hline North Atlantic transect 5 & Mar 96 & $210 \pm 59(8,0.91)$ & $46-126$ & $-432,-77$ \\
\hline North Atlantic transect 6 & Mar 96 & $154 \pm 74(7,0.85)$ & $38-102$ & $-401,-85$ \\
\hline North Atlantic transect 1 & Aug 96 & $155 \pm 24(8,0.98)$ & $41-75$ & $-414,-159$ \\
\hline North Atlantic transect $2+3$ & Aug 96 & $69 \pm 8(9,0.99)$ & $36-121$ & $-427,-80$ \\
\hline North Atlantic transect 4 & Aug 96 & $84 \pm 19(8,0.99)$ & $39-119$ & $-404,-69$ \\
\hline North Atlantic transect 5 & Aug 96 & $83 \pm 16(9,0.99)$ & $39-156$ & $-408,-29$ \\
\hline North Atlantic transect 6 & Aug 96 & $70 \pm 17(7,0.99)$ & $38-90$ & $-420,-138$ \\
\hline \multicolumn{5}{|l|}{ Santschi et al. 1995} \\
\hline Gulf of Mexico & 1992-1993 & $108 \pm 35(13,0.87)$ & $14-404$ & $-432,-126$ \\
\hline N Atlantic Cape Hatteras & Jun 93 & $141 \pm 34(6,0.99)$ & $20-44$ & $-427,-101$ \\
\hline \multicolumn{5}{|l|}{ Bauer et al. $1998 a$} \\
\hline NE Pacific Station M & Jul 91 & $-13 \pm 72(9,0.86)$ & $33-62$ & $-558,-302$ \\
\hline NE Pacific Station M & Feb 92 & $105 \pm 56(9,0.93)$ & $38-70$ & $-559,-287$ \\
\hline NE Pacific Station M & Jun 92 & $152 \pm 61(10,0.93)$ & $38-72$ & $-573,-238$ \\
\hline NE Pacific Station M & Oct 92 & $111 \pm 33(9,0.98)$ & $37-72$ & $-550,-250$ \\
\hline NE Pacific Station M & Feb 92 & $124 \pm 52(6,0.97)$ & $37-67$ & $-546,-244$ \\
\hline NE Pacific Station M & Jul 93 & $31 \pm 33(5,0.99)$ & $36-74$ & $-543,-257$ \\
\hline \multicolumn{5}{|l|}{ Bauer et al. $1998 b$} \\
\hline NE Pacific Station M & Jun 95 & $44 \pm 61(11,0.88)$ & $36-72$ & $-568,-275$ \\
\hline NE Pacific Continental Rise & Jun 95 & $71 \pm 55(8,0.94)$ & $35-65$ & $-568,-287$ \\
\hline NE Pacific Upper Slope & Jun 95 & $163 \pm 104(5,0.90)$ & $43-56$ & $-466,-324$ \\
\hline \multicolumn{5}{|l|}{ Druffel et al. 1992} \\
\hline North Central Pacific & Jun 87 & $162 \pm 39(19,0.92)$ & $34-72$ & $-536,-179$ \\
\hline Sargasso Sea & May 91 & $78 \pm 39(23,0.82)$ & $40-75$ & $-414,-210$ \\
\hline
\end{tabular}

size fractions, however, indicate that in both the GOM and the Cape Hatteras region, excess COC1 has a $\Delta^{14} \mathrm{C}$ signature similar to that of the $\Delta^{14} \mathrm{C}$ of DIC (Fig. 3), thus indicating that excess $\mathrm{COC} 1$, despite the century-old apparent age of the COC1 total pool, is of contemporary origin. This result suggests that the dominant mechanism for formation of new COC1 is through assimilation of new carbon rather than the breakdown of "aged" organic matter.

Open ocean: The variability in $\Delta^{14} \mathrm{C}$ in excess DOC at the open ocean sites was lower than the variability at the coastal sites (Table 1; Fig. 3). In the open ocean, the greatest variability in water column $\Delta^{14} \mathrm{C}$ in DOC occurs at depths above $700 \mathrm{~m}$, where the seasonal effects of primary production and remineralization are greatest (Bauer et al. 1998a). In the open ocean, the major source of DOC to the deep ocean derives from soluble or solubilized forms of organic matter produced in the euphotic zone by living organisms. This is in contrast to the coastal sites that also receive temporally varying inputs of DOC from rivers and estuaries.
Minima in the Keeling intercepts at Sta. M in the North Central Pacific were measured during intense periods of particulate organic matter (POC) flux in July 1991 and July 1993 (Bauer et al. 1998a). The seasonal shift in the isotopic composition of excess DOC could result from its interaction with the POC through adsorption and removal of certain components of DOC (Druffel et al. 1992; Bauer et al. 1998a). Minimum surface DOC concentrations at Sta. M were measured during a period when sinking POC flux was maximal (Bauer et al. 1998a). $\Delta^{14} \mathrm{C}$ values of subsurface POC were $20-30 \%$ o enriched during the high-POC flux period (Druffel et al. 1996). The Keeling approach also suggests that the interaction between DOC and POC selectively removes DOC enriched in ${ }^{14} \mathrm{C}$ during periods of high POC flux (Druffel et al. 1996; Bauer et al. 1998a). Another source of variability of $\Delta^{14} \mathrm{C}$ in DOC at the open ocean site can be observed along an offshore-inshore Pacific ocean transect (Fig. 3). The $\Delta^{14} \mathrm{C}-\mathrm{DOC}$ enrichment near the coast indicates a possible terrestrial DOC contribution to the nearshore marine environment, similar to Atlantic observations. 


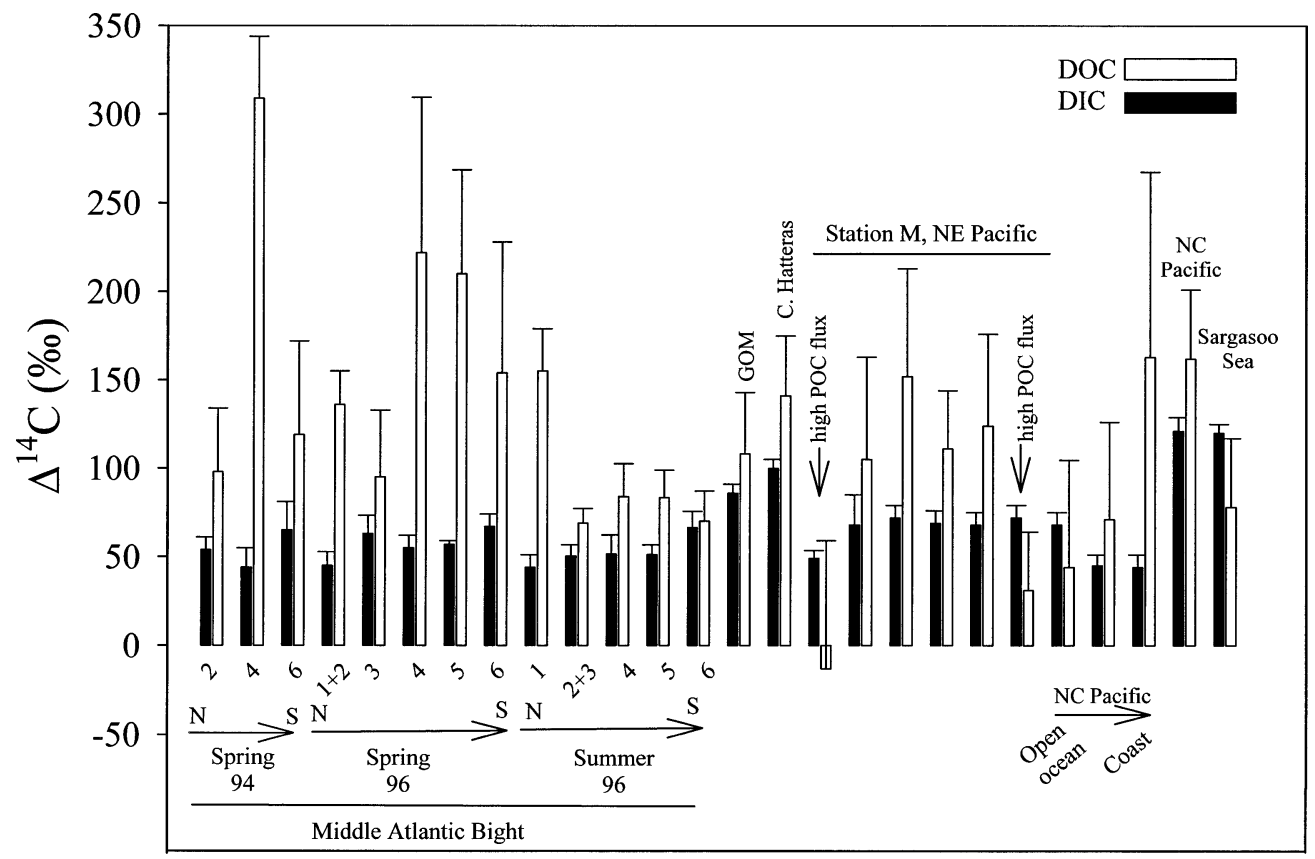

Fig. 3. $\quad \Delta^{14} \mathrm{C}$ in excess DOC and associated error determined from the intercept of the Keeling plots and the $\Delta^{14} \mathrm{C}$ of DIC for the Gulf of Mexico (GOM), Cape Hatteras, the Middle Atlantic Bight (MAB, numbers refer to the transect locations from Bauer et al. [2002], Transect 1 is in the northern $\mathrm{MAB}$, whereas Transect 6 is located in the southern portion of the MAB, and Transects 4 and 5 correspond to the outflow region of the Delaware and Chesapeake Bays), Sta. M in the NE Pacific, an offshore-inshore transect in the North Central Pacific, the North Central Pacific, and the Sargasso Sea. The Gulf of Mexico and Cape Hatteras samples correspond to the ultrafiltered ( $1 \mathrm{kDa}-0.2 \mu \mathrm{m})$ fraction of DOC. DIC values for the GOM and Cape Hatteras are from Santschi et al. (1995) and Severinghaus et al. (1996). DIC values for the MAB region are from Bauer et al. (2002). DIC values for Sta. M are from Masiello et al. (1998). DIC values for the transect from the open ocean to the coast in the North Central Pacific region are from Bauer et al. (1998b). DIC values for the North Central Pacific and Sargasso Sea profiles are from Druffel et al. (1992). There was a significant difference $(P<0.05)$ between the intercept of the Keeling plots and mean $\Delta^{14} \mathrm{C}$ DIC values at all the MAB stations, except at Region 6 during summer 1996. Notice the spatial and temporal variability in ${ }^{14} \mathrm{C}$ of excess DOC and the deviation from the $\Delta^{14} \mathrm{C}$ of DIC during high river flow periods in the MAB region. The intercept of the Keeling plots and mean $\Delta^{14} \mathrm{C}$ DIC values in the North Central Pacific and the Sargasso Sea were significantly different $(P<0.05)$. We could not test for significant differences between the intercept of the Keeling plots and mean $\Delta^{14} \mathrm{C}$ DIC values in the GOM, Cape Hatteras, Sta. M, NE Pacific, and open ocean to coast transect in the North Central Pacific because only few samples were collected for determination of the $\Delta^{14} \mathrm{C}$ in DIC. The error bars for $\Delta^{14} \mathrm{C}$ DIC values correspond to the standard deviation of replicate samples or to the analytical precision, in case replicate samples were not collected.

\section{Summary}

Stable isotopes of $\mathrm{C}, \mathrm{N}$, and $\mathrm{S}$ have been used to constrain sources of organic matter in nearshore marine environments (e.g., Chanton and Lewis 2002). The prerequisite associated with these models is the knowledge of the isotopic value for "end-member" components. The Keeling plot approach uses a linear regression on measured variables to determine the end-member isotopic value of excess DOC relative to the background value. The large dynamic range in $\Delta^{14} \mathrm{C}$ values in naturally occurring organic matter reservoirs allows ${ }^{14} \mathrm{C}$ to be used as a sensitive source indicator. In the future, by increasing the sampling frequency, the standard error of the intercept of the Keeling plots and the standard deviation of the estimates of mean surface water $\Delta^{14} \mathrm{C}$ DIC can be reduced, which will lead to more robust statistics.
Results indicate a high degree of variability of $\Delta^{14} \mathrm{C}$ in DOC available for export from the margins to the open ocean or from the surface to the subsurface layers following the breakdown of water column stratification. The Keeling approach offers a powerful and consistent approach for determining and quantitatively comparing the isotopic value of the excess DOC and the associated error term by considering an entire DOC transect or profile.

\section{References}

Aluwihare, L. I., D. J. Repeta, And R. F. Chen. 2002. Chemical composition and cycling of dissolved organic matter in the mid-Atlantic Bight. Deep-Sea Res. 49: 4421-4437.

Bauer, J. E., AND E. R. M. DrufFel. 1998. Ocean margins as a significant source of organic matter to the deep open ocean. Nature 392: 482-485. 
P. M. Williams, And E. R. M. Druffel. $1992 .{ }^{14} \mathrm{C}$ activity of dissolved organic carbon fractions in the north-central $\mathrm{Pa}-$ cific and Sargasso Sea. Nature 357: 667-670.

, C. E. Reimers, E. R. M. Druffel, and P. M. Williams. 1995. Isotopic constraints on carbon exchange between deep ocean sediments and sea water. Nature 373: 686-689.

, E. R. M. Druffel, P. M. Williams, D. M. Wolgast, and S. GRIFFIN. 1998a. Temporal variability in dissolved organic carbon and radiocarbon in the eastern North Pacific Ocean. J Geophys Res., C 103: 2867-2881.

, D. M. Wolgast, S. Griffin, And C. A. MasielLO. 1998b. Distributions of dissolved organic and inorganic carbon and radiocarbon in the eastern North Pacific continental margin. Deep-Sea Res. 45: 689-713.

$\longrightarrow, \longrightarrow$, AND $\longrightarrow$. 2002. Temporal and regional variability in sources and cycling of DOC and POC in the northwest Atlantic continental shelf and slope. Deep-Sea Res. 49: 4387-4419.

CARlson, C. A., AND H. W. DucKlow. 1995. Dissolved organic carbon in the upper ocean of the central equatorial Pacific Ocean, 1992: Daily and finescale vertical variations. Deep-Sea Res. 42: 639-656.

$\longrightarrow$, AND A. F. Michaels. 1994. Annual flux of dissolved organic carbon from the euphotic zone in the northwestern Sargasso Sea. Nature 371: 405-408.

Chanton, J. P., AND F. G. LewIs. 2002. Examination of coupling between primary and secondary production in a river-dominated estuary: Apalachicola Bay, Florida, U.S.A. Limnol. Oceanogr. 47: 683-697.

Cherrier, J., J. E. BAuer, And E. R. M. Druffel. 1996. Utilization and turnover of labile dissolved organic matter by bacterial heterotrophs in eastern north Pacific surface waters. Mar. Ecol. Prog. Ser. 139: 267-279.

Druffel, E. R. M., P. M. Williams, J. E. Bauer, and J. R. Ertel. 1992. Cycling of dissolved and particulate organic matter in the open ocean. J. Geophys. Res. 97: 15,639-15,659.

- J. E. Bauer, P. M. Williams, S. Griffin, And D. M. Wolgast. 1996. Seasonal variability of particulate organic radiocarbon in the northeast Pacific Ocean. J. Geophys. Res. 101: 20,543-20,552.

KeELING, C. D. 1958. The concentration and isotopic abundances of atmospheric carbon dioxide in rural areas. Geochim. Cosmochim. Acta 13: 322-334.

Lohrenz, S. E., D. G. Redalje, P. G. Verity, C. N. FlagG, and
K. V. Matulewski. 2002. Primary production on the continental shelf off Cape Hatteras, North Carolina. Deep-Sea Res. 49: 4479-4509.

Masiello, C. A., E. R. M. Druffel, and J. E. Bauer. 1998. Physical controls on dissolved inorganic radiocarbon variability in the California Current. Deep-Sea Res. 45: 617-642.

Mortazavi, B., and J. P. Chanton. 2002. Carbon isotopic discrimination and control of nighttime canopy $\delta^{18} \mathrm{O}-\mathrm{CO}_{2}$ in a pine forest in the southeastern US. Glob. Biogeochem. Cycles 16: $10.1029 / 2000 G B 001390$.

PATAKI, D. E., AND OTHERS. 2003. The application and interpretation of Keeling plots in terrestrial carbon cylcle research. Glob. Biogeochem. Cycles 17: 10.1029/2001GB001850.

RAYMOND, P. A., AND J. E. BAUER. 2001a. DOC cycling in a temperate estuary: A mass balance approach using natural ${ }^{14} \mathrm{C}$ and ${ }^{13} \mathrm{C}$ isotopes. Limnol. Oceanogr. 46: 655-667.

— AND —. 2001b. Riverine export of aged terrestrial organic matter to the North Atlantic Ocean. Nature 409: 497500.

SANTSCHI, P. H. AND OTHERS. 1995. Isotopic evidence for the contemporary origin of high-molecular weight organic matter in oceanic environments. Geochim. Cosmochim. Acta 59: 625631.

Severinghaus, J. P., W. S. Broecker, T. H. Peng, and G. Bonani. 1996. Transect along $24^{\circ} \mathrm{N}$ latitude of ${ }^{14} \mathrm{C}$ in dissolved inorganic carbon in the subtropical North Atlantic ocean. Radiocarbon 38: 407-414.

Sokal, R. R., And F. J. Rohlf. 1981. Biometry. WH Freeman.

SpITZY, A., AND V. ITtEKKоT. 1991. Dissolved and particulate organic matter in rivers, p. 5-17. In R. F. C. Mantoura, J. M. Martin, and R. Wollast [eds.], Ocean margin processes in global change. Wiley.

Vlahos, P., R. F. Chen, And D. J. RePetA. 2002. Dissolved organic carbon in the mid-Atlantic Bight. Deep-Sea Res. 49: 43694385.

WALlaCE, D. W. R. 1994. Anthropogenic chlorofluoromethanes and seasonal mixing rates in the Middle Atlantic Bight. Deep-Sea Res. 41: 307-324.

Williams, P. M., AND E. R. M. DRufFel. 1987. Radiocarbon in dissolved organic matter in the central North Pacific Ocean. Nature 330: 246-248.

Received: 12 November 2002 Accepted: 12 August 2003 Amended: 15 August 2003 